\title{
Reinforcements, production techniques and property analysis of AA7075 matrix composites - a critical review
}

\author{
Sowrabh B.S., Gurumurthy B.M., Shivaprakash Y.M. , and Sathya Shankara Sharma \\ Department of Mechanical and Manufacturing Engineering, Manipal Institute of Technology, Manipal Academy of Higher \\ Education, Manipal, Karnataka, India
}

Received: 13 September 2021 / Accepted: 11 November 2021

\begin{abstract}
Aluminium alloy based metal matrix composites are being extensively used in the aerospace, automobile, defense, marine and electronic industries owing to their excellent strength, high resistance to wear, corrosion and better thermal stability. Many investigators have explored different aluminium alloy series composites, like heat treatable AA2024, AA6061 and AA7075 since the properties of these matrix alloys can be easily tailor made to suite specific application due to easy processability and heat treatability. AA7075 alloy matrix is predominantly being used, as it exhibits high ultimate tensile strength, resistance to corrosion and fatigue in the group. In the current review work, attention is focused to present types of reinforcing materials used, benefits of reinforcement hybridization, methods employed for composite production and critical property analysis, with conclusions of experimentation and the suggested prospective applications of AA7075 composites. Due to good castability and moldability variety of processing techniques in solid, semisolid and liquid states are possible. As matrix alloy, low processing temperature, ability to accommodate reinforcements and adoptability to different reinforcing techniques, it is easy to obtain optimal properties as per the application. AA7075 with small addition of copper is paved the path in the field of electronic and military applications due to high thermal and electrical conductance. Even pure metal addition \& magnesium with copper facilitate good weldability, plasticity and corrosion resistance. Due to the flexibility in accommodating carbide and oxide compound reinforcements in the matrix, this matrix composite widens versatility limit due to excellent hardness and wear resistance. CNT and graphite reinforcements to this aluminium series matrix are marked as ultra-high precision components in defense field.
\end{abstract}

Keywords: AA7075 alloy / reinforcements / processability / property and metal matrix composites

\section{Introduction}

It is the never ending dream of the materials engineer to discover materials with specific characteristics like, light weight, high formability, high strength and hardness at affordable cost. Accordingly, aluminium matrix composites have become versatile materials to satisfy the requirements of the applications in present industries as per the posing demands of present market. One of the recognizable factors in these composites is property tailorability by suitable heat treatment. Because of flexibility to alter existing properties, aluminium based composites are most preferred for its usage in aerospace, automotive, sporting goods, defense, electronic, thermal management and in general engineering industries [1-3]. In the past few decades many investigations were undertaken

\footnotetext{
* e-mail: prakash.ym@manipal.edu
}

on different series of aluminium alloy for developing the composite materials with an intention of exploring new possible application areas. In the present paper, an effort is made to review the research undertaken in recent past on AA7075 based composites. This work is believed to support many researchers for further exploring the potential areas of investigation on these composites.

\section{AA7075 as a matrix material}

AA7075 (7xxx grade aluminium) alloys are most favorable for applications due to high specific tensile strength, versatility and performability [4]. This series of aluminium alloys are the most attractive materials for aerospace, marine and automobile applications because of their high ultimate tensile strength to weight ratio, good corrosion resistance and excellent workability [5-9]. They are also employed in structures of missile, structural parts of 
Table 1. Usage limitations of AA7075.

\begin{tabular}{ll}
\hline Type of limitation & References \\
\hline $\begin{array}{l}\text { Difficulty in joining by conventional fusion-welding techniques } \\
\text { Involves complicated process for welding and it is highly reactive to caustic acids, }\end{array}$ & {$[37]$} \\
water, and oxygen. & {$[31]$} \\
Poor tribological properties & {$[4,14,20,25,38-42]$} \\
Fatigue cracks due to cyclic loading is one of the most important issues in these & {$[43-45]$} \\
alloys & {$[18]$} \\
Poor mechanical and the tribological properties at high temperatures & {$[19]$} \\
Reduced strength and hardness due to residual coarse and insoluble secondary & {$[46]$} \\
phases & {$[23]$} \\
Lower compression strength and hardness & \\
Formation of built-up-edge to lower machinability and reduce tool life &
\end{tabular}

automotive and aircraft, railroad cars, sports industry and other high performance structural applications because of formability and specific strength [4,10-13]

Among all other series of aluminium alloys, AA7075 (a typical Al-Zn-Mg-Cu alloy) is much explored. This is the commonly preferred alloy of $7 \mathrm{xxx}$ series as it provides a good combination of properties like, very high strength, higher toughness, high thermal and electrical conductance, high abrasion and wear resistance, damage resilience at elevated and cryogenic temperatures, good fatigue strength, creep resistance, highest failure elongation. Hence, is preferred in submarines, ships, prosthetic devices, trucks, rail vehicles, machinery, pressure vessels, aerospace, aircraft (lower drag brace landing gears, ventral fins, and helicopter blades), electronic applications, military and automobile sectors (piston, brake calipers, wheels, and rocker arms) [14-36].

Despite many favorable properties of AA7075 alloy, it also suffers with some limitations that hinders its usage in some applications. The summary of these limitations which needs to be addressed to improve the application range of this alloy is listed in Table 1 .

\section{Reinforcements with AA7075}

Aluminium alloys in general are less hard and have low wear resistance, which hinder their adaptability in high performance mechanical and tribological applications. In order to overcome these problems hard reinforcements are dispersed in the matrix for achieving superior strength to weight ratio, wear resistance, stiffness, resistance to fatigue and higher temperature performance. Hence nowadays the composites containing hard particles are gaining importance $[1,47]$. Also to improve quality, nature sustainability and bring down the cost of composites, investigations are centered to use reinforcements for higher matrix wettability and dispersivity [48].

Morphologically the reinforcements can be continuous or discontinuous. Continuous fibers in composite provide good strengthening in a specific direction and discontinuous fibers are attractive because of their comparatively low cost and isotropic properties [49]. With these advantages of discontinuous reinforcements, many such reinforcements are tried in aluminium alloys. Accordingly, various types of particulate reinforcements found place in AA7075 matrix as shown in Figure 1. The summary on type, size and quantity of reinforcements employed by different researchers is presented in Table 2.

\section{Techniques used for producing AA7075 MMCs}

\subsection{Solid state processing techniques}

\subsubsection{Powder metallurgy (PM)}

PM consists of wet mixing of the powders of matrix and reinforcements followed by cold isostatic pressing, degassing, sintering, and hot isostatic pressing [52,55]. Few researchers [85] have developed blended powder semisolid forming (BPSF) which besides providing the benefits of conventional semisolid powder metallurgy, also changes the quantity and size of each element in a compound. This process is done in three main stages, in first stage, the homogeneous dispersion of elemental powders takes place, in second stage mechanical alloying is carried out, it elevates the elemental state powders temperature and allows for solid diffusion, and in third stage semisolid compaction is done which fills the free spaces in between the solid particles with liquid phase.

Due to the application of higher pressure during compaction there was a better liquid phase filling of the voids, which resulted in improvement of density and hardness of composites. Compressive strength was improved by $93 \%$ for 20 microns AA7075 matrix particles with incorporation of $20 \%$ vol. 45 microns $\mathrm{B}_{4} \mathrm{C}$ because of homogeneous distribution of particles which is evident from Figure 2.

In order to obtain a clean metallurgical interface between the reinforcement particles and matrix as well as grain refinement, powders can be cryomilled followed by consolidation through plasma activated sintering (PAS) to prevent any undesirable phases. Cryomilling, involves milling in liquid nitrogen with stearic acid as a surfactant [86]. After milling the mixture of matrix and reinforcement 


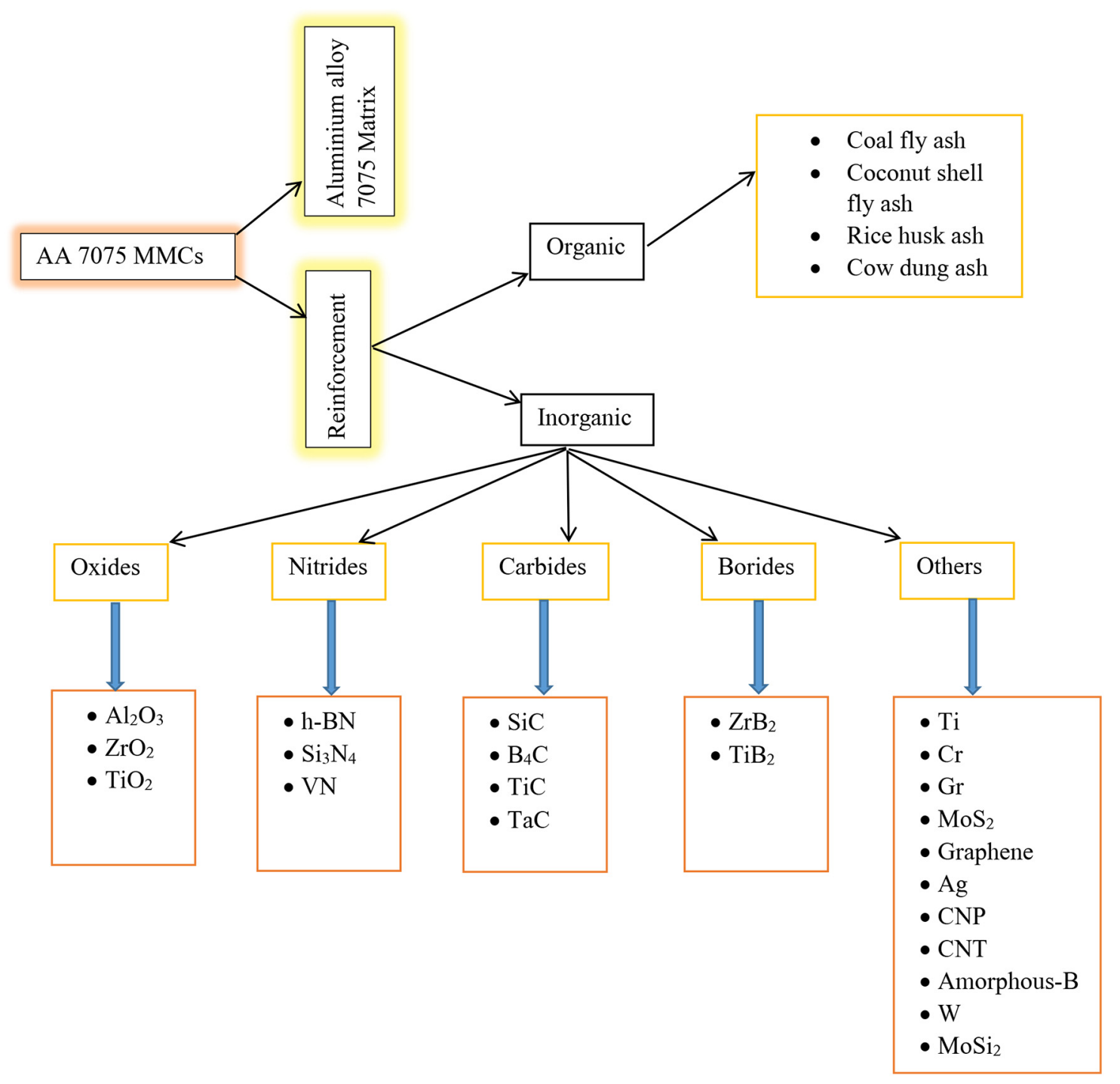

Fig. 1. Different reinforcements adapted to produce AA7075 MMCs.

powder, it is poured into a graphite mold without prepressing [9]. Powders are then consolidated by plasma activated sintering to produce cylindrical composite specimens. For the production of composites, mechanical ball milling of powders was carried out in an argon atmosphere, then mixed powders were subjected to hot press sintering followed by extrusion [5,77,96,104]. In another route, after milling process, the mixed powders were packed in a graphite mold and then cold pressed. Subsequently, the graphite mold was fixed in vacuum hot press sintering furnace to produce the composite compacts $[18,103]$. As alternate process, the authors [12] produced composite by first milling the matrix and reinforcements followed by encapsulating in pure $\mathrm{Cu}$ container with subsequent pressing by equal channel angular pressing (ECAP) route. Investigators even tried vacuum impregnation and explosive pressing for producing AA7075/h-BN and AA7075/B amorphous composites respectively [78]. During the vacuum impregnation the alloy was slightly over heated for enhancing the wettability with BN particles (upto $40 \%$ vol.). Also these researchers reported that method of explosive pressing consists of affecting a pressure impulse of shock wave to finally obtain the composites. Literature shows that very few researchers have tried these routes for producing MMCs.

\subsubsection{Friction stir processing/welding (FSP/FSW)}

FSP method is beneficial in enhancing the surface properties of material. This process uses a hard and rotating tool that penetrates into work piece and traversing in forward direction. By this approach, reinforcing particles penetrate the metal surface at a certain depth. The process set up is as shown in Figure 3(i) [65]. It is an alternative to FSW, FSP is developed to overcome the challenges related to uniform distribution of nano reinforcements in aluminium matrix. The experimental setup used by the researchers [23] is as shown in Figure 3(ii). Also, researchers $[4,40,90,91]$ have adapted FSP in their studies for 
Table 2. Details on type of reinforcement, quantity and production approach adapted by different researchers.

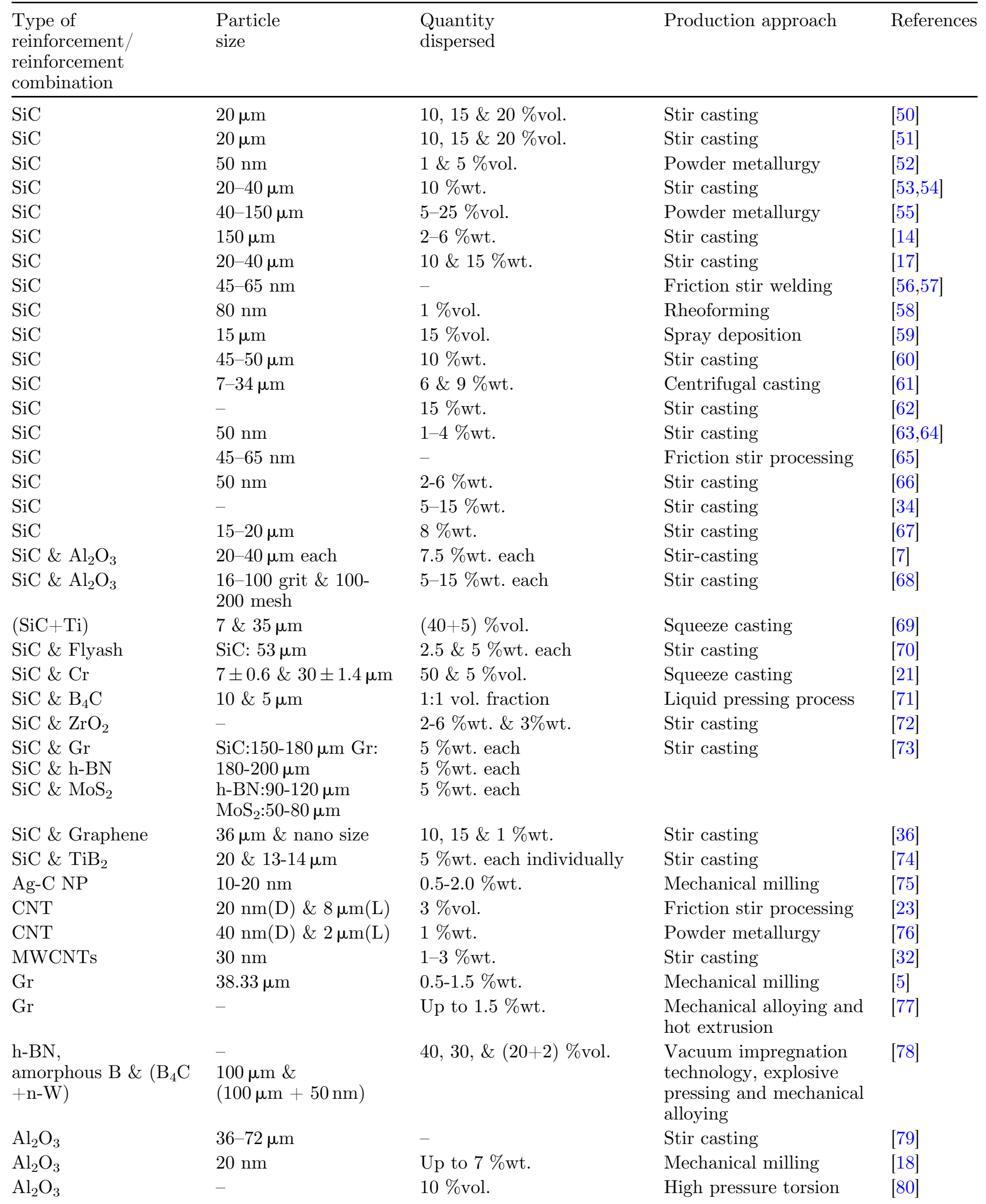


Table 2. (continued).

\begin{tabular}{|c|c|c|c|c|}
\hline $\begin{array}{l}\text { Type of } \\
\text { reinforcement/ } \\
\text { reinforcement } \\
\text { combination }\end{array}$ & $\begin{array}{l}\text { Particle } \\
\text { size }\end{array}$ & $\begin{array}{l}\text { Quantity } \\
\text { dispersed }\end{array}$ & Production approach & References \\
\hline $\mathrm{Al}_{2} \mathrm{O}_{3}$ & Nano size & $1.5 \%$ wt. & Casting & [81] \\
\hline $\mathrm{Al}_{2} \mathrm{O}_{3}$ & $30-50 \mu \mathrm{m}$ & $2.5 \%$ wt. & Squeeze casting & {$[82]$} \\
\hline $\mathrm{Al}_{2} \mathrm{O}_{3}$ & $20-30 \mathrm{~nm}$ & $1-4 \%$ wt. & Stir casting & {$[29]$} \\
\hline $\mathrm{Al}_{2} \mathrm{O}_{3} \&$ graphite & -- & $2-8 \& 5 \%$ wt. & Stir casting & [83] \\
\hline $\mathrm{Al}_{2} \mathrm{O}_{3} \&$ h-BN & $30-50 \& 80-100 \mathrm{~nm}$ & $1 \& 0.5 \%$ wt. & Stir casting & {$[21]$} \\
\hline $\mathrm{Al}_{2} \mathrm{O}_{3} \& \mathrm{~h}-\mathrm{BN}$ & $5-10 \mu \mathrm{m}$ each & $2.5 \& 5 \%$ wt. each & Two step stir casting & [84] \\
\hline $\mathrm{Al}_{2} \mathrm{O}_{3} \&$ Flyash & - & $5 \& 10 \%$ wt. each & Stir casting & [28] \\
\hline $\mathrm{Al}_{2} \mathrm{O}_{3} \& \mathrm{SiC}$ & $20-30 \& 50 \mathrm{~nm}$ & 1-4 \%wt. combined & Stir casting & {$[30]$} \\
\hline $\mathrm{Al}_{2} \mathrm{O}_{3} \& \mathrm{SiC}$ & $3 \& 2 \mu \mathrm{m}$ & $1.8-7.5 \& 1.5-6 \%$ wt. & Friction stir processing & [40] \\
\hline $\mathrm{TiO}_{2}$ & $30-40 \mathrm{~nm}$ & $10-20 \%$ wt. & Mechanical milling & {$[12]$} \\
\hline $\mathrm{B}_{4} \mathrm{C}$ & $<10 \mu \mathrm{m}$ & Up to $12.5 \%$ wt. & Mechanical milling & [9] \\
\hline $\mathrm{B}_{4} \mathrm{C}$ & $15-18 \mu \mathrm{m}$ & - & Friction stir processing & [4] \\
\hline $\mathrm{B}_{4} \mathrm{C}$ & - & $15 \%$ wt. & Stir casting & {$[62]$} \\
\hline $\mathrm{B}_{4} \mathrm{C}$ & $45 \mu \mathrm{m}$ & 5-20\%vol. & Powder metallurgy & [85] \\
\hline $\mathrm{B}_{4} \mathrm{C}$ & $2 \mu \mathrm{m}$ & $20 \%$ wt. & Powder metallurgy & {$[86]$} \\
\hline $\mathrm{B}_{4} \mathrm{C}$ & $2.031 \mu \mathrm{m}$ & $7.5 \%$ wt. & $\begin{array}{l}\text { Plasma activated } \\
\text { sintering }\end{array}$ & [8] \\
\hline $\begin{array}{l}\mathrm{B}_{4} \mathrm{C} \& \text { Coconut shell } \\
\text { flyash }\end{array}$ & $75 \& 62 \mu \mathrm{m}$ & Up to $12 \& 3 \%$ wt. & Stir casting & {$[87]$} \\
\hline $\mathrm{B}_{4} \mathrm{C} \&$ Rice husk ash & $50 \& 62 \mu \mathrm{m}$ & $5 \& 3.5 \%$ wt. & Stir casting & {$[46]$} \\
\hline $\mathrm{B}_{4} \mathrm{C} \& \mathrm{MoS}_{2}$ & $10 \& 2 \mu \mathrm{m}$ & $4-12 \& 3 \%$ wt. & Stir casting & {$[25]$} \\
\hline $\mathrm{B}_{4} \mathrm{C} \&$ Flyash & $3-10 \mu \mathrm{m}$ each & $2-8 \& 2 \%$ wt. & Stir casting & {$[26]$} \\
\hline $\mathrm{B}_{4} \mathrm{C} \&$ Flyash & $150 \mu \mathrm{m}$ each & $1-4 \& 6-9 \%$ wt. & Stir casting & {$[88]$} \\
\hline $\mathrm{B}_{4} \mathrm{C} \& \mathrm{BN}$ & $1 \mu \mathrm{m}$ each & 3-9 \& $3 \%$ wt. & Stir casting & [89] \\
\hline $\mathrm{B}_{4} \mathrm{C} \& \mathrm{BN}$ & $1 \& 10 \mu \mathrm{m}$ & 3-9 \& 3\%wt. & Stir casting & [42] \\
\hline $\mathrm{B}_{4} \mathrm{C} \&$ Cow dung ash & $50-70 \& 40-60 \mu \mathrm{m}$ & $2.5-7.5 \%$ wt. each & Two step stir casting & {$[33]$} \\
\hline $\mathrm{ZrO}_{2}$ & $110 \mathrm{~nm}$ & $2 \& 5 \%$ wt. & Mechanical milling & [90] \\
\hline $\mathrm{ZrB}_{2} \& \mathrm{hBN}$ & $5 \& 3 \mu \mathrm{m}$ & $5 \%$ wt. each & $\begin{array}{l}\text { Stir-squeeze cast } \\
\text { technique }\end{array}$ & [39] \\
\hline $\mathrm{TiC}$ & $20 \mathrm{~nm}$ & $2 \%$ wt. & Friction stir processing & [91] \\
\hline $\mathrm{TiC}$ & $3.5 \mu \mathrm{m}$ & $2-6 \%$ vol. & Friction stir processing & [92] \\
\hline $\mathrm{TiC}$ & - & $2.5-7.5 \%$ wt. & Stir casting & {$[27]$} \\
\hline $\mathrm{TiC}$ & $6-8 \mu \mathrm{m}$ & - & $\begin{array}{l}\text { laser shock peening } \\
\text { (LSP) and friction stir } \\
\text { welding (FSW) }\end{array}$ & [93] \\
\hline $\mathrm{TiC} \& \mathrm{~B}_{4} \mathrm{C}$ & $5-15 \& 10-25 \mu \mathrm{m}$ & 5-10 \%vol. each & Two step stir casting & [94] \\
\hline $\mathrm{TiC} \& \mathrm{MoS}_{2}$ & Micro particles & $2,4 \& 2 \%$ wt. & Stir casting & {$[95]$} \\
\hline Ti \& Gr & $\leq 80 \& \leq 150 \mu \mathrm{m}$ & $3,5,6 \& 8 \%$ wt. combined & In situ process & {$[96]$} \\
\hline $\mathrm{TiB}_{2}$ & - & $15 \%$ wt. & Stir casting & [62] \\
\hline $\mathrm{TiB}_{2}$ & $20-500 \mathrm{~nm}$ & $6 \%$ wt. & In-situ process & [97] \\
\hline $\mathrm{TiB}_{2}$ & Nano size & $1.5 \%$ vol. & In-situ process & [98] \\
\hline $\mathrm{TiB}_{2}$ & - & $6 \%$ wt. & In-situ process & [99] \\
\hline $\mathrm{TiB}_{2} \& \mathrm{Gr}$ & - & $1.5-6 \& 1 \% \mathrm{wt}$. & In-situ process & {$[24]$} \\
\hline $\mathrm{Si}_{3} \mathrm{~N}_{4}$ & - & $2-8 \%$ wt. & Stir casting & {$[100]$} \\
\hline $\mathrm{Si}_{3} \mathrm{~N}_{4}$ & $10-40 \mu \mathrm{m}$ & $4,8 \& 12 \%$ wt. & Stir casting & {$[101]$} \\
\hline $\mathrm{Si}_{3} \mathrm{~N}_{4}$ & - & $4,8 \& 12 \%$ wt. & Stir casting & {$[102]$} \\
\hline
\end{tabular}


Table 2. (continued).

\begin{tabular}{lllll}
\hline $\begin{array}{l}\text { Type of } \\
\text { reinforcement/ } \\
\text { reinforcement } \\
\text { combination }\end{array}$ & $\begin{array}{l}\text { Particle } \\
\text { size }\end{array}$ & $\begin{array}{l}\text { Quantity } \\
\text { dispersed }\end{array}$ & Production approach & References \\
\hline $\mathrm{TaC}, \mathrm{Si}_{3} \mathrm{~N}_{4}, \mathrm{Ti}$ & $200-250 \mathrm{~nm}, 20 \mu \mathrm{m}$, & $\begin{array}{l}0.25-1,2-8 \% \mathrm{wt} . \\
0.5-2 \% \mathrm{wt} .\end{array}$ & Stir casting & {$[35]$} \\
$\mathrm{MoSi}_{2}$ & $70 \mu \mathrm{m}$ & $2-5 \% \mathrm{wt}$. & Stir casting & {$[38]$} \\
$\mathrm{VN}$ & $2-8 \mu \mathrm{m}$ & $15 \% \mathrm{wt}$. & Hot press sintering & {$[103]$} \\
\hline
\end{tabular}

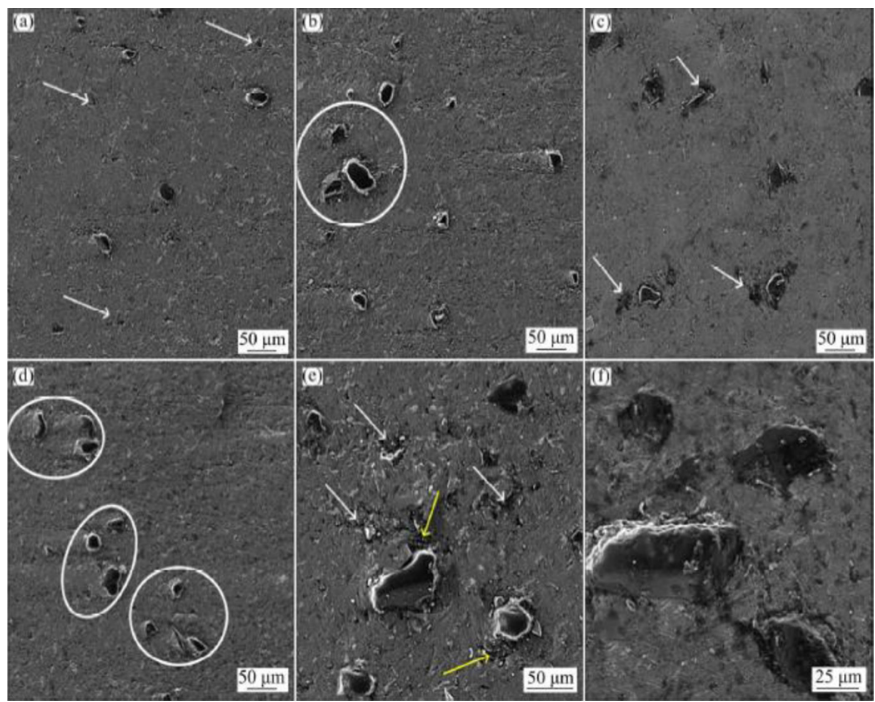

Fig. 2. SEM images of composites with $5 \%$ and $20 \% \mathrm{~B}_{4} \mathrm{C}$ under different experimental conditions: (a) $50 \mathrm{MPa}, 20 \mu \mathrm{m} \mathrm{Al} 7075 / 45 \mu \mathrm{m}$

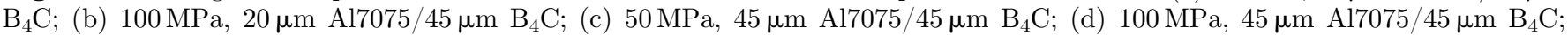

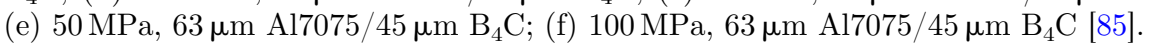

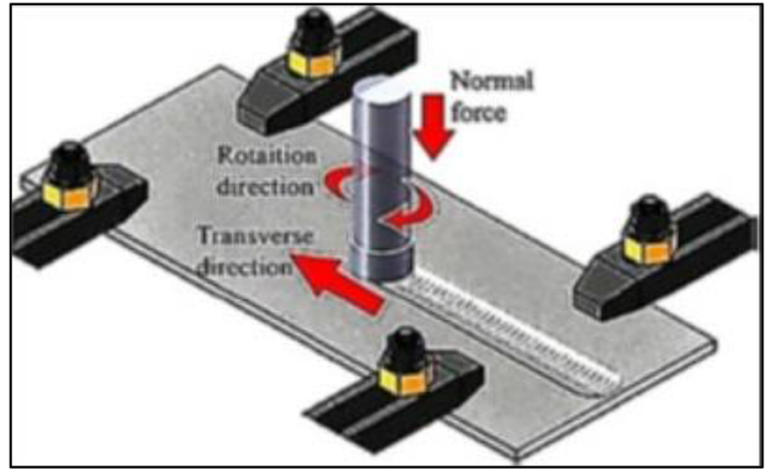

(i)

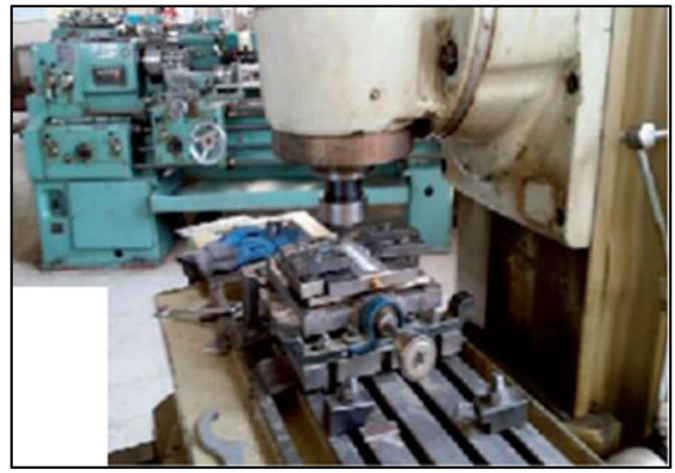

(ii)

Fig. 3. (i) Schematic of FSP [65] and (ii) Set up of FSP [23]. 


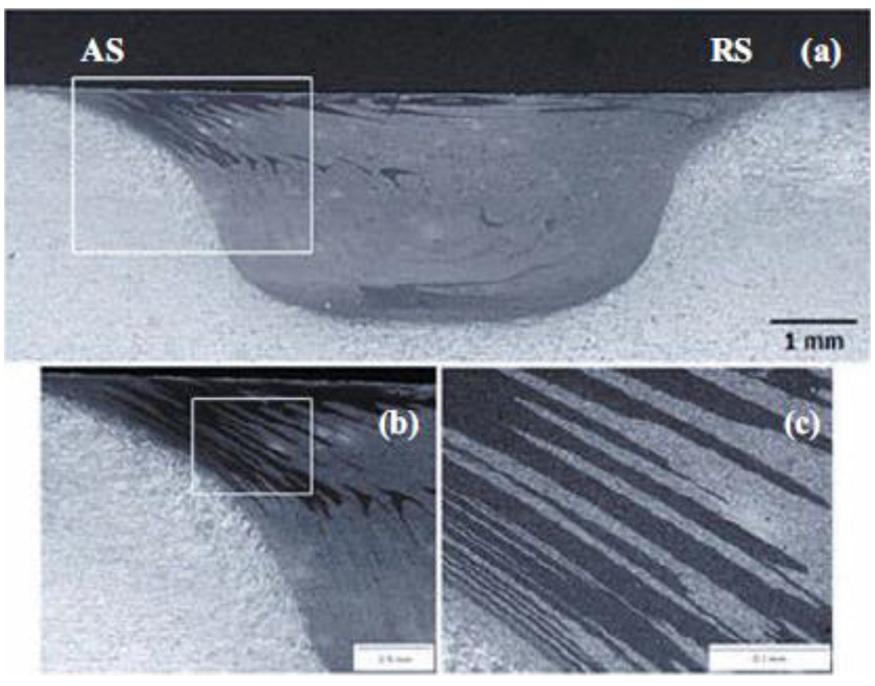

Fig. 4. (a) Cross section of S17 sample. (b) and (c) Amplified zones of the TiC particle distribution [91].

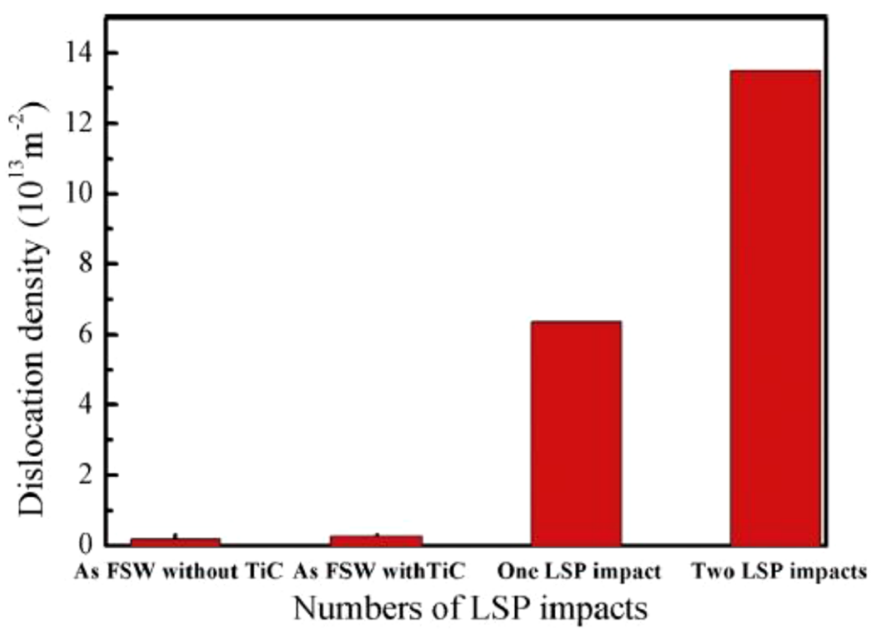

Fig. 5. Variation of dislocation density of AA7075 after different numbers of LSP impacts [93].

developing composites with homogeneous dispersion of reinforcement in the matrix. FSW is a solid-state joining method, which uses a non-consumable rotating tool with a specially designed pin and shoulder inserted into the abutting edges of sheets or plates to be joined and traversed along the line of joint. Figure 4 shows the microstructure showing the achieved homogeneous dispersion by FSP [91]. FSP causes intense plastic deformation and high strain rates in the processed material resulting in precise control of the microstructure through material mixing and densification.

Basically FSP is an outgrowth of FSW [56,57]. Laser shock peening (LSP) is a surface processing method which refines the grains and extends the life of metallic structural components and hence investigators [93] used LSP in conjunction with FSW to produce HMMCs with high-density dislocation. They developed AA7075 alloy based hybrid composites by FSW, followed by LSP on AA7075. The specimens in their study were shocked by the laser with a $1.5 \mathrm{~mm}$ spot diameter, and $8 \mathrm{~J}$ pulse energy released by a convergent lens with a focal length of $120 \mathrm{~mm}, 60 \%$ overlap rate and different numbers. Also flowing clean water and black paint were chosen to reduce the reflection of shock waves and the laser thermal injury to the laser shock peened surface with a thickness of approximately 1 and $0.1 \mathrm{~mm}$. Figure 5 shows the improvement in dislocation density due to LSP. From Figure 5, it can be inferred that LSP with 2 impacts is advantageous to increase the dislocation density in the composite. Higher the dislocation density, more nucleation sites for the secondary precipitation of strengthening phase during intentional deformation and heat treatment. 

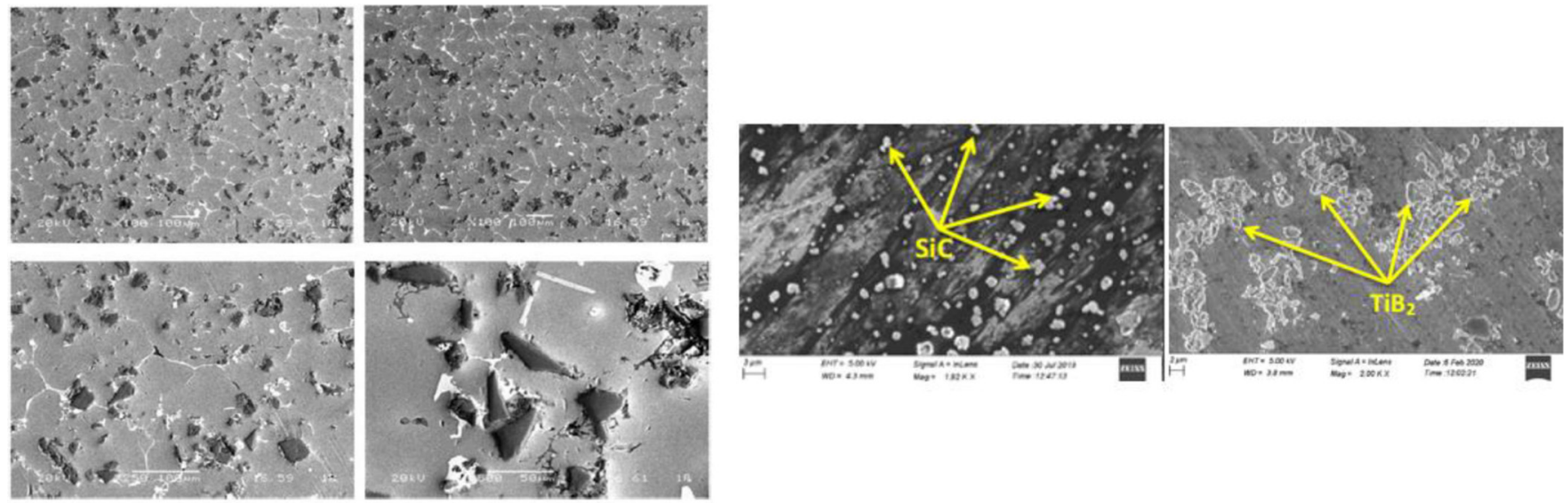

Fig. 6. (i): SEM images of the polished surface of composite reinforced with $10 \% \mathrm{SiC}$ particle [34]. (ii): Fairly uniform dispersion of SiC and TiB2 attributes throughout the aluminium matrix [74].

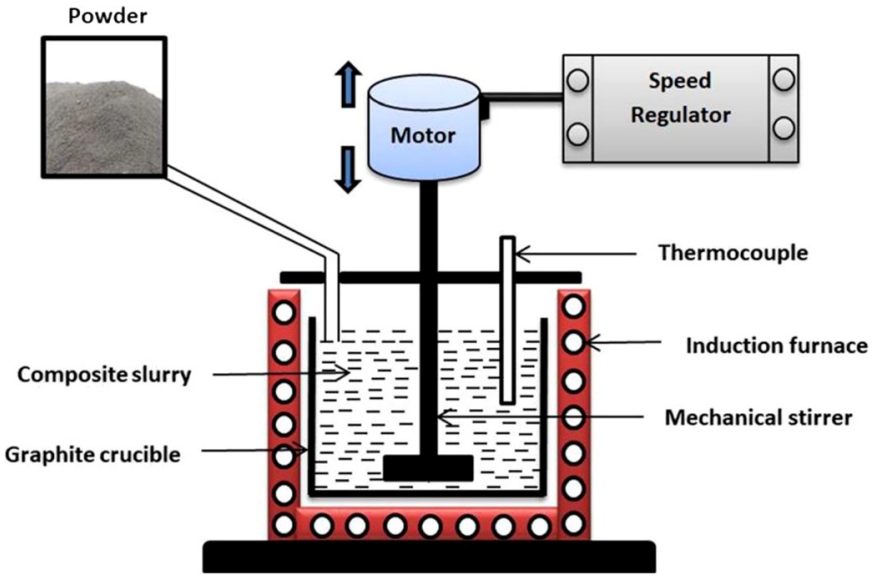

Fig. 7. Schematic diagram of stir casting setup [74].

\subsection{Liquid state processing techniques \\ 4.2.1 Stir casting}

MMCs are generally produced by different techniques like, powder metallurgy, squeeze casting, and the stir casting. Stir casting is a least expensive technique as compared to others and also it is possible to achieve homogeneous distribution of reinforcements Figure 6 $[17,34,63,74,95]$.

This process provides a minimal damage to reinforcement with no limitation on stir cast components size and shape [36]. This process involves melting of the matrix material, and pouring the reinforcements into the melt and achieving an appropriate distribution and bonding through stirring. This technique is very basic and versatile, and also, being used for big quantity manufacturing [66]. The schematic representation of stir casting is shown in Figure 7. But some of the challenges reported in respect of this technique is that improper distribution, poor wettability and porosity formation $[26,67]$ and also higher stirring time leads to formation of voids and agglomeration of reinforcements [7]. The various stir cast processing parameters used by the investigators in the past for AA7075 matrix composites have been listed in Table 3 .

\subsubsection{Squeeze casting and stir-squeeze casting}

The researchers [82] prepared AA7075 alloy based alumina reinforced MMCs by squeeze casting technique. Initially the alloy temperature was raised to $750{ }^{\circ} \mathrm{C}$ and alumina particles were charged into a preheater for pre heating at $300^{\circ} \mathrm{C}$. Once the alloy melts, it is agitated by a stirrer between the speed range $400-500 \mathrm{rpm}$. The alumina particles are then introduced in the vortex and melt is stirred continuously at $500 \mathrm{rpm}$ for $5 \mathrm{~min}$. Melt is then poured into a die which is preheated to $150{ }^{\circ} \mathrm{C}$. A squeeze pressure of $125 \mathrm{MPa}$ was applied for $15 \mathrm{~s}$ during the solidification of composite. Investigator [22] fabricated aluminium alloy $/ \mathrm{SiC}_{\mathrm{p}}$ composites by squeeze casting. The molten AA7075 at $800^{\circ} \mathrm{C}$ was squeezed into a preheated ceramic preform at $580^{\circ} \mathrm{C}$ with a pressure of $75 \mathrm{MPa}$. The casting is held under pressure for about $3 \mathrm{~min}$ and cooled down to the room temperature. The researchers in [39] used the squeeze casting set up as shown in the schematic diagram of Figure 8.

AA7075 of required quantity is melted in an induction electric resistance furnace at a temperature of $800^{\circ} \mathrm{C}$ with a shield of argon atmosphere. The reinforcement particles were initially preheated to $250^{\circ} \mathrm{C}$ for $1 \mathrm{~h}$ in a pre-heater furnace. This aids for removing the moisture content and to enhance wettability. An alumina coated stainless steel stirrer is used for the stirring. The melt is stirred at $400 \mathrm{rpm}$ for $5 \mathrm{~min}$. The reinforcements are then added to melt at a constant flow rate. The depth of immersion of stirrer was at two-third of the height of the melt for even distribution of particles in the matrix. After the completion of stirring cycle, the mixed reinforced melt is poured into a preheated die, through a preheated run-way channel. The temperature of melt is kept constant at $750{ }^{\circ} \mathrm{C}$, while pouring. On completion of the pouring, a squeeze pressure of $393 \mathrm{kN}$ is applied to the molten melt in 


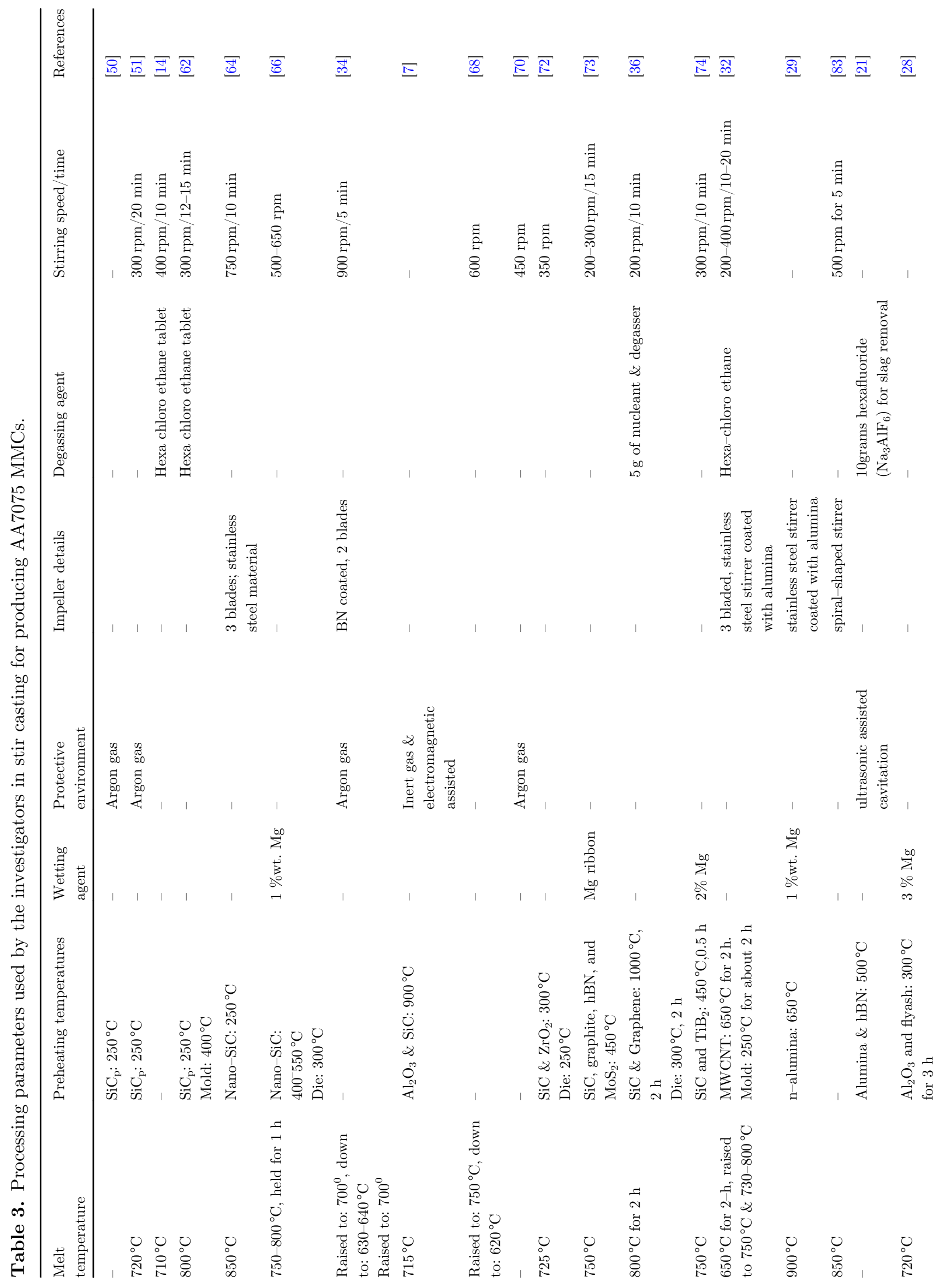




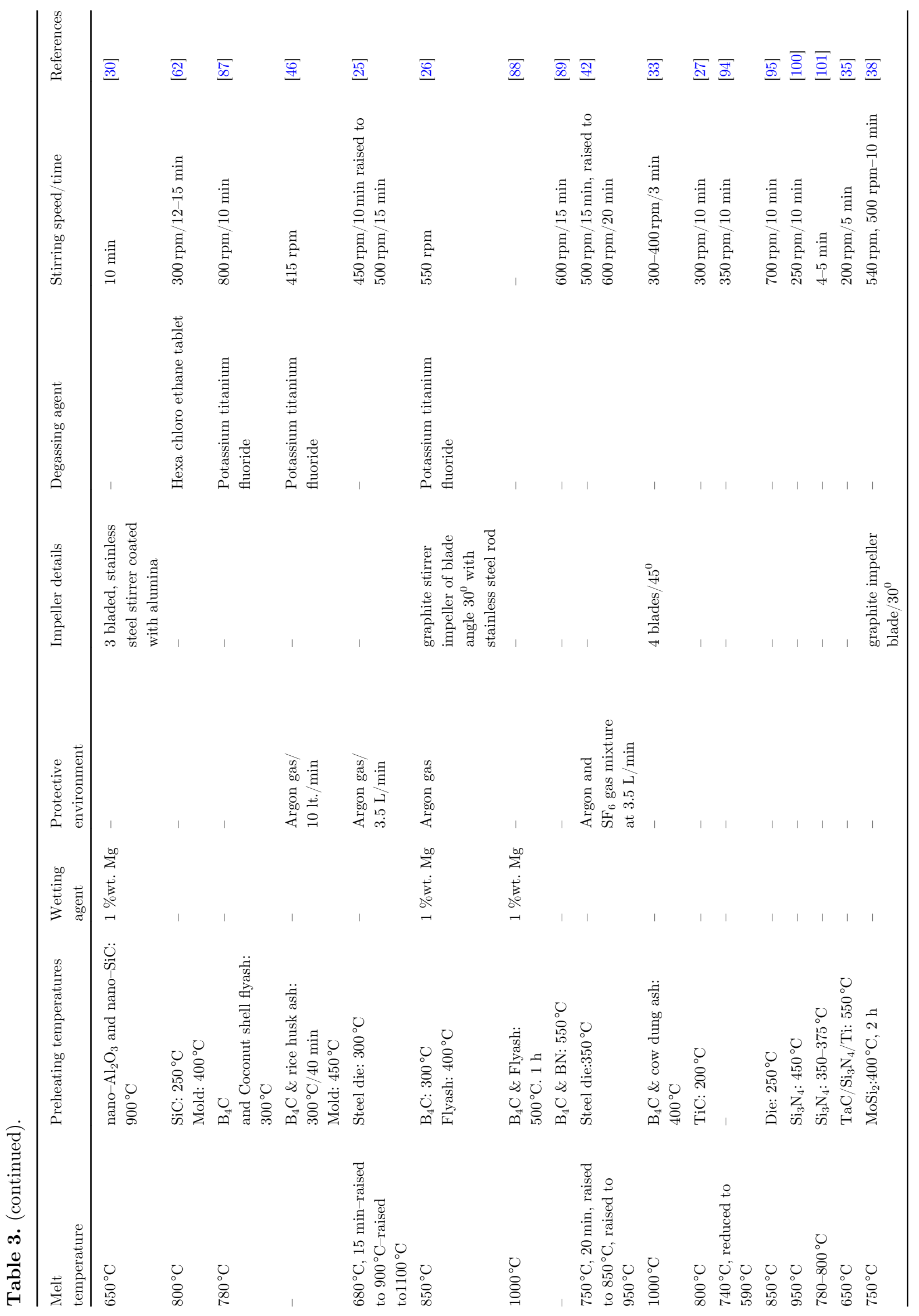




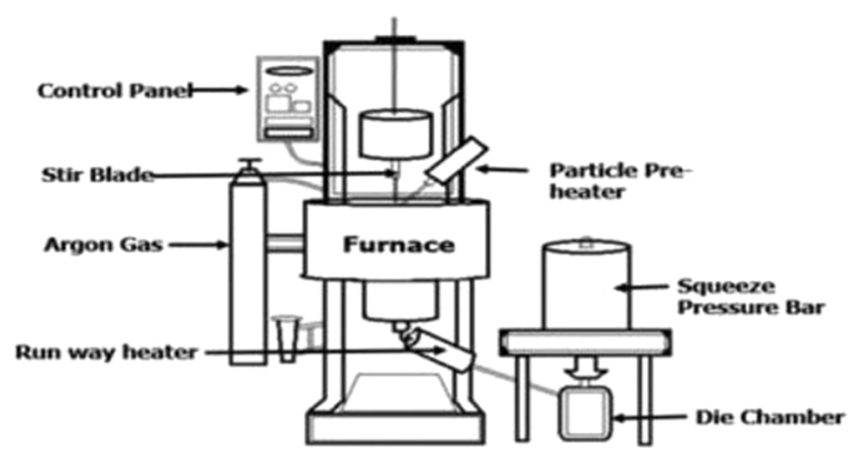

Fig. 8. Schematic depiction of stir-squeeze casting setup [39]. (a)
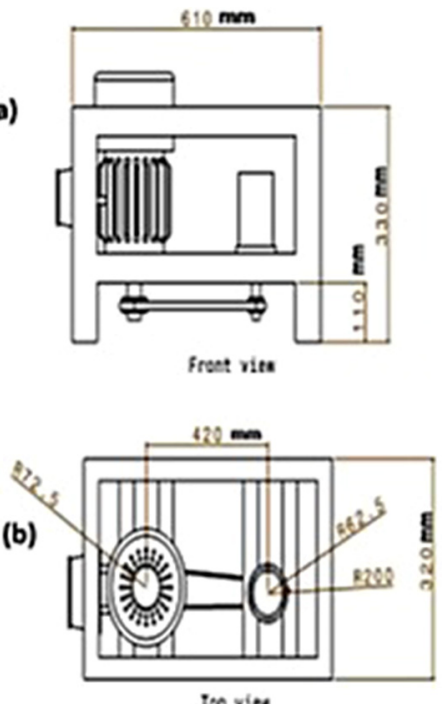

Tog vite

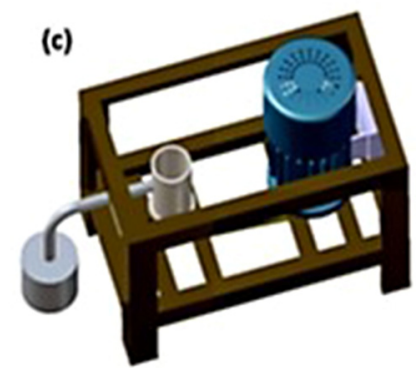

Fig. 9. Schematic depiction of centrifugal casting machine showing orthographic views ((a) \& (b)) and isometric view(c) [61].

a die chamber. Inside of the die chamber is coated with a graphite lubricant for protecting the die and for easy removal of castings.

\subsubsection{Centrifugal casting}

The schematic diagram of centrifugal casting adapted by [61] is as shown in Figure 9. It is one of the widely adapted, simplest and low cost process to achieve continuous gradient composites. The centrifugal force resulting during the mold rotation is a key parameter in order to create a continuous gradient in the composites. This force distributes the constituent (reinforcements) from the axis of rotation (core) to the periphery (surface) in the continuous manner without any mechanically weak interfaces based on their density. Besides forming the gradient structure, the centrifugal force also helps in providing complete mold filling with the required microstructure control in the product. In their study, researchers used aluminium alloy matrix material which was superheated to $780^{\circ} \mathrm{C}$ at a heating rate of $25^{\circ} \mathrm{C} / \mathrm{min}$ in a resistance furnace $(7.5 \mathrm{~kW})$ under the normal air atmosphere.
The $\mathrm{SiC}$ particles were preheated to $400{ }^{\circ} \mathrm{C}$ for $30 \mathrm{~min}$ before they are poured into molten metal to obtain the composite slurry. The slurry is agitated with a stirrer to provide the wetting between particles and the molten metal. The pouring temperature of the slurry is maintained nearly at $700{ }^{\circ} \mathrm{C}$. The preheating of graphite mold is done at $250{ }^{\circ} \mathrm{C}$ to prevent the mold chilling effect. The mold rotational speed is $700 \mathrm{rpm}$.

\subsubsection{In-situ process}

In this process, the matrix material is initially melted. Then the reinforcements are formed in situ in the molten alloy by displacement reactions between alloying elements, or between the alloying elements and the ceramic compounds. In situ process avoids the problems of particle clustering and the loss of particles when the traditional spray forming processes are used. Fine particles with the size of sub microns can be formed, which is hard to achieve by the conventional injection processes [96]. In their study it is observed that fine TiC particles decrease effectively the growth rate of the grains in the solidification process, hence 3 wt. $\%$ TiC $/ 7075$ composite showed the grain size smaller than that of the alone 7075 alloy Figure 10. This technique is also adapted by researchers [24,97-99] for their investigation.

\subsection{Other techniques}

\subsubsection{Rheoforming}

The investigators [58] in their study prepared n-SiC/7075 AMCs semisolid slurries, further they are transferred into a die cavity and rheoformed. The die is preheated to $300^{\circ} \mathrm{C}$. A lubricant consisting of a mixture of graphite and water is used to reduce the friction between die and semisolid slurries. The rheoforming experiments are carried out on a hydraulic press of $2000 \mathrm{kN}$. The semisolid slurries are rheoformed under a force of $2000 \mathrm{kN}$. Meanwhile, a rheoforming of the AA7075 matrix is also carried out under the same conditions to compare their mechanical properties to n-SiC/7075 AMCs. The schematic of rheoforming equipment used in their study is as shown in Figure 11.

Other techniques which are rarely adapted for producing AA7075 MMCs include liquid pressing process [71], spray deposition [59] and high pressure torsion [80].

The summary of various production processes adapted by researchers for producing AA7075 matrix based composites has been depicted in Figure 12 and the reinforcement specific production approaches have been tabulated in Table 2.

\section{List of research and findings related to AA7075 MMCs during the year 2010-20}

\subsection{Research on the composites based on carbides}

Harikrishna Rana and Vishvesh Badheka [4] fabricated AA7075 matrix composites by dispersing hard $\mathrm{B}_{4} \mathrm{C}$ in to it. These reinforcing particles are in the range $15-18 \mu \mathrm{m}$. The fabrication technique adapted in this study is friction stir processing. The researchers carried out parametric inves- 

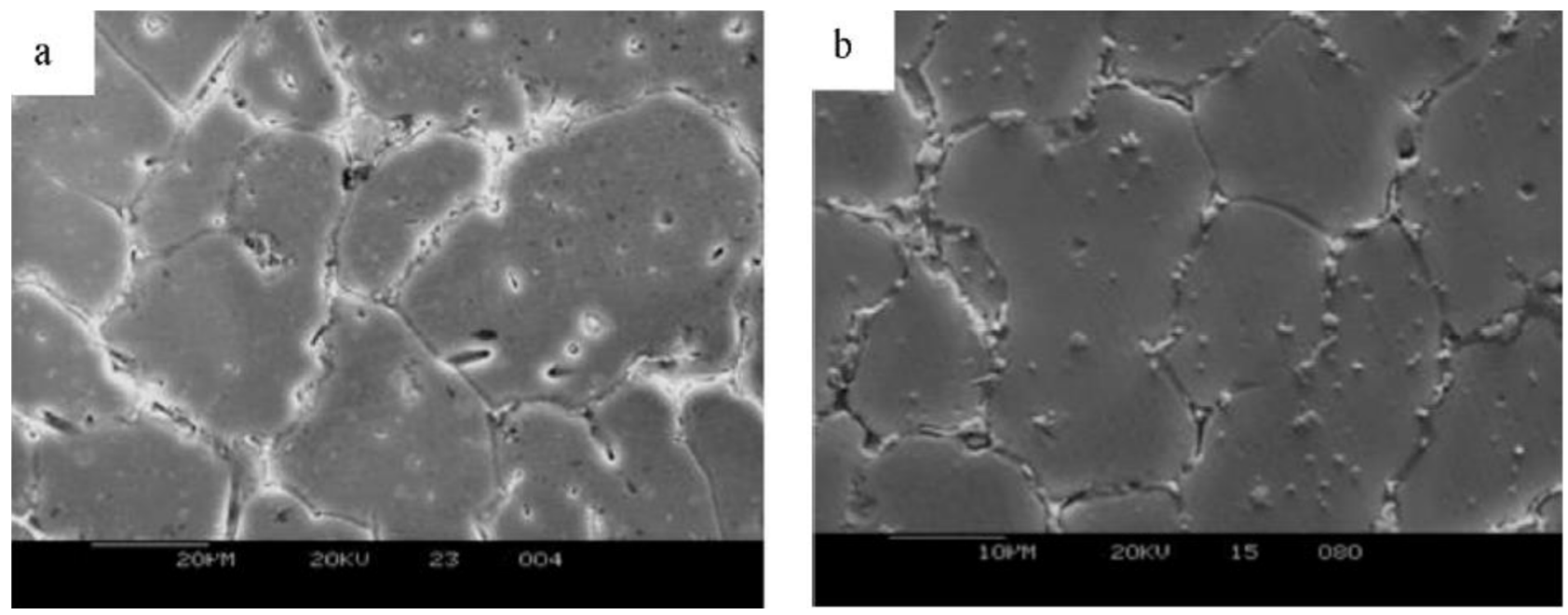

Fig. 10. Microstructure of the matrix alloy and $3 \mathrm{wt} . \% \mathrm{TiC} / 7075$ composite showing the grain size of the composite is smaller than that of the alone 7075 alloy.

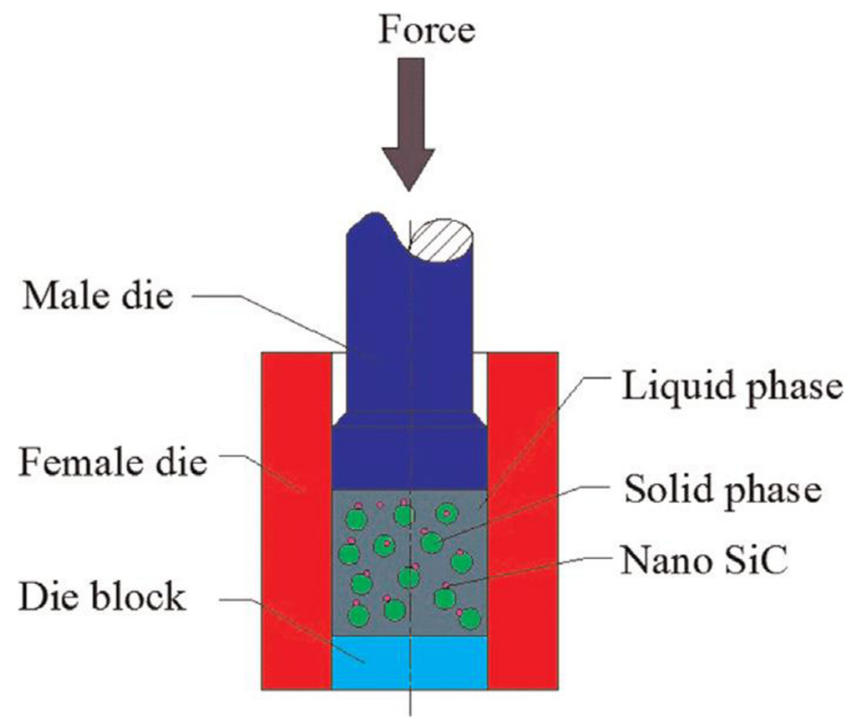

Fig. 11. Schematic diagram of the rheoforming die [58].

tigation to obtain homogeneous distribution of reinforcements in the substrate matrix by adapting different combination of parameter sets like tool rotational speed and alteration in direction of tool travel. The conclusions of the study are that lowest tool rotational speed and changing tool travel direction resulted in homogeneous distribution of $\mathrm{B}_{4} \mathrm{C}$ in the alloy and is confirmed by microstructure studies.

Chuandong $\mathrm{Wu}$ et al. [8] have produced AA7075 composite by reinforcing $7.5 \%$ wt. of $\mathrm{B}_{4} \mathrm{C}$ and synthesized by plasma activated sintering (PAS) and investigated the effect of temperature, in the range of $450-540^{\circ} \mathrm{C}$, and holding time on the densification characteristics of AA7075- $\mathrm{B}_{4} \mathrm{C}$ composites. Nearly full density combined with good spreadability, relatively high Vicker's hardness, high bending strength, high compression yield strength and fracture strength are found to be attainable at $530^{\circ} \mathrm{C}$ and a short PAS holding time of $3 \mathrm{~min}$. Also raising the sintering temperature to $540^{\circ} \mathrm{C}$ or extending the holding time is found to increase of solid-state diffusion on the surface and formation of the $\mathrm{MgO}$, resulting in the reduction of bending strength.

Qiang Shen et al. [9] prepared AA7075/ $\mathrm{B}_{4} \mathrm{C}(2.5,5$, 7.5, 10 and $12.5 \%$ wt.) composites by milling powder mixtures using a shaker-mixer mill, sintering the milled mixtures using plasma activated sintering (PAS), and heat treating the sintered product. Increasing the $\mathrm{B}_{4} \mathrm{C}$ quantity has improved the hardness, bending strength, and compressive yield strength of composite. But addition of higher weight percentage of $\mathrm{B}_{4} \mathrm{C}$ led to agglomeration, reducing the hardness and bending strength of the composite. Excellent mechanical properties are due to good interfacial bonding between the matrix alloy and reinforcement.

Rajesh Kumar Bhushan et al. [17] have fabricated AA7075, AA7075-10 \%wt. SiC (20-40 $\mu \mathrm{m})$ and AA7075-15 $\%$ wt. $\mathrm{SiC}(20-40 \mu \mathrm{m})$ composites by stir casting method and have analyzed composites using SEM, XRD, DTA and electron probe microscopic analysis (EPMA). Authors have concluded that the uniform distribution of $\mathrm{SiC}_{\mathrm{p}}$ is possible to achieve by stir casting and have found that there are no secondary chemical reactions, and is confirmed by XRD and EPMA analysis. By DTA analysis, it is concluded that the developed composites are suitable for applications where the temperature could be as high as $1250^{\circ} \mathrm{C}$.

$\mathrm{Lu}$ et al. [21] in their investigation have reinforced a mixture of $50 \%$ vol. $\mathrm{SiC}_{\mathrm{p}}$ and $5 \%$ vol. Cr particles in aluminium alloy 7075 by squeeze casting to produce HMMCs. The aim of their investigation was to understand the mechanical and thermo-physical characteristics of produced composites. 


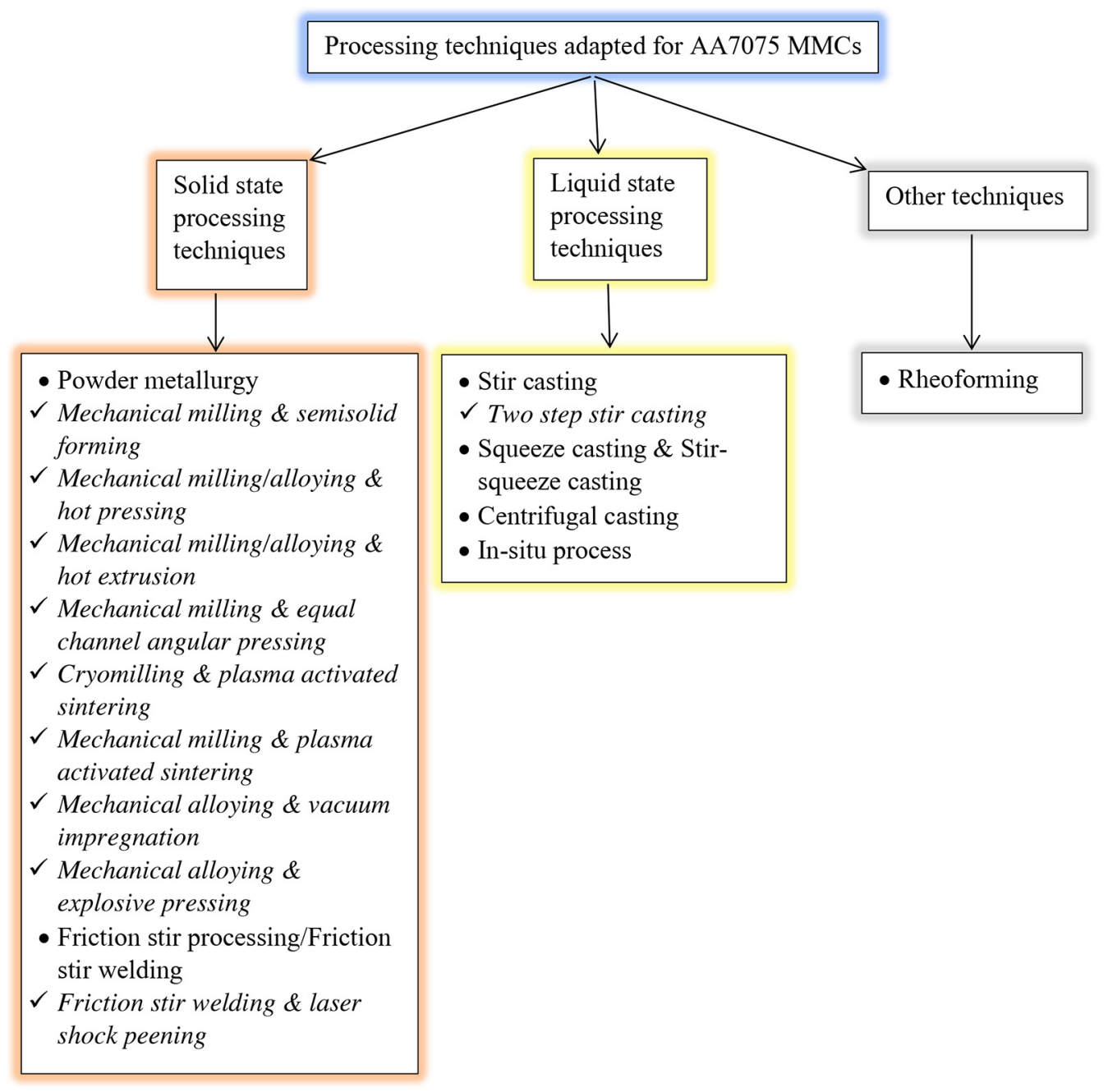

Fig. 12. Different production methods adapted to produce AA7075 matrix based composites.

Ramkumar et al. [27] have developed TiC reinforced AA7075 MMCs to understand microstructure, mechanical and tribological behavior of the composites. The quantity of reinforcement is $2.5,5$, and $7.5 \% \mathrm{wt}$. and the fabrication approach was stir casting with bottom pouring facility. The results indicated that the bending strength of composite with $7.5 \%$ wt. TiC had noticeable improvement by 5.8 times when compared to base alloy, which resulted due to the grain refinement, uniform distribution, dispersion of reinforcement particles in the matrix. Also increasing of reinforcement in the matrix had showed an enhanced resistance to wear because of increase in strength of the matrix, dispersion strengthening and very good interfacial bonding.

Devaganesh et al. [31] conducted tests to understand the mechanical and tribological properties of $\mathrm{SiC}$ reinforced AA7075 MMCs. The composites are also reinforced with $5 \%$ wt. of solid lubricants like Gr, $\mathrm{MoS}_{2}$ and h-BN along with $\mathrm{SiC}$ to produce three kinds of hybrid composites. The results indicated that $\mathrm{Al} 7075$ with $5 \%$ wt. $\mathrm{SiC}$ and $5 \%$ wt. graphite composite performed well among all other hybrid composites by evincing excellent mechanical and tribological properties which might be due to the synergic effect of graphite with the AA7075-SiC MMC.

Ficici [34] has studied the surface roughness in drilling particle-reinforced composites. In this study he reinforced silicon carbide $\left(\mathrm{SiC}_{\mathrm{p}}\right)$ in AA7075 matrix by stir casting method. The results of the drilling test indicate that the feed and cutting speed have very strong effect on the surface roughness of matrix alloy and composite materials.

Hemalatha et al. [36] have fabricated SiC and Graphene reinforced AA7075 based hybrid metal matrix composites. Their objective was to understand the effect of reinforcements of the matrix alloy. The fabrication approach adapted in this study was stir casting. Here the chosen mass of $\mathrm{SiC}$ was 10 and $15 \%$ wt. and Graphene maintained constant at $1 \%$ for both compositions. The conclusion of this research is that the addition of reinforcement from 10 to $15 \%$ wt. the mechanical properties increased whereas the wear rate decreased.

Karthikeyan et.al [50] in 2010 have produced 7075 Al-SiC composites by stir casting method with changing amount of $\mathrm{SiC}$ particles (10, 15 and $20 \%$ vol.) and 


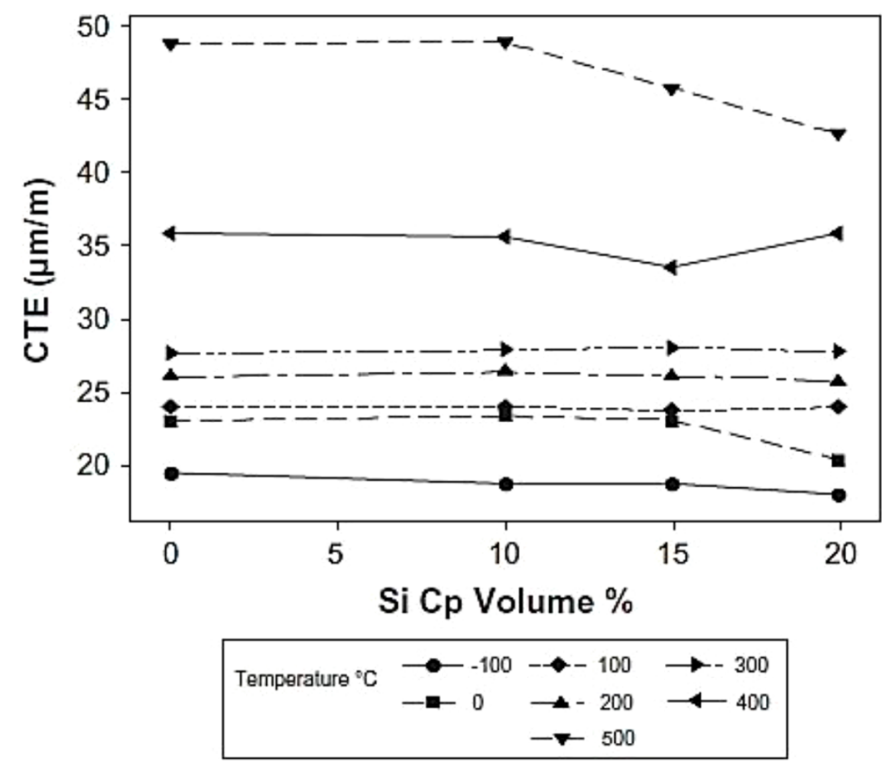

Fig. 13. Variation of CTE for different temperatures [51].

conducted the calorimetric study by differential scanning calorimetry (DSC) to analyze specific heat properties of alloy and composites. It is observed in the study of all types of composites with the same conditions had entirely different heat capacity $\left(C_{p}\right)$ values and were lower than the AA7075.

Keeping in mind the demand for lightweight, dimensionally stable materials for critical aerospace applications Karthikeyan et al. [51] have investigated the thermo physical property of stir cast AA7075 reinforced with $\mathrm{SiC}$ composites (10, 15 and $20 \%$ vol.) in thermo mechanical analyzer (TMA). Their experimental work indicated that composites had lower coefficient of expansion (CTE) values than that of alloy. Figure 13 shows that higher the volume fraction, the smaller is the CTE value of the metal matrix composites.

In the research work of Ahmed et al. [52], PM technique is used to produce the $\mathrm{n}-\mathrm{SiC}_{\mathrm{p}} / 7075$ AMMCs. The composites were reinforced with 1 and $5 \%$ vol. fraction of $\mathrm{n}-\mathrm{SiC}_{\mathrm{p}}$. The alloy and composites are mechanically tested for knowing the modulus of elasticity, yield strength, ultimate tensile strength and ductility. The conclusions of these authors is that by reinforcing $n-\mathrm{SiC}_{\mathrm{p}}$, a significant variation is observed in microstructure and tensile properties of the AA7075 and no grain refinement is noticed in the composites. The grain structure of composites is noticed to be coarser than that of the base alloy. The hardness and tensile strength of the composites are observed to be fairly low (25-35\% and 35-44\% decrease in the hardness and ultimate tensile strength of the composites, respectively) as compared to base alloy. Deterioration in properties is due to segregated magnesium at the oxidized $\mathrm{n}-\mathrm{SiC}_{\mathrm{p}}-\mathrm{Al}$ interfaces and grain boundaries, resulting in reduced precipitation hardening of the aluminium matrix.
Rajesh Kumar Bhushan et al. [53] have analyzed the effect of cutting speed, depth of cut, and feed on surface roughness while machining of AA7075 and $10 \%$ wt. $\mathrm{SiC}_{\mathrm{p}}$ MMCs. The AA7075 and $10 \%$ wt. $\mathrm{SiC}_{\mathrm{p}}$ (particle size 20-40 $\mu \mathrm{m}$ ) composites are produced by stir casting route. The observation made by the investigators through their experiments is that the surface roughness of aluminium alloy is less in comparison to AMCs during turning by carbide as well as polycrystalline diamond (PCD) inserts. Wear of carbide and PCD inserts is found to be less while turning of aluminium alloy as compared to composites and wear of PCD insert is less as compared to wear of carbide insert while turning of composites. For optimum surface roughness while turning composite specimen by carbide insert it is suggested to maintain cutting speed within the range of $180-220 \mathrm{~m} / \mathrm{min}$, feed within range of $0.1-0.3 \mathrm{~mm} / \mathrm{rev}$, and depth of cut within range of $0.5-1.5 \mathrm{~mm}$. Also while using PCD inserts the cutting speed above $220 \mathrm{~m} / \mathrm{min}$ but at a feed of less than $0.2 \mathrm{~mm} / \mathrm{rev}$ and depth of cut less than $1.0 \mathrm{~mm}$ to be maintained.

In the year 2010, Saeed Zare Chavoshi [54] has investigated the effects of feed, depth of cut and cutting speed on flank wear of tungsten carbide and polycrystalline diamond (PCD) inserts in CNC turning of AA7075 and $10 \%$ wt. of $\mathrm{SiC}$ composite. Also artificial neural network (ANN) and co-active neuro fuzzy inference system (CANFIS) are used to predict the flank wear of tungsten carbide and PCD inserts. Conclusions made by this researcher is that increase in feed, depth of cut and cutting speed increases the flank wear. The feed and depth of cut are found to be the most effective parameters on the flank wear but the cutting speed has least effect and there is no interaction between the feed, depth of cut and cutting speed. Also the predictive ANN model is observed to be much more accurate in predicting of tool flank wear as compared to CANFIS model.

The influence of pin geometry on the macrostructure, microstructure and mechanical properties of the friction stir welds, reinforced with n-SiC particles are studied by Bahrami et al. [56] during 2014. Study is undertaken with five FSW tools with different pin geometries i.e. threaded tapered, triangular, square, four-flute square, and fourflute cylindrical (TT, T, S, FFS, and FFC). Of all these, highest ultimate tensile strength is obtained with triangular pin tool. Lowest average microhardness value as well as the more homogeneous particle dispersion is found to be in threaded tapered specimen. Also four-flute cylindrical specimen resulted the highest average microhardness with respect to other specimens.

Bahrami et al. [57] fabricated AA7075 matrix based $\mathrm{n}$-SiC reinforced composites by friction stir welding (FSW) and conducted analysis on the influence of $\mathrm{SiC}$ on fatigue life, impact energy and tensile strength of alloy and composites. These researchers adapted threaded tapered friction stir welding tool for FSW. In each friction stir welded joint, three distinct areas are discovered, namely stir zone (SZ), thermo-mechanically affected zone (TMAZ) and heat affected zone (HAZ). The presence of n-SiC particles, tensile strength, percent elongation, fatigue life, 
and toughness of the joint improved significantly. The improvement of mechanical properties is due to finer grain size of SZ associated with n-SiC particles.

Jiang and Wang [58] prepared semisolid slurry of AA7075 MMCs by reinforcing $\mathrm{n}$-SiC particulates which is further rheoformed to get cylindrical components. Yield strength and ultimate tensile strength of these components made of composite are superior in comparison to that of base alloy.

$\mathrm{Wu}$ et al. [59] investigated the flow stress behavior and processing map of extruded aluminium composites with $\mathrm{SiC}$ as reinforcements. They adapted spray deposition technique and the results showed that true stress-true strain curve exhibited almost a rapid flow softening behaviour without an obvious work hardening, and the stress decreased with increase in temperature and decreasing strain rate.

Shrivastava et al. [60] have fabricated $\mathrm{SiC}$ based AA7075 MMCs by stir casting route. The $\mathrm{SiC}$ were in the range $45-50 \mu \mathrm{m}$ and their reinforced quantity was $10 \% \mathrm{wt}$. The objective of these researchers is to assess sliding wear under dry, oil lubricated and inert gas environments. The test results showed that wear rate is minimal for both the alloy and the composite under lubricated condition in comparison to dry and inert condition. Rate of wear has increased with the normal load and sliding speed and it reached peak in inert condition of matrix alloy at $30 \mathrm{~N}$. Also the coefficient of friction is observed to have reduced for MMCs as compared to alloy under all the conditions of lubrication.

Prabhu [61] fabricated AA7075-SiC composites and conducted experiments to arrive at the material characterization. The centrifugal casting is adapted to reinforce 6 and $9 \%$ wt. of $\mathrm{SiC}$ in the alloy matrix. His research output shows that as the quantity of $\mathrm{SiC}$ is increased accordingly the properties like hardness, strength and wear resistance have found to improve. The composite with $9 \%$ wt. reinforcement is found to be having superior properties as compared to alloy and the other composite under consideration.

Bandhu et al. [62] fabricated four types of AA7075 based composites. These composites are reinforced with $\mathrm{SiC}, \mathrm{Al}_{2} \mathrm{O}_{3}, \mathrm{~B}_{4} \mathrm{C}$ and $\mathrm{TiB}_{2}$ respectively each with $15 \%$ wt. The researchers have used stir casting for the production of composite. The composites produced are tested for tensile strength, hardness, and impact strength and these are noticed to be higher in comparison to the alloy.

Lee et al. [105] developed AA7075 MMCs by reinforcing $\mathrm{SiC}$ particles of size $10,30 \mu \mathrm{m}$, and bimodal $(10+30) \mu \mathrm{m}$ in quantity of $49.5,54.1$ and $56.5 \%$ vol. respectively. The investigators worked on to understand effects of $\mathrm{SiC}$ particulate size on dynamic compressive properties of the composites. It is observed that after the quasi-static compressive tests, cracks are formed in a shear mode as a number of $\mathrm{SiC}$ particles readily initiated cracks, which resulted in relatively low compressive strains which is far below that of the AA7075 matrix.

Suresh et al. [63,64] have used n-SiC (50 nm) to reinforce them in AA7075 matrix. They synthesized composites by stir casting method and also their wear and friction characteristics are evaluated. $\mathrm{SiC}$ is reinforced in varying proportion of 1,2,3 and $4 \%$ wt. in AA7075 matrix for obtaining MMCs. It is concluded that by increasing applied load and sliding distance the wear performance of the test samples linearly decreases. There is a relative reduction in weight loss and friction coefficient with increase of quantity of nano reinforcements. The most efficient result is observed to have achieved at $4 \%$ wt. of n-SiC.

Ramezani et al. [65] used friction stir processing and have developed the composites consisting of nano-SiC particles reinforced in AA7075 alloy. The mean size of $\mathrm{SiC}$ are in the range $45-65 \mathrm{~nm}$. These researchers have studied the influence of input parameters along with speed of rotation, speed of traverse and number of pass on the tool wear, microhardness and the topography through the response surface methodology. Analysis of variance showed that quadratic polynomial models are fitting to predict tool wear and microhardness. Also the results showed that tool wear also varied between 12 and $116 \mathrm{~mm}$ under different parameters and the speed of rotation, number of passes of 52.9 and $13.1 \%$, respectively, making higher influence on tool wear.

Suresh and Sudhakara [66] carried out the electric discharge machining and mechanical characteristics of AA7075/n-SiC composites that are fabricated by stir casting techniques. These have incorporated n-SiC with 2, 4 and $6 \%$ wt. quantity along with $\mathrm{Mg} 1.5 \%$ wt. The results of this study showed that AA7075-6\%wt. SiC nanocomposite material having highest hardness in comparison to base alloy and other category of nano composites. The gap voltage $(\mathrm{V})$ is the prime influential parameter for material removal rate followed by wire feed and pulse-off time. Also it is noticed that quantity of reinforcements is the prime influencing parameter for surface roughness.

Singh et al. [67] reinforced $\mathrm{SiC}(60-70 \mu \mathrm{m}, 8 \% \mathrm{wt}$.$) in$ AA7075 matrix by using stir casting techniques. These researchers conducted dry sliding wear of composites in pin-on-disc machine. Their experimentation indicated that the coefficient of friction and wear rate are decreased to an amount equal to $30-40 \%$ in comparison to the base alloy

Chul Jo et al. [71] have reinforced $\mathrm{SiC}$ and $\mathrm{B}_{4} \mathrm{C}$ particles in AA7075 matrix by liquid pressing process. The volume fraction ratio maintained was 1:1. The HMMCs developed in this study indicated high dynamic compressive strength and a good strain rate.

Javdani and Daei-sorkhabi [85] have cold compacted AA7075- $\mathrm{B}_{4} \mathrm{C}$ blends and pressed at semisolid state to prepare MMCs. The researchers aimed at understanding the effect size of the matrix $(20,45$ and $63 \mu \mathrm{m})$, reinforcement quantity $(5,10$ and $20 \%$ vol.) and semisolid compaction pressure (50 and $100 \mathrm{MPa})$ on the morphology, microstructure, density, hardness, compression and bending strength. The results revealed that composites with $20 \mu \mathrm{m} \mathrm{AA7075}$ and $20 \%$ vol., $45 \mu \mathrm{m} \mathrm{B} \mathrm{C}_{4} \mathrm{C}$ powder pressed under $100 \mathrm{MPa}$ possessed the highest values of hardness (HV 190) and compressive strength (336 MPa).

$\mathrm{Wu}$ et al. [86] produced $\mathrm{AA} 7075 / \mathrm{B}_{4} \mathrm{C}$ composites by cryomilling and consolidation under a uniaxial pressure of $20 \mathrm{MPa}$. The focus of investigation is to understand the influence of content of $\mathrm{B}_{4} \mathrm{C}$ on microstructure and mechanical behavior of composites. The result of this study has revealed that the heat treatment does not have any influence in the annealing of the dislocations in the composites. A high dislocations density is noticed inside the 
grains of alloy lying at the vicinity of the $\mathrm{B}_{4} \mathrm{C}$ particles. Also the heat treated specimen, having high yield strength, displayed a plasticity of $11.7 \%$.

AA7075-TiC $(3.5 \mu \mathrm{m})$ composites produced by FSP have been studied for corrosion behavior [91] in the year 2018. Polarization tests have been conducted by Electrochemical Work Station. The molarity of the electrolyte is changed to 1,2 , and $3 \mathrm{M} \mathrm{NaCl}$. Corrosion rates are calculated in terms of the corrosion current by using Tafel curves. These investigators concluded the rate of corrosion of all the samples had raised with the increase the concentration of the $\mathrm{NaCl}$ irrespective of the quantity of TiC.

Wang et al. [93] have studied the influence of laser shock peening on the coefficient of thermal expansion (CTE) of AA7075 matrix composites. Size of TiC taken is approximately $6-8 \mu \mathrm{m}$. The composites are fabricated by friction stir processing. The results of this study showed that the CTE value of the laser shock peened samples having $\mathrm{TiC}$ has reduced by $30 \%$ in comparison with that of the asfriction stir weld sample.

Liu et al. [106] developed MMCs based on AA7075 with $\mathrm{B}_{4} \mathrm{C}$ reinforced in it. The adapted cryomilling and one-step consolidation process. These researchers studied the microstructure and mechanical behavior of produced composites. In this research analysis of the strengthening mechanism showed that increasing of sintering temperature leads to the reduction of grain-boundary strengthening and dislocation strengthening in the composites.

\subsubsection{Summary of the properties of AA7075 composites based on carbides}

The properties noticed by experimentation on composites based on carbides has been listed in Table 4 .

\subsection{Research on the composites based on oxides}

Bera et al. [12] in the work during 2013 fabricated the AA7075 based composite by dispersing nano- $\mathrm{TiO}_{2}(10$ and $20 \%$ wt.) by mechanical milling and consolidation by equal channel angular pressing (ECAP). The compacts obtained by ECAP exhibited higher density (90\% of theoretical density), superior hardness $(3.72 \mathrm{GPa} / 344 \mathrm{VHN})$ and higher stiffness (modulus of elasticity $92 \mathrm{GPa}$ ) and high compressive strength (nearly $1.7 \mathrm{GPa}$ ).

Bai et al. [18] have used mechanical milling with subsequent hot pressing to produce aluminium alloy 7075/ nano $\mathrm{Al}_{2} \mathrm{O}_{3}$ MMCs. Objective of these researchers is to assess the mechanical and high temperature tribological characteristics of composites. The composites with $5 \% \mathrm{wt}$. reinforcement is found to exhibit highest hardness, had excellent compressive property and showed a noticeable improvement in high-temperature wear resistance as compared to alloy and the lower quantity reinforced composite.

Sabbaghianrad and Langdon [80] used high pressure torsion to process AA7075/10 \%vol. $\mathrm{Al}_{2} \mathrm{O}_{3}$ to induce superplasticity in composite while tensile testing. The experimental results indicate that the grain refinement took place and Vicker's hardness has also increased with maximum elongation while tested in tension.

Zhang et al. [81] carried out the research study to know the effect of $\mathrm{T} 6$ heat treatment on microstructure and hardness of nano composites. They dispersed $1.5 \%$ wt. of nano- $\mathrm{Al}_{2} \mathrm{O}_{3}$ in AA7075 matrix by casting process. They observed that solution treatment at $480^{\circ} \mathrm{C}$ for $5 \mathrm{~h}$ and aging treatment at $120^{\circ} \mathrm{C}$ for $24 \mathrm{~h}$ is the optimum $\mathrm{T} 6$ heat treatment as the hardness of composite is superior as compared to alloy because of the microstructural refinements.

The investigators Muraliraja et al. [82] have used squeeze casting technique for producing AA7075 matrix based MMCs by dispersing $2.5 \%$ wt. of alumina $(30-50 \mu \mathrm{m})$. The observations in this research is that hardness of the composite improved by $24.5 \%$ and compressive strength by $39 \%$ as compared to the AA7075.

Hernández-Martinez et al. [90] have produced AA7075$\mathrm{ZrO}_{2}$ MMCs by planetary, horizontal attritor and shaker ball mills to assess the effectiveness in dispersing $\mathrm{n}-\mathrm{ZrO}_{2}$ particles (2 and 5 wt.\%) in matrix. The investigation showed that in the case of the planetary ball mill, a full dispersion of the $\mathrm{ZrO}_{2}$ through the matrix can be attained because an excess of the process control agent, enhances the fracture of particles instead of welding, leading to the breakdown of $\mathrm{ZrO}_{2}$ agglomerates and resulting a complete dispersion of the reinforcement.

\subsubsection{Summary of the properties of AA7075 composites based on oxides}

The properties of composites based on oxides has been listed in Table 5 .

\subsection{Research based on hybrid composites}

Lal et al. [7] produced AA7075- $\mathrm{SiC} / \mathrm{Al}_{2} \mathrm{O}_{3}$ HMMCs by inert gas-assisted electromagnetic stir-casting method. Composite having $15 \%$ wt. $\mathrm{Al}_{2} \mathrm{O}_{3}$ and $\mathrm{SiC}$ particulates (7.5\%wt.) in AA7075 are reported to be produced successfully and have studied the influence of wire cut electrical discharge machining process parameters like duration of discharge, pulse interval time, discharge current and the wire drum speed on the kerf width while machining. Taguchi method is applied for optimizing parameters and the level of importance is determined using analysis of variance (ANOVA). The experimentation showed that duration of discharge, discharge current and wire drum speed are the significant parameters.

Kannan and Ramanujam [21] have evaluated the effectiveness of two methods of processing and treatments on the mechanical characteristics of AA7075 based HMMCs. In this investigation, $1 \%$ wt. $\mathrm{Al}_{2} \mathrm{O}_{3}$ particles (avg. size: $30-50 \mathrm{~nm}$ ) and $0.5 \%$ wt. of h-BN particles (avg. size: $80-100 \mathrm{~nm}$ ) were reinforced in AA7075 matrix by ultrasonic assisted cavitation and a combinational approach of molten salt processing with ultrasonic assistance and optimized mechanical stirring. The researchers have 
Table 4. Properties of composites based on carbides.

\begin{tabular}{|c|c|c|c|}
\hline Reinforcement & Production approach & Properties achieved & References \\
\hline $\mathrm{B}_{4} \mathrm{C}$ & $\begin{array}{l}\text { Plasma activated } \\
\text { sintering }\end{array}$ & $\begin{array}{l}\text { At } 7.5 \mathrm{wt} . \% \mathrm{~B}_{4} \mathrm{C} \text {, the Vickers hardness, bending } \\
\text { strength, and compressive strength of the } \\
\text { consolidated samples were } 184.3 \mathrm{HV}, 813 \mathrm{MPa} \text {, } \\
\text { and } 895 \mathrm{MPa} \text {, respectively }\end{array}$ & {$[9]$} \\
\hline $\mathrm{SiC}, \mathrm{Cr}$ & Squeeze casting & $\begin{array}{l}\text { The addition of } \mathrm{Cr} \text { particles remarkably } \\
\text { improved the mechanical properties and thermo- } \\
\text { physical properties of the } 50 \% \mathrm{SiC}+5 \% \mathrm{Cr} \\
\text { composite in comparison to the } 50 \% \mathrm{SiC} \text { and } 55 \% \\
\mathrm{SiC} \text { composites. } \\
\text { For } 50 \% \mathrm{SiC}+5 \% \mathrm{Cr} \text { thermal conductivity is } \\
145 \mathrm{~W} \mathrm{~m}{ }^{-1} \mathrm{k}^{-1} \text {, thermal expansion is } 10.8 \times 10^{-6} \\
{ }^{\circ} \mathrm{C}^{-1} \text {, bending strength is } 821 \mathrm{MPa}\end{array}$ & {$[21]$} \\
\hline $\mathrm{SiC}, \mathrm{MOS}_{2}, \mathrm{Gr}, \mathrm{hBN}$ & Stir casting & $\begin{array}{l}\text { Composite having } 5 \% \mathrm{SiC}, 5 \% \mathrm{Gr} \text { had VHN } 176 \text {, } \\
\text { UTS } 247.21 \mathrm{MPa} \text {, compression strength } \\
61.74 \mathrm{MPa} \text { with very good wear resistance }\end{array}$ & {$[31]$} \\
\hline $\mathrm{SiC}$ & Stir casting & $\begin{array}{l}\text { Under } 0.10 \mathrm{~mm} / \mathrm{rev} \text { and } 20 \mathrm{~m} / \mathrm{min} \text { drilling } \\
\text { conditions and using high speed steel drill, surface } \\
\text { roughness values for matrix, } 5 \% \mathrm{SiC}, 10 \% \mathrm{SiC} \text {, } \\
\text { and } 15 \% \mathrm{SiC} \text {-reinforced composites were obtained } \\
\text { as } 2.57,2.59,2.61 \text {, and } 2.64 \mathrm{~mm} \text { respectively. } \\
\text { An increase in the quantity of } \mathrm{SiC}_{\mathrm{p}} \text { results in a } \\
\text { very crucial deterioration quality of the drilled } \\
\text { hole }\end{array}$ & {$[34]$} \\
\hline $\mathrm{SiC}$ & Stir casting & $\begin{array}{l}\text { Co-efficient of thermal expansion of AA7075/ } \\
\mathrm{SiC}_{\mathrm{p}} \text { composites characterized under identical } \\
\text { conditions varies significantly and composites } \\
\text { exhibit lower co-efficient of thermal expansion } \\
\text { values than the alloy. } \\
\text { Reinforcing } \mathrm{SiC} \text { produces MMC with low co- } \\
\text { efficient of thermal expansion }\end{array}$ & {$[51]$} \\
\hline n-SiC & PM & $\begin{array}{l}25 \text { to } 35 \% \text { and } 35 \text { to } 44 \% \text { drop in the hardness } \\
\text { and ultimate tensile strength of the composites is } \\
\text { observed as compared to alloy }\end{array}$ & {$[52]$} \\
\hline n-SiC & Friction stir welding & $\begin{array}{l}\text { The joints produced with rotational speed of } \\
1250 \mathrm{rpm} \text { and traveling speeds of } 40 \text { and } 50 \mathrm{~mm} / \\
\text { min, had the highest mechanical properties. } \\
\text { Owing to the presence of n-SiC } \text {, at } 1250 \mathrm{rpm} \\
\text { and } 40 \mathrm{~mm} / \text { min, ultimate tensile strength (UTS) } \\
\text { and percentage of elongation were improved by } \\
31 \% \text { and } 76.1 \% \text { respectively }\end{array}$ & {$[57]$} \\
\hline
\end{tabular}


Table 4. (continued).

\begin{tabular}{llll}
\hline Reinforcement & Production approach & Properties achieved & References \\
\hline $\mathrm{n}$-SiC & Ultra sonic assisted & Yield, ultimate tensile strength and elongation & {$[58]$}
\end{tabular}

$\mathrm{SiC} \quad$ Spray deposition

Ultra sonic assisted Yield, ultimate tensile strength and elongation

[58] $\mathrm{n}-\mathrm{SiC} / 7075 \mathrm{Al}$ composite without $\mathrm{T} 6$ are $264 \mathrm{MPa}, 357 \mathrm{MPa}$ and elongation of $7.5 \%$ respectively.

n-SiC/AA7075 composite exhibited yield strength of $381 \mathrm{MPa}$, ultimate tensile strength of $478 \mathrm{MPa}$ and elongation of $8.5 \%$

Superplastic deformation characteristics of spray deposited $7075 \mathrm{Al} / 15 \% \mathrm{SiC}_{\mathrm{p}}$ composites are found at temperature of $450^{\circ} \mathrm{C}$ and strain rate range of $0.001-0.1 \mathrm{~s}^{-1}$ with strain rate sensitivity of 0.72 . The optimum parameters of hot working for the composites are obtained to be temperature of $430-450^{\circ} \mathrm{C}$ and strain rate of $0.001-0.05 \mathrm{~s}^{-1}$

$\mathrm{SiC} \quad$ Centrifugal casting

At low sliding speed $(2 \mathrm{~m} / \mathrm{s})$ and load $(15 \mathrm{~N})$ conditions, the abrasive wear and matrix cracking are found to be dominant in comparison to the multi-mode wear mechanisms such as tribo oxidation, abrasive wear, third body wear and delamination wear are operative at higher load and speed conditions.

$\mathrm{SiC}, \mathrm{B}_{4} \mathrm{C}, \mathrm{Al}_{2} \mathrm{O}_{3}, \mathrm{TiB}_{2} \quad$ Stir casting Al7075-15\% $\quad \mathrm{B}_{4} \mathrm{C}$ composite materials exhibit greater hardness property of $164 \mathrm{BHN}$ as compared to the other reinforced composites. The tensile test shows that the Al7075-15\% $\mathrm{B}_{4} \mathrm{C}$ has excellent ultimate tensile strength of $261 \mathrm{MPa}$ when compared to other ceramic reinforced MMCs.

Highest impact strength of $11 \mathrm{~N}-\mathrm{m}$ has been seen in the composite reinforced with $\mathrm{B}_{4} \mathrm{C}$.

Age hardening of composite specimens has improved the tensile strength of the aluminium metal matrix composites from $261 \mathrm{MPa}$ to 271 $\mathrm{MPa}$

$\mathrm{SiC} \quad$ FSP

The rotation speed and pass number of $52.9 \%$ and $13.1 \%$, respectively, have the greatest impact on tool wear.

Traverse speed with more than $55 \%$ had the most effect on micro hardness comparatively.

The micro hardness reached the highest level of 127.24 Vickers

n-SiC Stir casting

it is noticed that by increasing wt.\% of $\mathrm{SiC}$ leads to increased $\mathrm{R}_{\mathrm{a}}$ and decreased MRR

$\mathrm{SiC} \quad$ Stir casting

reduction of $30 \%-40 \%$ are observed in values of coefficient of friction and wear rates for composite in comparison to alloy.

With increase in sliding speeds, the values of coefficient of friction and wear rates for both $\mathrm{Al}$ alloy and composites also increase

$\mathrm{SiC}, \mathrm{B}_{4} \mathrm{C} \quad$ Liquid pressing

The hybrid composite exhibited dynamic compressive strength over $1.5 \mathrm{GPa}$, along with a good total strain of $11.7 \%$ 
Table 4. (continued).

\begin{tabular}{|c|c|c|c|}
\hline Reinforcement & Production approach & Properties achieved & References \\
\hline $\mathrm{B}_{4} \mathrm{C}$ & $\begin{array}{l}\text { Blended powder } \\
\text { semisolid forming }\end{array}$ & $\begin{array}{l}\text { Composites with } 20 \mu \mathrm{m} \text { AA } 7075 \text { and } 20 \% \\
\text { (volume fraction) } 45 \mu \mathrm{m} \mathrm{B}_{4} \mathrm{C} \text { powder pressed } \\
\text { under } 100 \mathrm{MPa} \text { exhibited HV } 190 \text { and } \\
\text { compressive strength } 336 \mathrm{MPa}\end{array}$ & [85] \\
\hline $\mathrm{B}_{4} \mathrm{C}$ & Cryomilling & $\begin{array}{l}\text { The heat treated sample, with a high yield } \\
\text { strength, exhibits acceptable plasticity of } 11.7 \%\end{array}$ & {$[86]$} \\
\hline n-TiC & FSP & $\begin{array}{l}\text { Hardness is found to be reducing in the sintered } \\
\text { zone in all FSP samples }\end{array}$ & [91] \\
\hline $\mathrm{TiC}$ & $\begin{array}{l}\text { Laser shock peening } \\
\text { (LSP) and friction } \\
\text { stir welding (FSW) }\end{array}$ & $\begin{array}{l}\text { The CTE of composite decreased to } 17.1 \times 10^{6} \\
\mathrm{~K}^{-1} \text { by increasing the LSP impact times over a } \\
\text { wide temperature range from RT to } 300^{\circ} \mathrm{C} \text {. This } \\
\text { value was reduced by } 10 \% \text { compared with that } \\
\text { of the as-FSW } 7075 \mathrm{Al} \text { alloy }\end{array}$ & [93] \\
\hline $\mathrm{B}_{4} \mathrm{C}$ & $\begin{array}{l}\text { One step } \\
\text { consolidation }\end{array}$ & $\begin{array}{l}\text { The Vickers hardness, compressive yield strength } \\
\text { and fracture strength of the AA } 7075 / \mathrm{B}_{4} \mathrm{C} \\
\text { consolidated at } 450^{\circ} \mathrm{C} \text { were } 233 \mathrm{HV}, 724.9 \mathrm{MPa} \\
\text { and } 834.5 \mathrm{MPa} \text { respectively }\end{array}$ & [106] \\
\hline
\end{tabular}

concluded that composite processed through molten salt processing and undergone $\mathrm{T} 6$ treatment exhibited superior mechanical characteristics as compared to all other samples.

Sivasankaran et al. [24] have fabricated $\mathrm{TiB}_{2} / \mathrm{Gr}-$ Al7075 HMMCs by in-situ liquid metallurgy route. Their objective is to study sliding wear characteristics by response surface methodology. Reinforcing quantity of $\mathrm{TiB}_{2}$ is $0,1.5,3,4.5$ and $6 \%$ wt. while Gr was $1 \%$ wt. in the alloy. The test results showed that increase in both RF and SV percentages have reduced the wear loss curve, whereas the load at all sliding velocities and the sliding distances have increased the wear loss. Surface morphology of worn out specimen showed that the adhesive mechanisms were dominating during the wear test. Further, severe and mild wear occurred for higher and lower load respectively.

Liu et al. [25] developed HMMCs by dispersing $\mathrm{B}_{4} \mathrm{C}$ (4, 8 and $12 \%$ wt., $10 \mu \mathrm{m})$ and $\mathrm{MoS}_{2}(3 \%$ wt., $2 \mu \mathrm{m})$ in AA7075 matrix alloy by stir casting technique. They investigated compressive strength, tensile strength, hardness, microstructural analysis and tribological characteristics. By their study it has been observed that there is a noticeable improvement in resistance to wear and friction coefficient of AMMCs in comparison with base matrix.

Kumar Sahu and Kumar Sahu [26] synthesized AA7075- $\mathrm{B}_{4} \mathrm{C}$ and flyash composites by stir casting. The flyash (FA) quantity of $2 \% \mathrm{wt}$. is kept constant but $\mathrm{B}_{4} \mathrm{C}$ quantity is varied in the range $2-8 \%$ wt. in the matrix. The size of the reinforcements used were in the range 3-10 $\mu \mathrm{m}$. The composite with $2 \%$ wt. flyash and $8 \%$ wt. of $\mathrm{B}_{4} \mathrm{C}$ exhibited excellent value of microhardness and was $37.2 \%$ greater than matrix alloy. Also these authors observed that the addition of $\mathrm{B}_{4} \mathrm{C}$ and flyash in the $\mathrm{Al}$ matrix resulted in an increase of microhardness of composite and it increases with the increase of $\mathrm{B}_{4} \mathrm{C}$ quantity in the matrix.
Prabhu et al. [28] have tried to understand the effect of flyash and $\mathrm{Al}_{2} \mathrm{O}_{3}$ particulates on wear and tensile properties of AA7075 composites. The combined quantity of reinforcements considered is $5,10,15$ and $20 \%$ wt. The wear tests are performed at 10,20,40,80 N loads, sliding speed of $1.45 \mathrm{~m} / \mathrm{s}$ and sliding distance of $500 \mathrm{~m}$. It is found that wear resistance of the composite increases with the addition of $\mathrm{Al}_{2} \mathrm{O}_{3}$ and flyash. Enhanced resistance to wear is noticed for composite with $10 \%$ wt. $\mathrm{Al}_{2} \mathrm{O}_{3}$ and $10 \%$ wt. flyash composite.

Suresh et al. [29] used stir casting to produce AA7075$\mathrm{Al}_{2} \mathrm{O}_{3} / \mathrm{Mg}$ composites to study their mechanical properties. Alumina particles were in the size range $20-30 \mathrm{~nm}$. The quantity of alumina dispersed was 1, 2, 3 and $4 \%$ wt. Also $1 \% \mathrm{wt}$. $\mathrm{Mg}$ was added for improving the wettability between alumina and matrix. The results indicated that heat treatment process increased the mechanical properties of nano aluminium oxide composites when compared to as-cast. By increasing the wt.\% of nano-reinforcement the density decreased when compared to base alloy. The tensile strength, hardness, and toughness gradually improved by increasing weight $\%$ of $\mathrm{Al}_{2} \mathrm{O}_{3}$.

Suresh et al. [30] have developed $\mathrm{AA} 7075-\mathrm{Al}_{2} \mathrm{O}_{3} / \mathrm{SiC} /$ $\mathrm{Mg}$ by stir casting. The quantity of reinforcement taken in composites was $1,2,3$, and $4 \%$ wt. of $\left(\mathrm{Al}_{2} \mathrm{O}_{3}+\mathrm{SiC}\right)$ and $1 \%$ wt. Mg. The $\mathrm{Al}_{2} \mathrm{O}_{3}$ had size range $20-30 \mathrm{~nm}$ and $\mathrm{SiC} 50 \mathrm{~nm}$. The mechanical characteristics of MMCs such as tensile strength, compression strength, and hardness test are performed on the produced composites. The microhardness, compression strength, and tensile strength of AA7075 observed to have increased by incorporating $\mathrm{Al}_{2} \mathrm{O}_{3}$ and $\mathrm{SiC}$ reinforcements. Also it is noted that there is a decrease in coefficient of friction and wear rates with the increment in wt.\% of reinforcement.

Smart et al. [35] have fabricated composites by reinforcing $\mathrm{TaC}, \mathrm{Si}_{3} \mathrm{~N}_{4}$ and $\mathrm{Ti}$ in AA7075 alloy. The fabrication approach adapted by these researchers was stir 
Table 5. Properties of composites based on oxides.

\begin{tabular}{|c|c|c|c|}
\hline Reinforcement & Production approach & Properties achieved & References \\
\hline $\mathrm{n}-\mathrm{Al}_{2} \mathrm{O}_{3}$ & Ultrasonic vibration & $\begin{array}{l}\text { Compared to the hardness of } \mathrm{AA} 7075 \\
\text { (VHN94.7), the hardness of } \mathrm{Al}_{2} \mathrm{O}_{3} / 7075 \\
\text { composites (VHN113.8) increased by } \\
\text { nearly } 20 \% \text {. } \\
\text { Compared to the hardness of } \mathrm{Al}_{2} \mathrm{O}_{3} / 7075 \\
\text { composites (VHN } 113.8 \text { ), the hardness of } \\
\mathrm{Al}_{2} \mathrm{O}_{3} / 7075 \text { composites under solution } \\
\text { treatment (VHN150.4) at } 480^{\circ} \mathrm{C} \text { for } 5 \mathrm{~h} \\
\text { increased by nearly } 32 \% \text {. } \\
\text { Hardness of } \mathrm{Al}_{2} \mathrm{O}_{3} / 7075 \text { composites under } \\
\text { optimum T6 heat treatment (VHN173.5) } \\
\text { increased by nearly } 52 \%\end{array}$ & [81] \\
\hline $\mathrm{Al}_{2} \mathrm{O}_{3}$ & Squeeze casting & $\begin{array}{l}\text { The hardness of the composite is } 59 \mathrm{HRB} \text {. } \\
\text { The compressive strength is } 587 \mathrm{MPa}\end{array}$ & {$[82]$} \\
\hline $\mathrm{ZrO}_{2}$ & $\mathrm{PM}$ & $\begin{array}{l}\text { By the planetary ball mill, a full dispersion of } \\
\text { the } \mathrm{ZrO}_{2} \text { through the matrix is achieved. } \\
\text { In the case of the Simoloyer mill, the results } \\
\text { showed that there was not a fine dispersion } \\
\text { of the } \mathrm{ZrO}_{2} \text {. particles. } \\
\text { The shaker mill produced the best results, } \\
\text { because full dispersion of the } \mathrm{ZrO}_{2} \text { particles } \\
\text { took place in a homogeneous way in half the } \\
\text { time taken by the other mills tested }\end{array}$ & {$[90]$} \\
\hline
\end{tabular}




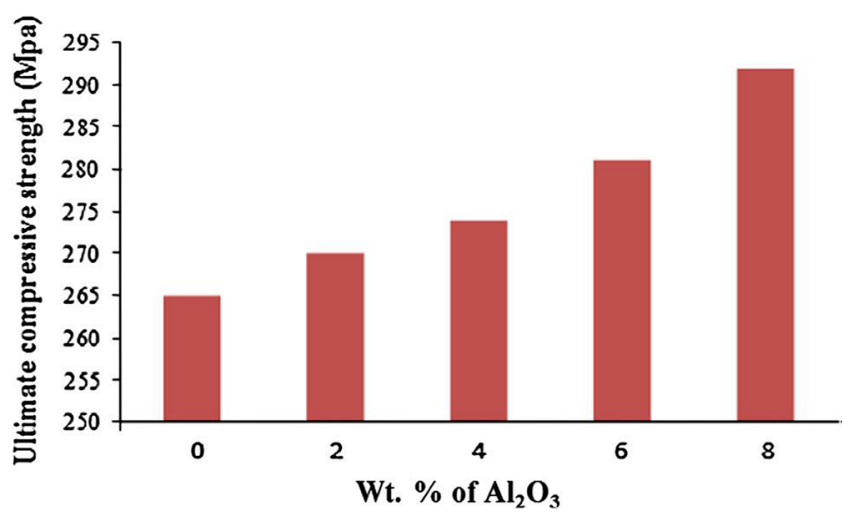

(i)

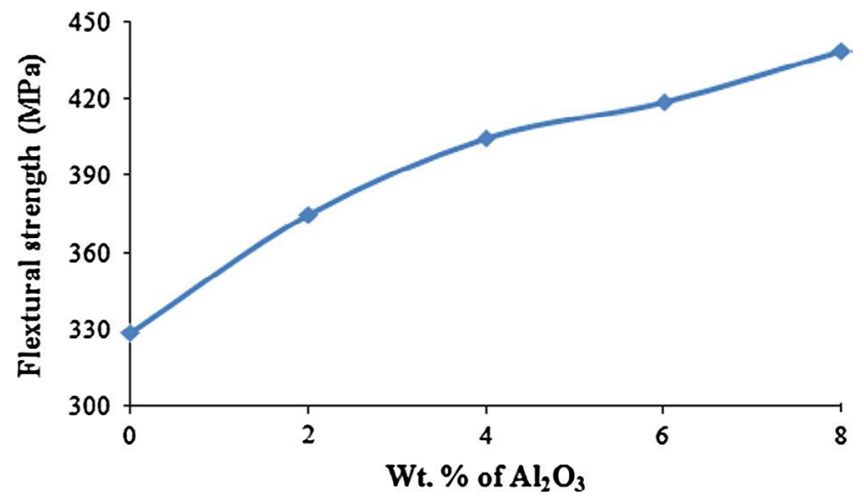

(ii)

Fig. 14. (i \& ii): Variation of ultimate compressive strength and flexural strength of composites with the quantity of $\mathrm{Al}_{2} \mathrm{O}_{3}$ respectively [83].

casting. They studied microstructural, mechanical and wear characteristics of the developed composites. The results of their study revealed that highest compression strength was $634 \mathrm{MPa}$ at $1 \%$ wt. of $\mathrm{TaC}$ and $8 \%$ wt. of $\mathrm{SiN}_{3} \mathrm{~N}_{4}$ and $2 \%$ wt. of $\mathrm{Ti}$ in hybrid composite. The results portrayed that the wear rate and coefficient of friction of HMMCs are lesser than that of the pure AA7075 alloy and later diminishes with rising $\mathrm{TaC} / \mathrm{Si}_{3} \mathrm{~N}_{4} / \mathrm{Ti}$ content.

Suganeswaran et al. [40] have studied the influence of secondary phase particles $\mathrm{Al}_{2} \mathrm{O}_{3} / \mathrm{SiC}$ on the microstructure and tribological characteristics of AA7075 based surface hybrid composites fabricated through friction stir processing. The study results showed that addition of $3.7 \%$ wt. $\mathrm{Al}_{2} \mathrm{O}_{3}+3.0 \%$ wt. SiC in AA7075 enhanced the microhardness about $33.96 \%$ higher than base matrix. Hence, wear resistance of the specimen is improved.

Ramadoss et al. [42] have done the synthesis of $\mathrm{B}_{4} \mathrm{C}$ and $\mathrm{BN}$ reinforced AA7075 hybrid composites using stir casting method. $\mathrm{B}_{4} \mathrm{C}$ was varied as 3, 6 and $9 \%$ wt. and $\mathrm{BN}$ was kept constant as $3 \%$ wt. The results of their study indicated that the hardness increased with the addition of reinforcements as compared to alloy. Also the composites have shown a maximum of $22 \%$ more strength as compared to bare alloy, and the corrosion rate decreased by $18.5 \%$ between 3 and $6 \%$ wt. boron carbide addition whereas it decreased by $22.4 \%$ between 6 and $9 \%$ wt. boron carbide addition.

Verma and Vettivel [46] have dispersed $\mathrm{B}_{4} \mathrm{C}$ and rice husk ash (RHA) in AA7075 matrix with $5 \%$ wt. $\mathrm{B}_{4} \mathrm{C}$ and $3,5 \%$ wt. of ash by using stir casting method. They tested composite and alloy for hardness, tensile and compression behaviours. The results of these tests indicated that composites displayed superior mechanical behavior in comparison to bare alloy.

Rajesh et al. [68] have worked towards material characterization of $\mathrm{SiC}$ and $\mathrm{Al}_{2} \mathrm{O}_{3}$ particulates dispersed AA7075 MMCs. Composites are produced by stir casting with $\mathrm{SiC}$ and alumina as reinforcement $(5,10$, and $15 \%$ wt. each). Wear test is conducted in a pin-on-disc device at room temperature for both post aging and pre aging states. This study showed that the improvement in resistance to wear is because of higher quantity of reinforcements in the matrix. By increasing the sliding speeds and sliding distance, a reduction in the rate of wear is observed. Higher quantity reinforcement composites showed lesser wear rate.

Liu et al. [69] produced $\left(\mathrm{SiC}_{\mathrm{p}}+\mathrm{Ti}\right) / 7075$ hybrid MMCs and $\mathrm{SiC}_{\mathrm{p}} / 7075$ MMCs. Their main focus of study is to investigate the effect of $\mathrm{Ti}$ on aging behavior and mechanical properties of composites. Composites in this research is produced by squeeze casting process. Quantity of $\mathrm{SiC}$ particles is $40 \%$ vol. with $7 \mu \mathrm{m}$ and $\mathrm{Ti}$ was $5 \%$ vol. with $35 \mu \mathrm{m}$. After aging heat treatment under the optimum conditions, the tensile strength of both composites is improved due to precipitation hardening of the matrix alloy. Ductility of composite containing $\mathrm{Ti}$ particles is improved because of the strengthened interfaces between the $\mathrm{Ti}$ particles and the matrix alloy.

Rama Kanth et al. [70] employed stir casting technique and developed flyash and $\mathrm{SiC}$ particles (53 $\mu \mathrm{m}$ both) reinforced Al-Zn alloy-based MMCs. The flyash and SiC reinforcement quantity varied in the range $0-15 \%$ wt. The results of experiments showed that the dispersion of flyash and $\mathrm{SiC}$ particles improved the hardness and tensile properties.

Boobesh Nathan et al. [72] reinforced $\mathrm{SiC}(2,4$ and $6 \%$ wt. $)$ and $\mathrm{ZrO}_{2}$ (3 \%wt.) by stir casting technique. These investigators have studied the mechanical and metallurgical properties of the produced composites. The researchers observed that the properties like hardness, impact energy, tensile strength and compressive strength increases with increase in quantity of reinforcements.

Bhowmik et al. [74] have fabricated AA7075-SiC and AA7075-TiB 2 MMCs for making comparative study of microstructure, physical and mechanical properties of these materials. Stir casting is used by these researchers to produce the materials. The results showed that $\mathrm{TiB}_{2}$ reinforced composite acquired $3.29 \%$ higher strength and $4.93 \%$ higher hardness compared to $\mathrm{SiC}$ reinforced composite.

Gorshenkov et al. [78] in 2012 have investigated the dry sliding friction characteristics of AA7075/h-BN (40\%vol.), $\mathrm{Al} 7075 / \mathrm{B}$ amorphous (30\%vol.) and AA7075/B $\mathrm{B}+\mathrm{W}(20$ $\%$ vol. $+2 \%$ vol. $)$ composites. These composites are fabri- 


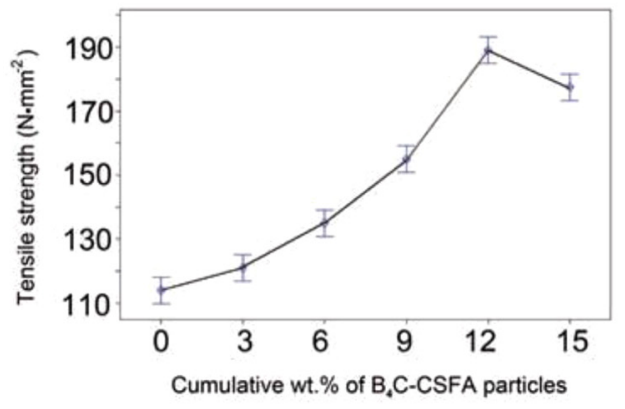

(i)

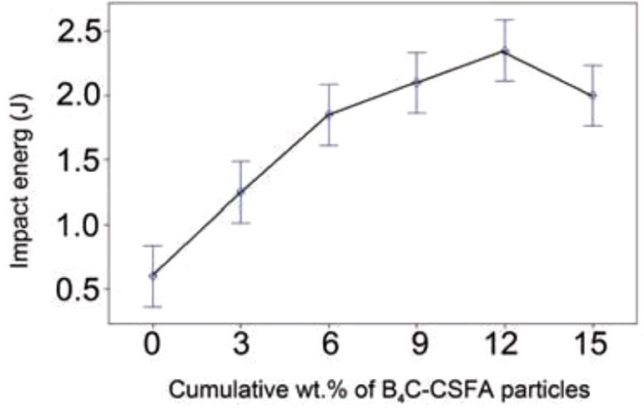

(ii)

Fig. 15. (i \& ii): Dependency of tensile strength and impact energy of composites on the quantity of reinforcements respectively [87].

cated by vacuum impregnation technology, explosive pressing, and mechanical alloying followed by hot extrusion. By experimentation it is observed that superior antifriction properties and resistance to wear for composite containing $\mathrm{B}_{4} \mathrm{C}$ and tungsten nanoparticles as compared to matrix alloy and composites with h-BN and amorphous boron.

Baradeswaran and Elaya Perumal [83] developed AA7075- $\mathrm{Al}_{2} \mathrm{O}_{3}$ /graphite HMMCs by stir casting technique with $5 \%$ wt. graphite particles addition and 2, 4, 6 and $8 \%$ wt. of $\mathrm{Al}_{2} \mathrm{O}_{3}$. The composite is given a $\mathrm{T} 6$ heat treatment and the specimens are tested for hardness, tensile strength, compressive strength, flexural strength and wear test. The hardness of composites is observed to increase due to increasing $\mathrm{Al}_{2} \mathrm{O}_{3}$ quantity and it is noticed to be higher than that of base alloy in all categories of specimens. Addition of $\mathrm{Al}_{2} \mathrm{O}_{3}$ particle increased the tensile strength, compression strength (Fig. 14(i)) and flexural strength (Fig. 14(ii)) of the hybrid composite and it is again higher than that of base alloy. It is concluded that the presence of graphite in the composites has reduced wear, because of formation of thin layer of graphite on the tribo surface. Also graphite has reduced the friction coefficient of the hybrid composite.

Rakshath et al. [84] have used alumina and hexagonal boron nitride as fillers with AA7075 alloy. They have used two step stir casting method and formulation of the composites are 2.5 and $5 \%$ wt. particulates. The objective of their study is to understand dry sliding and abrasive wear behavior of alloy and composites. Mechanical and dry sliding wear test results indicated that both alumina and hBN fillers show improved mechanical properties and wear resistance. Wear resistance of composites is increased by increasing the weight percentage of reinforcements and the reinforced composite gave better resistance against abrasion than the control sample (AA7075). Also $5 \%$ wt. micro h-BN reinforced AA7075 composite prompted a predominant abrasion resistance.

Subramaniam et al. [87] fabricated and evaluated mechanical properties of composites consisting of $\mathrm{B}_{4} \mathrm{C}$ $(0,3,6,9$ and $12 \%$ wt.; $75 \mu \mathrm{m})$ and coconut shell flyash (3\%wt.) as reinforcements and AA7075 as matrix material. These have adapted stir casting process for producing the composites. The experimentation in their work showed that hardness, tensile strength (Fig. 15(i)) and impact strength (Fig. 15(ii)) of composites are superior as that of alloy.

Pratheep Reddy et al. [88] developed 7075/ $\mathrm{B}_{4} \mathrm{C} /$ flyash composites to study the dry sliding wear behavior in Pinon-disc machine. The quantity of reinforcement is varied in the range 1-4\%wt. in steps of 1 and flyash in the range 6-9 $\%$ wt. in steps of 1 . Their results indicated that AA7075/ $\mathrm{B}_{4} \mathrm{C} /$ flyash composites with wt. $\%$ (90:3:7) exhibited superior wear performance.

Vignesh Kumar et al. [89] in their study have fabricated $\mathrm{AA} 7075-\mathrm{B}_{4} \mathrm{C} / \mathrm{BN}$ by stir casting method. The prime focus of the study is to evaluate thrust force and perform microstructure characterization of composites. The reinforcing particles are of $1 \mu \mathrm{m}$ size and the weight percentage of $\mathrm{BN}$ is kept constant of 3 and $\mathrm{B}_{4} \mathrm{C}$ is varied from $3-9$ insteps of 3 . Their results showed that feed and point angle are the highly influential parameters for thrust force and surface roughness of the prepared HMMCs.

Sasikumar et al. [94] studied the kerf characteristics while abrasive jet machining of the composites made by reinforcing $\mathrm{TiC}$ and $\mathrm{B}_{4} \mathrm{C}$ in 7075 aluminium alloy matrix. The kerf characteristics such as kerf top width, kerf angle and surface roughness are investigated against the abrasive water jet machining process parameters, namely, water jet pressure, jet traverse speed and standoff distance.

Dhulipalla et al. [95] in their investigation have reinforced $\mathrm{TiC}$ ceramic and $\mathrm{MoS}_{2}$ soft particulates in AA7075 matrix by stir casting technique. They studied the machinability characteristics of the composite. The results of their study indicated that the aluminium composites exhibited excellent machinability in comparison to the base AA7075. The chip morphology has transformed from continuous sheared in AA7075 to discontinuous in composites. The transformation is brought out by the decreased ductility in composite because $\mathrm{TiC}$ and $\mathrm{MoS}_{2}$ micro reinforcements. The surface roughness has increased for the AMCs when compared to that of base alloy due to hard $\mathrm{TiC}$ particles.

Rama Kanth et al. [107] have studied mechanical behaviour of flyash/SiC particles reinforced in AA7075 alloy matrix composites. The reinforcements were of $53 \mu \mathrm{m}$ and the combined quantity is 5 and $10 \%$ wt. in $1: 1$ proportion. Their results showed that with increase in 
Table 6. Properties of HMMCs investigated.

\begin{tabular}{|c|c|c|c|}
\hline Reinforcement & $\begin{array}{l}\text { Production } \\
\text { approach }\end{array}$ & Properties achieved & References \\
\hline $\mathrm{SiC} / \mathrm{Al}_{2} \mathrm{O}_{3}$ & $\begin{array}{l}\text { Inert gas assisted } \\
\text { electromagnetic } \\
\text { stir casting process }\end{array}$ & $\begin{array}{l}\text { The pulse on time in EDM was the most significant } \\
\text { parameter that contributed maximum of } 46.04 \% \text { to } \\
\text { the } \\
\text { MRR followed by pulse current of } 34.72 \% \text {, pulse off } \\
\text { time of } 10.23 \% \text { and interaction, pulse on time } 3 \\
\text { pulse } \\
\text { off time of } 5.46 \% \text {. } \\
\text { The wire drum speed had insignificant effect on the } \\
\text { material removal rate }\end{array}$ & {$[7]$} \\
\hline $\mathrm{Al}_{2} \mathrm{O}_{3}$, h-BN particles & $\begin{array}{l}\text { Ultrasonic assisted } \\
\text { cavitation and } \\
\text { molten salt } \\
\text { processing } \\
\text { methods }\end{array}$ & $\begin{array}{l}\text { Deep cycle cryogenic treatment (DCT) } \mathrm{T}_{6} \\
\text { treatment is observed to elevate mechanical } \\
\text { properties to a greater extent. } \\
\text { Under T6 condition, the VHN is improved to the } \\
\text { maximum of } 44.1 \% \text { in unreinforced aluminium alloy } \\
\text { and } 39.6 \% \text { in case of the hybrid nanocomposite, } \\
\text { while the corresponding improvement of } 5.1 \% \text { and } \\
4.5 \% \text { is observed under DCT }\end{array}$ & {$[21]$} \\
\hline $\mathrm{TiB}_{2} / \mathrm{Gr}$ & $\begin{array}{l}\text { In-situ liquid } \\
\text { metallurgy route }\end{array}$ & $\begin{array}{l}\text { By investigation it is found that } \mathrm{TiB}_{2} \text { particles were } \\
\text { pinned the matrix grain growth while casting itself } \\
\text { which acted as the grain refiner. } \\
\text { ANOVA results were showed that the sliding } \\
\text { distance was had more influence on the wear rate } \\
\text { followed by the load }\end{array}$ & {$[24]$} \\
\hline $\mathrm{B}_{4} \mathrm{C}$ and $\mathrm{MoS}_{2}$ & Stir casting & $\begin{array}{l}\text { Wear loss of AA7075 }+12 \% \mathrm{~B}_{4} \mathrm{C}+3 \% \mathrm{MoS}_{2} \text { is } \\
\text { found to be } 0.0387 \mathrm{~g} \text { at } 30 \mathrm{~N} \text { load, tensile strength } \\
298.52 \mathrm{~N} / \mathrm{mm}^{2} \text {, yield strength } 172.6 \mathrm{~N} / \mathrm{mm}^{2} \text { and } \\
\text { elongation } 3.7 \% \text {, hardness } 94.32 \mathrm{VHN}\end{array}$ & {$[25]$} \\
\hline $\mathrm{Al}_{2} \mathrm{O}_{3} / \mathrm{Mg}$ & Stir casting & $\begin{array}{l}\text { By increasing the wt. } \% \text { of nano-reinforcement the } \\
\text { density decreased when compared to base alloy. } \\
\text { Tensile strength, hardness, and toughness gradually } \\
\text { improved by increasing wt. } \% \text { of } \mathrm{Al}_{2} \mathrm{O}_{3}\end{array}$ & {$[29]$} \\
\hline $\mathrm{Al}_{2} \mathrm{O}_{3} / \mathrm{SiC} / \mathrm{Mg}$ & Stir casting & $\begin{array}{l}\text { The compressive strength, ultimate tensile } \\
\text { strength, and hardness values increase by } \\
\text { increasing the weight percentage of nano- } \mathrm{Al}_{2} \mathrm{O}_{3} \text { and } \\
\text { n-SiC reinforcement. } \\
\text { HMMCs exhibited a significant decrease in friction } \\
\text { coefficient and wear rates with an increase in the } \\
\text { wt. } \% \text { of reinforcement particles }\end{array}$ & {$[30]$} \\
\hline $\mathrm{TaC} / \mathrm{Si}_{3} \mathrm{~N}_{4} / \mathrm{Ti}$ & Stir casting & $\begin{array}{l}\text { Combined } \mathrm{TaC} / \mathrm{Si}_{3} \mathrm{~N}_{4} / \mathrm{Ti} \text { reinforcements with in } \\
\text { AA } 7075 \text { elevated the mechanical properties. } \\
\text { Theoretical and experimental densities were noted } \\
\text { to be } 3.11 \mathrm{~g} / \mathrm{cc} \text { and } 3.09 \mathrm{~g} / \mathrm{cc} \text { as compared to the } \\
\text { density of base alloy. However, the highest } \\
\text { compression strength was } 634 \mathrm{MPa} \text { at } 1 \mathrm{wt} . \% \text { of } \\
\text { TaC and } 8 \mathrm{wt} \% \text { of } \mathrm{Si}_{3} \mathrm{~N}_{4} \text { and } 2 \mathrm{wt} . \% \text { of Ti in hybrid } \\
\text { composite }\end{array}$ & {$[35]$} \\
\hline
\end{tabular}


Table 6. (continued).

\begin{tabular}{|c|c|c|c|}
\hline Reinforcement & $\begin{array}{l}\text { Production } \\
\text { approach }\end{array}$ & Properties achieved & References \\
\hline
\end{tabular}

$\mathrm{Al}_{2} \mathrm{O}_{3} / \mathrm{SiC} \quad \mathrm{FSP}$

Addition of 3.7 wt. $\% \quad \mathrm{Al}_{2} \mathrm{O}_{3}+3.0 \mathrm{wt} . \% \quad \mathrm{SiC}$ in AA7075 enhanced the micro hardness about $33.96 \%$ which is higher than base matrix.

Specimen with $3.7 \% \mathrm{Al}_{2} \mathrm{O}_{3}+3.0 \% \mathrm{SiC}$ has better lubrication and load-bearing capacity that exhibited superior tribological characteristics at 40 and $60 \mathrm{~N}$

$\mathrm{B}_{4} \mathrm{C}$ and $\mathrm{BN} \quad$ Stir casting

$\mathrm{B}_{4} \mathrm{C}$ and Rice husk $\quad$ Stir casting ash (RHA)

$\mathrm{SiC}$

and $\mathrm{Al}_{2} \mathrm{O}_{3}$

Stir casting

$\mathrm{SiC}_{\mathrm{p}}, \mathrm{Ti}$

Squeeze-casting

Fly ash $/ \mathrm{SiC}$

$\mathrm{SiC} / \mathrm{TiB}_{2}$

h-BN, $\mathrm{B}_{4} \mathrm{C}$ and amorphous B

$\mathrm{Al}_{2} \mathrm{O}_{3} /$ graphite
Stir casting

Vacuum impregnation technology, explosive pressing, and mechanical alloying with subsequent hot extrusion Stir casting
Dispersion of $\mathrm{B}_{4} \mathrm{C}$ and $\mathrm{BN}$ to alloy has raised the strength by $22 \%$.

The corrosion rate decreased by $18.5 \%$ between $3 \%$ and $6 \% \mathrm{~B}_{4} \mathrm{C}$ addition whereas it decreased by $22.4 \%$ between $6 \%$ and $9 \% \mathrm{~B}_{4} \mathrm{C}$ addition

The hardness for AA $7075-5 \% \mathrm{~B}_{4} \mathrm{C}-5 \% \mathrm{RHA}$ is 121 $\mathrm{HV}$, tensile strength is $260 \mathrm{MPa}$ at 5 wt. $\%$ of $\mathrm{B}_{4} \mathrm{C}$. The compression strength is $563 \mathrm{MPa}$ at 5 wt.\% of $\mathrm{B}_{4} \mathrm{C}$ and 5 wt.\% of RHA in hybrid composite

By raising the sliding speeds, there is a reduction in the wear rate and it decreases with increase in the sliding distance. With increasing weight fraction, there is decrement in the rate of wear of composites.

Tensile properties:

$7 \mathrm{vol} \% \mathrm{SiC} / \mathrm{Al}$ composite (unreacted interface)- $\sigma_{\mathrm{y}}$ $\sim 97 \mathrm{MPa}, \sigma_{\max } \sim 113 \mathrm{MPa}$, elongation $\sim 16 \%$.

$7 \mathrm{vol} \% \mathrm{SiC} / \mathrm{Al}$ composite (reacted interface)- $\sigma_{\mathrm{y}}$ $\sim 103 \mathrm{MPa}, \sigma_{\max } \sim 139 \mathrm{MPa}$, elongation $\sim 14 \%$.

As cast with Ti particle (diffusion layer)- $\sigma_{\mathrm{y}}$ $\sim 523 \mathrm{MPa}, \sigma_{\max } \sim 622 \mathrm{MPa}$, elongation $\sim 1.2 \%$.

As cast with Ti particle (diffusion \& reaction layer)- $\sigma_{\mathrm{y}} \sim 539 \mathrm{MPa}, \sigma_{\max } \sim 673 \mathrm{MPa}$, elongation $\sim 1.6 \%$.

$10 \%$ fly ash/SiC-142 VHN, UTS $>210 \mathrm{MPa}$, YS $>150 \mathrm{MPa}$.

$5 \%$ fly ash/SiC-120 VHN, UTS $\sim 200 \mathrm{MPa}$, $\mathrm{YS} \sim 150 \mathrm{MPa}$

Alloy-102 VHN, UTS $\sim 180 \mathrm{MPa}$, YS $\sim 140 \mathrm{MPa}$

UTS and micro hardness of $\mathrm{Al}$ composite is $182 \mathrm{MPa}$ and $81 \mathrm{HV}$ respectively

AA7075-HRB $<5$, density $2.85 \mathrm{~g} / \mathrm{cc}$, wear 55.3 microns.

AA7075/B-amorphous-HRB 86, density $2.39 \mathrm{~g} / \mathrm{cc}$, wear 7.2 microns.

AA7075/h-BN-HRB 85, density $2.30 \mathrm{~g} / \mathrm{cc}$, wear 3.3 microns.

$\mathrm{AA} 7075 / \mathrm{B}_{4} \mathrm{C}+\mathrm{W}-\mathrm{HRB} \sim 75$, density $2.87 \mathrm{~g} / \mathrm{cc}$, wear 6.4 microns

Hardness, tensile strength, flexural strength of the hybrid composites increased with increasing $\mathrm{Al}_{2} \mathrm{O}_{3}$ particulates.

Graphite decrease the hardness, tensile strength, compression strength and flexural strength and it was overcome by the addition of $\mathrm{Al}_{2} \mathrm{O}_{3}$ particulates in the hybrid composites. 
Table 6. (continued).

\begin{tabular}{|c|c|c|c|}
\hline Reinforcement & $\begin{array}{l}\text { Production } \\
\text { approach }\end{array}$ & Properties achieved & References \\
\hline & & $\begin{array}{l}\text { The presence of graphite in the hybrid composite as } \\
\text { also been able to decrease the wear and coefficient } \\
\text { of friction of the composite }\end{array}$ & \\
\hline $\begin{array}{l}\mathrm{B}_{4} \mathrm{C}-\mathrm{Coconut} \text { shell } \\
\text { fly } \operatorname{ash}(\mathrm{CSFA})\end{array}$ & Stir casting & $\begin{array}{l}\text { Hardness of the composites increased } 33 \% \text { by } \\
\text { reinforcements of } 12 \mathrm{wt} . \% \mathrm{~B}_{4} \mathrm{C} \text { and } 3 \mathrm{wt} . \% \mathrm{CSFA} \text { in } \\
\text { aluminium } 7075 \text { alloy. The tensile strength of the } \\
\text { composites increased } 66 \% \text { by the addition of } 9 \mathrm{wt} . \% \\
\mathrm{~B}_{4} \mathrm{C} \text { and } 3 \mathrm{wt} . \% \mathrm{CSFA} \text { in aluminium } 7075 \text { alloy. } \\
\text { The impact energy of the composites increased up } \\
\text { to } 2.3 \mathrm{~J} \text { with } 9 \mathrm{wt} . \% \mathrm{~B}_{4} \mathrm{C} \text { and } 3 \mathrm{wt} . \% \text { CSFA addition } \\
\text { in aluminium alloy }\end{array}$ & {$[87]$} \\
\hline $\mathrm{B}_{4} \mathrm{C} / \mathrm{fly}$ ash & Stir casting & $\begin{array}{l}\text { Mechanical and tribological properties are } \\
\text { improved for } \mathrm{Al} 7075 \mathrm{wt} \% 90, \mathrm{~B}_{4} \mathrm{C} \text { wt. } \% 3 \text {, and fly } \\
\text { ash wt. } \% 7 \text { as } 111 \mathrm{BHN} \text {, UTS is } 290 \mathrm{MPa}, \% \\
\text { elongation } 0.75 \mathrm{~mm} \text {, impact strength } 0.76 \mathrm{~J} \text {, and } \\
\text { wear rate } 1.4 \mathrm{~mm}^{3} / \mathrm{min}\end{array}$ & {$[88]$} \\
\hline $\mathrm{B}_{4} \mathrm{C} / \mathrm{BN}$ & $\begin{array}{l}\text { Casting } \\
\text { technique }\end{array}$ & $\begin{array}{l}\text { Density of the prepared composites was notably } \\
\text { increased with the addition of } \mathrm{B}_{4} \mathrm{C} \text { and } \mathrm{BN} \\
\text { particles. For MMC UTS, yield strength and } \\
\text { hardness, were } 57,44 \text { and } 72 \% \text { higher than alloy } \\
\text { matrix }\end{array}$ & [89] \\
\hline $\begin{array}{l}\mathrm{TiC} \text { ceramic and } \\
\mathrm{MoS}_{2}\end{array}$ & Stir casting & $\begin{array}{l}\text { The measured Rockwell Hardness }(\mathrm{HRB}) \text { values are } \\
52.5 \pm 1.5(\mathrm{AA} 7075), 67.2 \pm 2.2(\mathrm{Al}+\mathrm{TiC}(2 \%)) \\
75.4 \pm 4.3(\mathrm{Al}+\mathrm{TiC}(4 \%)), 54.1 \pm 2.4(\mathrm{Al}+\mathrm{TiC} \\
\left.(2 \%)+\mathrm{MoS}_{2}(2 \%)\right) \text {, and } 61.9 \pm 6.6(\mathrm{Al}+\mathrm{TiC}(4 \%) \\
\left.+\mathrm{MoS}_{2}(2 \%)\right) \text {. } \\
\text { The surface roughness increased from } 0.15 \sim 0.35 \\
\text { microns for AA7075;0.38 } 0.46 \text { microns for } \\
\text { AA7075 }+\mathrm{TiC}(2 \%)+\mathrm{MoS}_{2}(2 \%) ; \text { and } 0.54 \sim 0.62 \\
\text { AA7075 }+\mathrm{TiC}(4 \%)+\mathrm{MoS}_{2}(2 \%)\end{array}$ & [95] \\
\hline $\begin{array}{l}\mathrm{TiB}_{2}, \mathrm{Al}_{2} \mathrm{O}_{3}, \mathrm{Mg} \text {, and } \\
\mathrm{Zn}\end{array}$ & FSP & $\begin{array}{l}\text { The results indicate that poor bonding between the } \\
\text { reinforcement-matrix significantly reduces strength } \\
\text { and wear behaviors. } \\
\text { The effective dispersion of reinforcement results in } \\
\text { net enhancement in strength and wear performance } \\
\text { both when the processing done within a specific } \\
\text { range of processing time-temperature }\end{array}$ & {$[108]$} \\
\hline
\end{tabular}

quantity of the reinforcements there is improvement in hardness, tensile strength and flexural strength of composites as compared to the base alloy.

Gangil et al. [108] have adapted friction stir processing to produce the surface composites with a mixture of reinforcements that included $\mathrm{TiB}_{2}, \mathrm{Al}_{2} \mathrm{O}_{3}, \mathrm{Mg}$, and $\mathrm{Zn}$ in proportions of $66.5,22.5,6.5$ and 3.5 (in wt. \%) respectively. The base alloy used was AA7075. The objective of the study was to do microstructural characterization and understand tribological behavior of the composites. The results showed that the wear performance of all samples which are processed at large shoulder diameters has improved.

\subsubsection{Summary of the properties of AA7075 based hybrid composites}

The properties of HMMCs are listed in Table 6 .

\subsection{Research based on other compounds composites}

Deaquino-Lara et al. [5] have produced AA7075 and graphite $(0.5,1$ and $1.5 \%$ wt.) composites by milling process with subsequent hot extrusion. The mechanical properties of the alloy and composites are found out by tension tests and hardness measurements. It is discovered that as the content of graphite particles and milling time 


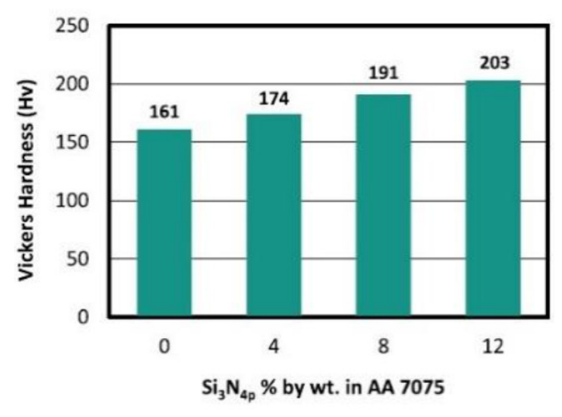

(i)

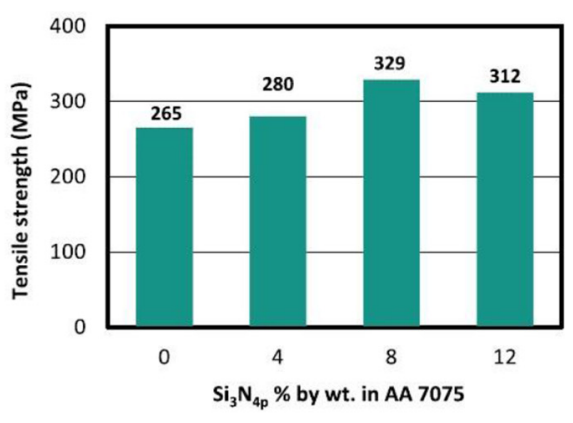

(ii)

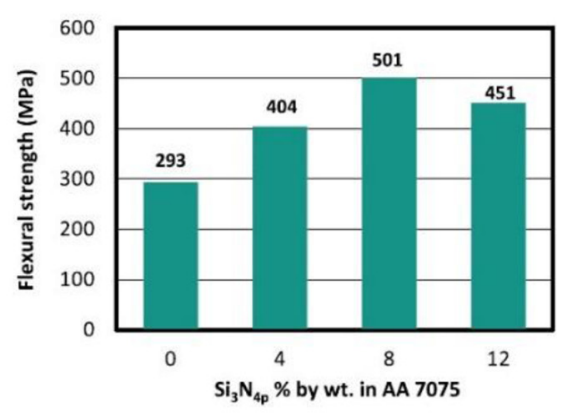

(iii)

Fig. 16. ((i), (ii) \& (iii)): Variation of hardness, tensile strength and flexural strength with quantity of reinforcements of composites respectively [101].

are increased correspondingly, the yield strength, the maximum strength and the Vicker's microhardness are increased, but the elongation is decreased noticeably in few specimens. Overall the mechanical properties of composites are higher as compared to alloy without graphite addition.

Tekiyeh et al. [23] developed carbon nanotube (CNT) reinforced AA7075 MMCs by FSP. The objective was to improve machinability characteristics of the produced composites. The thrust force and surface roughness were the two main criteria considered to study the machinability. The experimentation indicates that dispersion of CNT results in decrement of thrust force and surface roughness due to lubrication effect of CNT.

Suresh et al. [32] in their study have fabricated MWCNT reinforced AA7075 MMCs. The quantity reinforced was in the range $1-3 \%$ wt. in steps of 1 . They investigated mechanical, wear, and machining characteristics of composites. The results of this study indicated that the microhardness and tensile strength increase by 6 and $25 \%$ respectively. The wear rate and friction coefficient of composites have decreased by 39 and $48 \%$ respectively at a sliding speed of $3 \mathrm{~m} / \mathrm{s}$. Also, the metal removal rate has reduced by $40 \%$ and the surface roughness is improved by $38 \%$ respectively.

Manoj and Gadpale [38] produced AA7075-MoSi ${ }_{2}$ composites by stir casting. The purpose of their research is to study the dry sliding wear behavior of these composites. The reinforcements used are in the range $2-8 \mu \mathrm{m}$ and reinforcing quantity is $2,3,4$ and $5 \%$ wt. They observed that with increase in applied load, mode of material removal changes as ploughing, delamination, crater formation and plastically deformed layers. Amount of reinforcement and frictional heating affect the wear response of composites. With increase in applied load, wear resistance of composite has been found to be improved as compared to base alloy.

Loganathan et al. [39] have studied the influence of $\mathrm{ZrB}_{2} / \mathrm{hBN}$ particles on the wear response of AA7075 composites produced by stir and squeeze casting technique. $\mathrm{ZrB}_{2}$ and $\mathrm{hBN}$ at levels of $5 \%$ wt. were chosen as reinforcements for their investigation. The results of this study showed that $\mathrm{ZrB}_{2}$ particles reinforced composite displayed an improvement in hardness in comparison as-cast and composite containing $\mathrm{hBN}$.
Flores-Campos et al. [75], in 2010 have developed AA7075 matrix composites by reinforcing silver nanoparticles coated with carbon ( $\mathrm{Ag}-\mathrm{C}$ nano particles in the range $10-20 \mathrm{~nm}$ ) through the mechanical milling process. The reinforcement quantity in matrix is varied up to $2 \% \mathrm{wt}$. in steps of $0.5 \%$ wt. Microhardness of composites is observed to have increased with increase in milling time and the quantity of reinforcement. Concentrations of $\mathrm{Ag}-\mathrm{C}$ nano particles higher than $2 \%$ wt. is found to have no significant effect on microhardness.

Researchers from Mexico, Deaquino-Lara et al. [77] have fabricated AA7075 composites by reinforcing graphite particles (0-1.5 \%wt.) by employing mechanical alloying with subsequent hot extrusion. The influence of time for milling and the quantity of reinforcement on friction, hardness and wear are studied. Experimental results showed a significant improvement in composite hardness and wear resistance for $1.5 \%$ wt. of graphite and milling time of $10 \mathrm{~h}$. Composites also had a umiform distribution of the reinforcement particles in the matrix and the wear resistance of aluminum alloy followed a linear relation with (grain size)-1/2 which is similar to the Hall-Petch effect.

Wang et al. [97] studied elevated temperature ductility and fracture mechanisms of an in-situ particle reinforced $7075 \mathrm{Al}-\mathrm{TiB}_{2}$ composite. Their experimentation disclosed that the effect of temperature on ductility of the composite is more noticeable, while the effect on strain rate is very least. Also temperature has greater influence for increasing the ductility of the composite when it below $400{ }^{\circ} \mathrm{C}$ while there is a decrease in ductility above $400^{\circ} \mathrm{C}$. Also it is found that nucleation of voids and void growth is the primary mechanism of fracture the composite at elevated temperature.

Pan et al. [98] have tried to understand the tribological performance of composites with matrix as AA7075 alloy and reinforcements as $\mathrm{TiB}_{2}$. The composites in this work are fabricated by in-situ method. The produced composites are subjected to heat treatment and further they are tested for wear performance in Pin-on-disc apparatus. A new measurement method is applied in the tribological study to distinguish the contributions from pure friction and wear for AA7075 nanocomposites in this study. The investigators concluded that study is of significance for a rational design of AA7075 nanocomposites for optimized tribological performance. 
Table 7. Properties of HMMCs based on other compounds.

\begin{tabular}{lll}
\hline Reinforcement & Production approach & Pro \\
\hline Graphite & Milling processes and & y \\
& hot extrusion & a \\
& & e
\end{tabular}

MWCNT Stir casting

$\mathrm{MoSi}_{2}$

$\mathrm{ZrB}_{2} / \mathrm{hBN}$

Ag nanoparticles

Graphite

$\mathrm{TiB}_{2}$
Stir Casting

Stir-squeeze cast technique.

Mechanical milling

Mechanical alloying and hot extrusion

In-situ

In-situ
Properties achieved

References

yield strength, the maximum strength and the Vickers micro hardness were enhanced as a function of graphite particles content and milling time, but the elongation was reduced significantly in some cases

Micro hardness and tensile strength increase by $6 \%$ and $25 \%$.

The wear rate and coefficient of friction of composites are decreased by $39 \%$ and $48 \%$ at a sliding speed of $3 \mathrm{~m} / \mathrm{s}$.

In addition, the metal removal rate decreases by $40 \%$ and the surface roughness enhanced by $38 \%$ respectively

With increase in applied load, mode of material removal changes as ploughing, delamination, crater formation and plastically deformed layers.

Particle content and frictional heating affect the wear characteristics.

With increase in applied load, performance (wear resistance) of composite has been found to be improved when compared with that of the monolith The $\mathrm{ZrB}_{2}$ particles reinforced composite showed an improvement in hardness compared to as-cast and hBN containing composite.

A minor reduction in the hardness of $\mathrm{ZrB}_{2}-\mathrm{hBN}$ hybrid composite was observed Micro hardness increases as $\mathrm{Ag}-\mathrm{C}$ NP content increases.

Micro hardness increases in the nanocomposite as the milling time increases.

By combining nanoparticles dispersion and MM process it is possible to obtain better properties than those reached by T73 and T6 tempers in AA7075 alloy

Considerable improvement in MMC hardness and wear resistance by adding $1.5 \%$ graphite (wt.) and $10 \mathrm{~h}$ of milling, showed homogenous distribution of the reinforcement particles in the Al-based MMC The ductility of MMC rises with temperature in the range $350-400^{\circ} \mathrm{C}$, and reduces in the range $400-450 \mathrm{C}$

A A $7075-\mathrm{E} \sim 75 \mathrm{G} \mathrm{P}$ a, $\mathrm{M}$ o h s hardness $\sim 2.3 \mathrm{GPa}$, Vickers hardness $\sim 180$ VHN.

$\mathrm{AA} 7075+1.5$ vol\% $\mathrm{TiB}_{2}-\mathrm{E} \sim 80 \mathrm{GPa}$, Mohs hardness $\sim 3 \mathrm{GPa}$, Vickers hardness $\sim 200 \mathrm{VHN}$
[5]

[38]

[39]

[75] 
Table 7. (continued).

\begin{tabular}{|c|c|c|c|}
\hline$\underline{\text { Reinforcement }}$ & Production approach & Properties achieved & References \\
\hline $\mathrm{Si}_{3} \mathrm{~N}_{4}$ & Stir casting & $\begin{array}{l}\text { Increase in silicon nitride reinforcement } \\
\text { the micro hardness improved. } \\
\text { The micro hardness showed a decreasing } \\
\text { trend with the increase in indentation } \\
\text { load and a decreasing trend with the } \\
\text { increase in dwell time }\end{array}$ & {$[100]$} \\
\hline $\mathrm{Si}_{3} \mathrm{~N}_{4}$ & Stir casting & $\begin{array}{l}\text { Tensile strength and flexural strength of } \\
\mathrm{HT} \text { AMCs were increased up to } 8 \% \text { wt. } \\
\mathrm{Si}_{3} \mathrm{~N}_{4} \text { addition, but decreased at } 12 \% \text { wt. } \\
\mathrm{Si}_{3} \mathrm{~N}_{4} \text { addition in AA7075. } \\
\text { Wear loss of } 12 \% \text { wt. } \mathrm{Si}_{3} \mathrm{~N}_{4} \text { reinforced } \mathrm{HT} \\
\text { AMCs was decreased up to } 37.17 \% \text { as } \\
\text { compared to } \mathrm{HT} \text { AA } 7075 \text { matrix. } \\
\text { Whereas, COF of } 12 \% \text { wt. } \mathrm{Si}_{3} \mathrm{~N}_{4} \\
\text { reinforced HT AMCs was decreased up to } \\
11.03 \% \text { as compared to pure HT AA } 7075\end{array}$ & [101] \\
\hline $\mathrm{Si}_{3} \mathrm{~N}_{4}$ & Stir casting & $\begin{array}{l}\text { The presence of Porosity, consequently, } \\
\text { decreases most of the mechanical } \\
\text { properties of cast MMCs. } \\
\text { By means of heat treatment also we can } \\
\text { reduce porosity by heating the metal }\end{array}$ & {$[102]$} \\
\hline VN & $\begin{array}{l}\text { Ball milling and hot- } \\
\text { press sintering }\end{array}$ & $\begin{array}{l}\text { The hardness ( } 119.5 \mathrm{Hv}) \text { of } 15 \text { wt.\% VN/ } \\
7075 \text { composite was } 46.1 \% \text { higher than } \\
\text { the AA7075 alloy }(81.8 \mathrm{Hv}) \text {. } \\
\text { The friction coefficient of } 15 \text { wt. } \% \mathrm{VN} / \\
7075 \text { composite decreased by } 37.6 \% \\
\text { compared with the AA7075 alloy }\end{array}$ & {$[103]$} \\
\hline CNTs & $\mathrm{PM}$ & $\begin{array}{l}\text { After aging treatment, the CNTs } / 7075 \mathrm{Al} \\
\text { composites had the peak hardness of } \\
151.4 \mathrm{HV} \text {. } \\
\text { CNTs } / 7075 \mathrm{Al} \text { composites exhibited a } \\
\text { tensile strength of } 558.3 \mathrm{MPa} \text { and an } \\
\text { elongation of } 7.7 \%\end{array}$ & [104] \\
\hline
\end{tabular}

Zhao et al. [99] studied the particle dispersion and grain refinement of in-situ $\mathrm{TiB}_{2}$ particle reinforced AA7075 composite processed by elliptical cross-section torsion extrusion. A modified torsion extrusion (TE) method, entitled elliptical cross-section TE (E-TE), was proposed as a severe plastic deformation (SPD) process to refine the microstructures and improve the mechanical properties of a bulk in-situ $\mathrm{TiB}_{2}$ particle reinforced AA7075 composite. The results of the test indicates that proposed E-TE process thus can be used as an efficient process for optimizing mechanical properties of metal matrix composites.

Ul Haq and Anand [100] produced AA7075/ $\mathrm{Si}_{3} \mathrm{~N}_{4}$ composites by stir casting to study the microhardness. Silicon nitride is varied from $0-8 \%$ wt. in steps of 2 . The microstructure revealed a grain refinement with increase in the $\mathrm{Si}_{3} \mathrm{~N}_{4}$ quantity and improvement in microhardness. But microhardness decreased with the increase in indentation load and increase in dwell time.
Mistry and Gohil [101] in their work have reinforced $\mathrm{Si}_{3} \mathrm{~N}_{4}$ by varying it from 4 to $12 \% \mathrm{wt}$. in steps of 4 in AA7075 alloy. They have adapted electromagnetic stir casting for producing the composites of interest. The composites are heat treated and have been studied for wear and friction behavior. The results of this work revealed that, hardness of heat treated composites has improved with dispersion of $\mathrm{Si}_{3} \mathrm{~N}_{4}$ in AA7075. Tensile strength and flexural strength of heat treated composites have increased with the addition of $8 \%$ wt. $\mathrm{Si}_{3} \mathrm{~N}_{4}$, but eventually decreased for $12 \%$ wt. $\mathrm{Si}_{3} \mathrm{~N}_{4}$ addition. An increased quantity of $\mathrm{Si}_{3} \mathrm{~N}_{4}$ in the matrix also has led to decrease in loss of wear and friction coefficient. Wear loss of composite having $12 \%$ wt. $\mathrm{Si}_{3} \mathrm{~N}_{4}$ with heat treatment has reduced up to $37.17 \%$ in comparison to heat treated AA7075 matrix. Friction coefficient of composite with 12 \%wt. $\mathrm{Si}_{3} \mathrm{~N}_{4}$ under heat treated condition has reduced up to $11.03 \%$ which is in comparison to pure heat treated AA7075. 
Table 8. Details of investigated parameters of AA7075 MMCs and the targeted parameter for improvement/application as taken up by the researchers.

\begin{tabular}{|c|c|c|c|}
\hline $\begin{array}{l}\text { Type of reinforcement/ } \\
\text { reinforcement combination }\end{array}$ & $\begin{array}{l}\text { Investigated parameters of } \\
\text { AA7075 MMCs }\end{array}$ & $\begin{array}{l}\text { Targeted improvement/ } \\
\text { application }\end{array}$ & References \\
\hline $\mathrm{SiC}$ & $\begin{array}{l}\text { Calorimetric study-heat } \\
\text { capacity }\left(\mathrm{C}_{\mathrm{p}}\right)\end{array}$ & $\begin{array}{l}\text { Thermal control system of } \\
\text { spacecraft }\end{array}$ & {$[50]$} \\
\hline $\mathrm{SiC}$ & Thermo-physical properties & $\begin{array}{l}\text { Critical aerospace application } \\
\text { material }\end{array}$ & {$[51]$} \\
\hline $\mathrm{SiC}$ & Characterization of MMC & $\begin{array}{l}\text { Improving performance of } \\
\text { MMCs }\end{array}$ & {$[52]$} \\
\hline $\mathrm{SiC}$ & $\begin{array}{l}\text { Machining parameters- } \\
\text { cutting speed, depth of cut, } \\
\text { and feed rate }\end{array}$ & $\begin{array}{l}\text { Surface roughness and tool wear } \\
\text { in turning }\end{array}$ & {$[53,54]$} \\
\hline $\mathrm{SiC}$ & Abrasive wear rate & $\begin{array}{l}\text { Improve tribological conditions } \\
\text { of MMCs }\end{array}$ & {$[55]$} \\
\hline $\mathrm{SiC}$ & $\begin{array}{l}\text { Mechanical and dry sliding } \\
\text { wear behavior }\end{array}$ & $\begin{array}{l}\text { Improve tribological conditions } \\
\text { of MMCs }\end{array}$ & {$[14]$} \\
\hline $\mathrm{SiC}$ & Characterization of MMC & $\begin{array}{l}\text { Improving performance of } \\
\text { MMCs }\end{array}$ & {$[17]$} \\
\hline $\mathrm{SiC}$ & Pin geometry in FSW & $\begin{array}{l}\text { Macro-micro structure, improve } \\
\text { mechanical properties of MMCs }\end{array}$ & {$[56]$} \\
\hline $\mathrm{SiC}$ & $\begin{array}{l}\text { Fatigue life, impact energy, } \\
\text { tensile strength }\end{array}$ & $\begin{array}{l}\text { Improve mechanical properties } \\
\text { by nano reinforcements }\end{array}$ & {$[57]$} \\
\hline $\mathrm{SiC}$ & $\begin{array}{l}\text { Approach: Ultrasonic-assisted } \\
\text { semisolid stirring }\end{array}$ & $\begin{array}{l}\text { Overcome the challenges in } \\
\text { dispersion of Nano sized } \\
\text { reinforcements }\end{array}$ & {$[58]$} \\
\hline $\mathrm{SiC}$ & $\begin{array}{l}\text { Processing maps approach for } \\
\text { studying hot compression } \\
\text { deformation mechanism and } \\
\text { effect of processing } \\
\text { parameters }\end{array}$ & $\begin{array}{l}\text { Improve properties of AMCs by } \\
\text { optimizing deformation process } \\
\text { parameters }\end{array}$ & {$[59]$} \\
\hline $\mathrm{SiC}$ & Tribological properties & $\begin{array}{l}\text { Understand tribological } \\
\text { conditions of MMCs }\end{array}$ & {$[60]$} \\
\hline $\mathrm{SiC}$ & $\begin{array}{l}\text { Mechanical and dry sliding } \\
\text { wear behavior }\end{array}$ & $\begin{array}{l}\text { Understand tribological } \\
\text { conditions of MMCs }\end{array}$ & {$[61]$} \\
\hline $\mathrm{SiC}$ & Mechanical characterization & $\begin{array}{l}\text { Study the influence of age } \\
\text { hardening }\end{array}$ & {$[62]$} \\
\hline $\mathrm{SiC}$ & $\begin{array}{l}\text { Rate of wear and friction } \\
\text { coefficient }\end{array}$ & $\begin{array}{l}\text { Understand wear characteristics } \\
\text { and develop potential } \\
\text { application for aircraft } \\
\text { components }\end{array}$ & {$[63,64]$} \\
\hline $\mathrm{SiC}$ & $\begin{array}{l}\text { Tool wear and mechanical } \\
\text { properties }\end{array}$ & Reduce tool wear in FSP & {$[65]$} \\
\hline $\mathrm{SiC}$ & $\begin{array}{l}\text { EDM and mechanical } \\
\text { properties }\end{array}$ & $\begin{array}{l}\text { Optimal wire EDM parameters } \\
\text { for machining of metal matrix } \\
\text { nano composites for aerospace } \\
\text { and automobile applications }\end{array}$ & {$[66]$} \\
\hline $\mathrm{SiC}$ & Surface roughness in drilling & $\begin{array}{l}\text { For best operational parameters, } \\
\text { materials parameters and } \\
\text { cutting tool selection }\end{array}$ & {$[34]$} \\
\hline $\mathrm{SiC}$ & Dry sliding wear behavior & $\begin{array}{l}\text { Improve the resistance to wear } \\
\text { of AA7075 }\end{array}$ & {$[67]$} \\
\hline $\mathrm{SiC} \& \mathrm{Al}_{2} \mathrm{O}_{3}$ & EDM & $\begin{array}{l}\text { Optimal wire EDM parameters } \\
\text { for machining of metal matrix } \\
\text { composites for aerospace } \\
\text { applications }\end{array}$ & {$[7]$} \\
\hline
\end{tabular}


Table 8. (continued).

\begin{tabular}{ll}
\hline $\begin{array}{l}\text { Type of reinforcement/ } \\
\text { reinforcement combination }\end{array}$ & $\begin{array}{l}\text { Investigated parameters of } \\
\text { AA7075 MMCs }\end{array}$ \\
\hline $\mathrm{SiC} \& \mathrm{Al}_{2} \mathrm{O}_{3}$ & Dry sliding wear behavior \\
$(\mathrm{SiC}+\mathrm{Ti})$ & $\begin{array}{l}\text { Effect of Ti reinforcement on } \\
\text { aging behavior and } \\
\text { mechanical properties }\end{array}$ \\
$\mathrm{SiC} \&$ Flyash & $\begin{array}{l}\text { Microstructural analysis and } \\
\text { examine grain structures }\end{array}$ \\
$\mathrm{SiC} \& \mathrm{Cr}$ & $\begin{array}{l}\text { Thermo-physical and } \\
\text { mechanical properties }\end{array}$ \\
$\mathrm{SiC} \& \mathrm{~B}_{4} \mathrm{C}$ & $\begin{array}{l}\text { Approach: Liquid pressing } \\
\text { process } \\
\text { Characterization of MMC }\end{array}$ \\
$\mathrm{SiC} \& \mathrm{ZrO}_{2}$ & $\begin{array}{l}\text { Effect of ceramics and solid } \\
\text { lubricants - Mechanical and } \\
\text { sliding wear characteristics }\end{array}$ \\
$\mathrm{SiC} \& \mathrm{Gr}_{\mathrm{SiC} \& \mathrm{~h}-\mathrm{BN}}$ & $\begin{array}{l}\text { Effect of ceramics and solid } \\
\text { lubricants - Mechanical and } \\
\text { sliding wear characteristics }\end{array}$ \\
$\mathrm{SiC} \& \mathrm{MoS}_{2}$ & Characterization of MMC \\
$\mathrm{SiC} \& \mathrm{Graphene}$ & Microstructural and \\
$\mathrm{SiC} \& \mathrm{TiB}_{2}$ & mechanical characterization \\
$\mathrm{Ag}-\mathrm{C} \mathrm{NP}$ & Machinability study \\
$\mathrm{CNT}$ &
\end{tabular}

\section{CNT}

\section{MWCNTs}

Gr

Gr

h-BN,

amorphous $\mathrm{B} \&\left(\mathrm{~B}_{4} \mathrm{C}+\mathrm{n}\right.$ -

$\mathrm{W})$

$$
\mathrm{Al}_{2} \mathrm{O}_{3}
$$

$\mathrm{Al}_{2} \mathrm{O}_{3}$

$\mathrm{Al}_{2} \mathrm{O}_{3}$

$\mathrm{Al}_{2} \mathrm{O}_{3}$

$\mathrm{Al}_{2} \mathrm{O}_{3}$
Precipitation hardening behavior

Mechanical, wear and machining characteristics

Microstructural and mechanical characterization

Dry sliding wear behavior

Dry sliding friction and wear properties

Impact strength

Mechanical and hightemperature tribological behavior

Grain refinement by high pressure torsion

Effect of heat treatment on microstructure and hardness

Approach: Squeeze casting for producing MMCs
Targeted improvement/ application

Improve the resistance to wear of AA7075

Improve the strength of AMC

Improve mechanical behavior

Improve the strength of AMC

Improve dynamic and ballistic properties

Improving performance of MMCs

Develop material for piston

Aerospace vehicles and racing automobiles

Improving performance of MMCs

Improving the properties of AA7075 by dispersing nano-Ag Overcome problems related to chip adhesion on rake face of cutting tool and subsequent formation of built-up-edge Effects of CNTs on precipitation hardening behavior of $\mathrm{Al}$ alloys

Understanding of the effects of MWCNTs

Structural applications

[5]

Improve the resistance to wear of AA7075

Improve the resistance to wear of AA7075

Eliminate primary discontinuities associated with MMCs

Material for cylinder piston ring system

Improving mechanical properties

Microstructure and overall properties of MMCs

Eliminate casting defects and to improve compressive strength for automotive brake discs and connecting rods 
Table 8. (continued).

\begin{tabular}{|c|c|c|c|}
\hline $\begin{array}{l}\text { Type of reinforcement/ } \\
\text { reinforcement combination }\end{array}$ & $\begin{array}{l}\text { Investigated parameters of } \\
\text { AA7075 MMCs }\end{array}$ & $\begin{array}{l}\text { Targeted improvement/ } \\
\text { application }\end{array}$ & References \\
\hline $\mathrm{Al}_{2} \mathrm{O}_{3}$ & Mechanical characterization & $\begin{array}{l}\text { Improve the properties of } \\
\text { MMCs }\end{array}$ & {$[29]$} \\
\hline $\mathrm{Al}_{2} \mathrm{O}_{3} \&$ graphite & $\begin{array}{l}\text { Mechanical properties and } \\
\text { dry sliding wear } \\
\text { characteristics }\end{array}$ & $\begin{array}{l}\text { Improve mechanical properties } \\
\text { and resistance to wear }\end{array}$ & {$[83]$} \\
\hline $\mathrm{Al}_{2} \mathrm{O}_{3} \& \mathrm{~h}-\mathrm{BN}$ & $\begin{array}{l}\text { To evaluate the effectiveness } \\
\text { of ultrasonic assisted } \\
\text { cavitation, molten salt } \\
\text { processing methods and } \mathrm{T}_{6} \\
\text { treatment and deep cryogenic } \\
\text { treatment }\end{array}$ & $\begin{array}{l}\text { Decide the effective processing } \\
\text { method and heat treatment } \\
\text { method which improves the } \\
\text { mechanical properties }\end{array}$ & {$[21]$} \\
\hline $\mathrm{Al}_{2} \mathrm{O}_{3} \&$ h-BN & $\begin{array}{l}\text { Dry sliding and abrasive wear } \\
\text { behavior }\end{array}$ & $\begin{array}{l}\text { Improve resistance to wear of } \\
\text { MMCs }\end{array}$ & [84] \\
\hline $\mathrm{Al}_{2} \mathrm{O}_{3} \&$ Flyash & Wear and tensile properties & $\begin{array}{l}\text { Improve the wear resistance and } \\
\text { tensile strength in comparison to } \\
\text { alloy }\end{array}$ & {$[28]$} \\
\hline $\mathrm{Al}_{2} \mathrm{O}_{3} \& \mathrm{SiC}$ & $\begin{array}{l}\text { Mechanical and wear } \\
\text { behavior }\end{array}$ & $\begin{array}{l}\text { Mechanical properties and wear } \\
\text { behavior of the MMCs for } \\
\text { structural applications }\end{array}$ & {$[30]$} \\
\hline $\mathrm{Al}_{2} \mathrm{O}_{3} \& \mathrm{SiC}$ & $\begin{array}{l}\text { Microstructure and } \\
\text { tribological characteristics }\end{array}$ & $\begin{array}{l}\text { Cylinder liners of automotive } \\
\text { and aircraft engines }\end{array}$ & {$[40]$} \\
\hline $\mathrm{TiO}_{2}$ & $\begin{array}{l}\text { Mechanical properties and } \\
\text { texture analysis }\end{array}$ & $\begin{array}{l}\text { Improve mechanical properties } \\
\text { of MMCs }\end{array}$ & {$[12]$} \\
\hline $\mathrm{B}_{4} \mathrm{C}$ & $\begin{array}{l}\text { Microstructure and } \\
\text { mechanical properties }\end{array}$ & $\begin{array}{l}\text { Effect of } \mathrm{B}_{4} \mathrm{C} \text { quantity on } \\
\text { microstructure and mechanical } \\
\text { properties }\end{array}$ & {$[9]$} \\
\hline $\mathrm{B}_{4} \mathrm{C}$ & $\begin{array}{l}\text { Parametric investigation (tool } \\
\text { rotational speed and } \\
\text { alteration in tool travel } \\
\text { direction) adapting FSP }\end{array}$ & $\begin{array}{l}\text { Improve the uniformity in } \\
\text { reinforcement distribution }\end{array}$ & {$[4]$} \\
\hline $\mathrm{B}_{4} \mathrm{C}$ & $\begin{array}{l}\text { Mechanical characterization } \\
\text { and effect of age hardening }\end{array}$ & Mechanical properties of MMCs & [62] \\
\hline $\mathrm{B}_{4} \mathrm{C}$ & $\begin{array}{l}\text { Microstructure and } \\
\text { mechanical properties }\end{array}$ & $\begin{array}{l}\text { Define properties under different } \\
\text { conditions }\end{array}$ & {$[85]$} \\
\hline $\mathrm{B}_{4} \mathrm{C}$ & $\begin{array}{l}\text { Elucidate the relationship } \\
\text { between the microstructure } \\
\text { and mechanical behavior of } \\
\text { submicron-grained, } \\
\text { precipitation strengthened Al- } \\
\text { based metal matrix } \\
\text { composites }\end{array}$ & $\begin{array}{l}\text { Distribution of reinforcement } \\
\text { particles, which had a high } \\
\text { number density }\end{array}$ & {$[86]$} \\
\hline $\mathrm{B}_{4} \mathrm{C}$ & $\begin{array}{l}\text { Plasma activated sintering } \\
\text { parameters on microstructure } \\
\text { and mechanical properties }\end{array}$ & $\begin{array}{l}\text { Understand densification } \\
\text { behavior and mechanical } \\
\text { properties }\end{array}$ & {$[8]$} \\
\hline $\begin{array}{l}\mathrm{B}_{4} \mathrm{C} \& \text { Coconut shell } \\
\text { flyash }\end{array}$ & Mechanical properties & $\begin{array}{l}\text { High strength MMCs for } \\
\text { automotive and aerospace } \\
\text { industries }\end{array}$ & {$[87]$} \\
\hline $\mathrm{B}_{4} \mathrm{C} \&$ Rice husk ash & Mechanical characterization & $\begin{array}{l}\text { Badminton shaft and defense } \\
\text { sectors for making rifles and } \\
\text { armors }\end{array}$ & {$[46]$} \\
\hline $\mathrm{B}_{4} \mathrm{C} \& \mathrm{MoS}_{2}$ & $\begin{array}{l}\text { Microstructure and dry } \\
\text { sliding wear }\end{array}$ & $\begin{array}{l}\text { Resistance to wear and friction } \\
\text { coefficient for automotive } \\
\text { applications }\end{array}$ & {$[25]$} \\
\hline
\end{tabular}


Table 8. (continued).

\begin{tabular}{|c|c|c|c|}
\hline $\begin{array}{l}\text { Type of reinforcement/ } \\
\text { reinforcement combination }\end{array}$ & $\begin{array}{l}\text { Investigated parameters of } \\
\text { AA7075 MMCs }\end{array}$ & $\begin{array}{l}\text { Targeted improvement/ } \\
\text { application }\end{array}$ & References \\
\hline $\mathrm{B}_{4} \mathrm{C} \&$ Flyash & Microstructure and hardness & $\begin{array}{l}\text { Automobile and aerospace } \\
\text { application }\end{array}$ & {$[26]$} \\
\hline $\mathrm{B}_{4} \mathrm{C} \&$ Flyash & $\begin{array}{l}\text { Mechanical and tribological } \\
\text { properties }\end{array}$ & $\begin{array}{l}\text { Sand cast brake rotor, } \\
\text { aeronautical and automobile } \\
\text { applications }\end{array}$ & {$[88]$} \\
\hline $\mathrm{B}_{4} \mathrm{C} \& \mathrm{BN}$ & $\begin{array}{l}\text { Mechanical properties and } \\
\text { influence of drilling } \\
\text { parameters }\end{array}$ & $\begin{array}{l}\text { Improving mechanical properties } \\
\text { and minimizing thrust force in } \\
\text { drilling }\end{array}$ & [89] \\
\hline $\mathrm{B}_{4} \mathrm{C} \& \mathrm{BN}$ & $\begin{array}{l}\text { Microstructure and } \\
\text { mechanical properties } \\
\text { characterization }\end{array}$ & Marine applications & {$[42]$} \\
\hline $\mathrm{B}_{4} \mathrm{C} \&$ Cow dung ash & $\begin{array}{l}\text { Micro structural } \\
\text { characteristics, mechanical } \\
\text { and tribological behaviors }\end{array}$ & Improving properties of MMCs & {$[33]$} \\
\hline $\mathrm{ZrO}_{2}$ & $\begin{array}{l}\text { Approach: effect on } \\
\text { distribution of reinforcement } \\
\text { due to the use of different } \\
\text { ball mills }\end{array}$ & $\begin{array}{l}\text { Improve the homogeneity of } \\
\text { dispersion of Nano particles }\end{array}$ & {$[90]$} \\
\hline $\mathrm{ZrB}_{2} \& \mathrm{hBN}$ & Dry sliding wear behavior & $\begin{array}{l}\text { Minimizing porosity and } \\
\text { improving wear performance }\end{array}$ & {$[39]$} \\
\hline $\mathrm{TiC}$ & Processing conditions in FSP & Distribution of reinforcements & {$[91]$} \\
\hline $\mathrm{TiC}$ & $\begin{array}{l}\text { Polarization studies using an } \\
\text { Electrochemical work Station }\end{array}$ & Corrosion characteristics & {$[92]$} \\
\hline $\mathrm{TiC}$ & $\begin{array}{l}\text { Microstructure, mechanical, } \\
\text { and tribological behavior }\end{array}$ & Aerospace applications & {$[27]$} \\
\hline $\mathrm{TiC}$ & $\begin{array}{l}\text { Coefficient of thermal } \\
\text { expansion }\end{array}$ & $\begin{array}{l}\text { Retard the thermal expansion of } \\
\text { AMMCs useful for aerospace } \\
\text { and automotive industries }\end{array}$ & {$[93]$} \\
\hline $\mathrm{TiC} \& \mathrm{~B}_{4} \mathrm{C}$ & Kerf characteristics in AJM & Improve machinability of MMCs & {$[94]$} \\
\hline $\mathrm{TiC} \& \mathrm{MoS}_{2}$ & Machining characteristics & Improved machinability & {$[95]$} \\
\hline $\mathrm{TiB}_{2}$ & $\begin{array}{l}\text { Mechanical characterization } \\
\text { and effect of age hardening }\end{array}$ & $\begin{array}{l}\text { Improve mechanical properties } \\
\text { of MMCs }\end{array}$ & {$[62]$} \\
\hline $\mathrm{TiB}_{2}$ & $\begin{array}{l}\text { High-temperature ductility } \\
\text { and fracture mechanisms }\end{array}$ & $\begin{array}{l}\text { Formability and fracture } \\
\text { mechanisms for elevated } \\
\text { temperature applications }\end{array}$ & {$[97]$} \\
\hline $\mathrm{TiB}_{2}$ & Tribological performance & Tribological performance & [98] \\
\hline $\mathrm{TiB}_{2}$ & $\begin{array}{l}\text { Particle dispersion and grain } \\
\text { refinement }\end{array}$ & $\begin{array}{l}\text { Microstructure and mechanical } \\
\text { properties }\end{array}$ & [99] \\
\hline $\mathrm{TiB}_{2} \& \mathrm{Gr}$ & Dry sliding wear behavior & $\begin{array}{l}\text { Optimizing the wear process } \\
\text { parameters }\end{array}$ & {$[24]$} \\
\hline $\mathrm{Si}_{3} \mathrm{~N}_{4}$ & Microhardness & $\begin{array}{l}\text { Study the improvement in } \\
\text { microhardness with quantity of } \\
\text { reinforcement }\end{array}$ & {$[100]$} \\
\hline $\mathrm{Si}_{3} \mathrm{~N}_{4}$ & Wear \& friction behavior & Brake disc and cam & [101] \\
\hline $\mathrm{Si}_{3} \mathrm{~N}_{4}$ & $\begin{array}{l}\text { Porosity studies and Spectro } \\
\text { analysis }\end{array}$ & $\begin{array}{l}\text { Reduce porosity and improve } \\
\text { properties of MMC }\end{array}$ & [102] \\
\hline $\mathrm{TaC}, \mathrm{Si}_{3} \mathrm{~N}_{4}, \mathrm{Ti}$ & $\begin{array}{l}\text { Microstructural, mechanical } \\
\text { and wear characteristics }\end{array}$ & $\begin{array}{l}\text { Understand the influence of } \\
\text { reinforcements }\end{array}$ & {$[35]$} \\
\hline $\mathrm{MoSi}_{2}$ & $\begin{array}{l}\text { Mechanical characterization } \\
\text { and dry sliding wear behavior }\end{array}$ & Improving properties of MMCs & {$[38]$} \\
\hline VN & $\begin{array}{l}\text { Microstructure, hardness, and } \\
\text { wear behavior }\end{array}$ & Engine piston & {$[103]$} \\
\hline
\end{tabular}


Variation of hardness, tensile strength and flexural strength as a function of quantity of reinforcements are shown in Figure 16.

Arun Kumar et al. [102] have investigated the effect of porosity on AA7075 alloy reinforced with $\mathrm{Si}_{3} \mathrm{~N}_{4}$ metal matrix composites through stir casting process. The results of their study reveals that the presence of porosity, consequently, decreases most of the mechanical properties of cast composites. Failures initiated from the pores within the matrix material, particle fracture and reinforcementmatrix interface are due to voids coalescence, reduction of ductility, and reduced composite cross-section. Table 4 gives an overview of the parameters of interest in the investigation carried out so far by individual researchers with a specific objective.

Bai et al. [103] have produced AA7075-15\%wt. VN composite by ball milling and hot press sintering. The experiments of this study indicated that there was a homogeneous distribution of VN in composite with $15 \%$ wt. VN in AA7075 matrix, with no noticeable agglomeration. The hardness of $15 \%$ wt. VN/7075 composite was $46.1 \%$ higher than the base alloy. Friction and wear test results indicated that the friction coefficient of $15 \% \mathrm{wt}$. VN/7075 composite decreased by $37.6 \%$ in comparison to AA7075 alloy.

Zhang et al. [104] have studied the influence of aging treatment on the microstructure and mechanical properties of CNTs/AA7075 composites. These researchers have fabricated composites by milling and hot press sintering. After aging treatment, the CNTs/7075 Al composites had the peak hardness of $151.4 \mathrm{HV}$, and the peak-aging time decreased from 14 to $10 \mathrm{~h}$ compared to AA7075. Also the CNTs/AA7075 composites exhibited a tensile strength of $558.3 \mathrm{MPa}$ and an elongation of $7.7 \%$.

\subsubsection{Summary of the properties of AA7075 composites based on other compounds}

The properties of MMCs based on other compounds are listed in Table 7.

Table 8 gives an overview of the parameters of interest in the investigation carried out so far by individual researchers with a specific objective.

\section{Conclusion}

The in depth review on the vast area of AA7075 grade aluminium alloy matrix composites presented here critically discusses famous solid state production methods like, powder metallurgy and friction stir processing/welding. Among these production methods modified powder metallurgy was extensively used for quality components. Paper also suggests various liquid state processing techniques like stir casting, squeeze casting, centrifugal casting and in-situ process for better dispersivity of reinforcements in the aluminium alloy matrix composites. The review indicates that the focus of investigation on AA7075 matrix composites is mainly revolving around the recent year innovation publication results with the addition of metal or ceramic compound reinforcements and possible heat treatments to elevate thermal and physical properties, machining characteristics and abrasive wear performance. Due to the possibility of improving the corrosion resistance, weldability in fusion welding and electrical properties by the addition of copper and magnesium the use is expanded to submarines, ships, prosthetic devices, aerospace, electronics applications, including military domain. It is observed that reinforcement hybridisation with one or more nano in addition to micro improves AA7075 composites properties drastically. The possible drawbacks of poor tribological properties, lower compression strength and low performance at elevated temperature is overcome by judicially introducing borides, nitrides and carbides in the matrix. The numerous work reported in recent years on hybridization with the addition of light and heavy organic/inorganic reinforcements diversified the application in wider sectors of tribology. Inspite of these possibilities to record its worthiness as possible competitor in materials field there is a need to focused research to overcome the existing limitations of poor ductility and toughness for exploring new application domains of this alloy matrix composites.

\section{References}

1. M. Singh, B.K. Prasad, D.P. Mondal, A.K. Jha, Dry sliding wear behaviour of an aluminium alloy-granite particle composite, Tribol. Int. 34 (2001) 557-567

2. S. Das, Y.L. Saraswathi, D.P. Mondal, Erosive-corrosive wear of aluminium alloy composites: influence of slurry composition and speed, Wear 261 (2006) 180-190

3. G.H. Wu, Z.Y. Dou, L.T. Jiang, J.H. Cao, Damping properties of aluminium matrix-flyash composites, Mater. Lett. 60 (2006) 2945-2948

4. H. Rana, V. Badheka, Elucidation of the role of rotation speed and stirring direction on AA7075- ${ }_{4} \mathrm{C}$ surface composites formulated by friction stir processing, Proc. Inst. Mech. Eng. L 233 (2019) 977-994

5. R. Deaquino-Lara, I. Estrada-Guel, G. Hinojosa-Ruiz, R. Flores-Campos, J.M. Herrera-Ramírez, R. Martínez-Sánchez, Synthesis of aluminium alloy 7075-graphite composites by milling processes and hot extrusion, J. Alloys Comp. 509 (2011) S284-S289

6. R. Deaquino-Lara, N. Soltani, A. Bahrami, E. GutiérrezCastañeda, E. García-Sánchez, M.A. Hernandez-Rodríguez, Tribological characterization of Al7075-graphite composites fabricated by mechanical alloying and hot extrusion, Mater. Des. 67 (2015) 224-231

7. S. Lal, S. Kumar, Z.A. Khan, A.N. Siddiquee, Wire electrical discharge machining of AA7075/ $\mathrm{SiC} / \mathrm{Al}_{2} \mathrm{O}_{3}$ hybrid composite fabricated by inert gas-assisted electromagnetic stir-casting process, J. Braz. Soc. Mech. Sci. Eng. 36 (2014) 335-346

8. C. Wu, P. Fang, G. Luo, F. Chen, Q. Shen, L. Zhang, E.J. Lavernia, Effect of plasma activated sintering parameters on microstructure and mechanical properties of $\mathrm{Al}-7075 / \mathrm{B}_{4} \mathrm{C}$ composites, J. Alloys Comp. 615 (2014) 276-282

9. Q. Shen, C. Wu, F. Luo, P. Fang, C. Li, Y. Wang, L. Zhang. Microstructure and mechanical properties of $\mathrm{Al}-7075 / \mathrm{B}_{4} \mathrm{C}$ composites fabricated by plasma activated sintering, J. Alloys Comp. 588 (2014) 265-270 
10. M. Bahrami, M.F. Nikoo, M.K.B. Givi, Microstructural and mechanical behaviors of nano-SiC-reinforced AA7075-O FSW joints prepared through two passes, Mater. Sci. Eng. A 626 (2015) 220-228

11. M.M. Sharma, C.W. Ziemian, T.J. Eden, Fatigue behavior of $\mathrm{SiC}$ particulate reinforced spray-formed $7 \mathrm{xxx}$ series Al-alloys, Mater. Des. 32 (2011) 4304-4309

12. S. Bera, S.G. Chowdhury, Y. Estrin, I. Manna, Mechanical properties of Al7075 alloy with nano-ceramic oxide dispersion synthesized by mechanical milling and consolidated by equal channel angular pressing, J. Alloys Comp. 548 (2013) 257-265

13. C. Wu, K. Ma, J. Wu, P. Fang, G. Luo, F. Chen, Q. Shen, L. Zhang, J.M. Schoenung, E.J. Lavernia, Influence of particle size and spatial distribution of $\mathrm{B}_{4} \mathrm{C}$ reinforcement on the microstructure and mechanical behavior of precipitation strengthened Al alloy matrix composites, Mater. Sci. Eng. A 675 (2016) 421-430

14. G.V. Kumar, C.S. Rao, N. Selvaraj, Mechanical and dry sliding wear behavior of Al7075 alloy-reinforced with $\mathrm{SiC}$ particles, J. Compos. Mater. 46 (2012) 1201-1209

15. Y.C. Lin, Y.Q. Jiang, X.M. Chen, D.X. Wen, H.M. Zhou, Effect of creep-aging on precipitates of 7075 aluminium alloy, Mater. Sci. Eng. A 588 (2013) 347-356

16. A.A. Sarhan, E. Zalnezhad, M. Hamdi, The influence of higher surface hardness on fretting fatigue life of hard anodized aerospace Al7075-T6 alloy, Mater. Sci. Eng. A 560 (2013) 377-387

17. R.K. Bhushan, S. Kumar, S. Das, Fabrication and characterization of $7075 \mathrm{Al}$ alloy reinforced with $\mathrm{SiC}$ particulates, Int. J. Adv. Manufactur. Technol. 65 (2013) 611-624

18. Y. Bai, Y. Guo, J. Li, Z. Yang, J. Tian, Effect of $\mathrm{Al}_{2} \mathrm{O}_{3}$ nanoparticle reinforcement on the mechanical and hightemperature tribological behavior of Al-7075 alloy, Proc. Inst. Mech. Eng. J 231 (2017) 900-909

19. X.L. Zou, Y.A. Hong, X.H. Chen, Evolution of second phases and mechanical properties of $7075 \mathrm{Al}$ alloy processed by solution heat treatment, Trans. Nonferrous Metals Soc. China 27 (2017) 2146-2155

20. J. Peng, X. Jin, Z. Xu, J. Zhang, Z. Cai, Z. Luo, M. Zhu, Study on the damage evolution of torsional fretting fatigue in a 7075 aluminium alloy, Wear 402 (2018) 160-168

21. C. Kannan, R. Ramanujam, Effectiveness evaluation of molten salt processing and ultrasonic cavitation techniques during the production of aluminium based hybrid nanocomposites-an experimental investigation, J. Alloys Comp. 751 (2018) 183-193

22. T.W. Lu, W.P. Chen, P. Wang, M.D. Mao, Y.X. Liu, Z.Q. Fu, Enhanced mechanical properties and thermo-physical properties of 7075Al hybrid composites reinforced by the mixture of Cr particles and $\mathrm{SiC}_{\mathrm{p}}$, J. Alloys Comp. 735 (2018) 1137-1144

23. R.M. Tekiyeh, M. Najafi, S. Shahraki, Machinability of AA7075- $\mathrm{T}_{6} /$ carbon nanotube surface composite fabricated by friction stir processing, Proc. Inst. Mech. Eng. E 233 (2019) 839-848

24. S. Sivasankaran, K.R. Ramkumar, F.A. Al-Mufadi, O.M. Irfan, Effect of $\mathrm{TiB}_{2} / \mathrm{Gr}$ hybrid reinforcements in $\mathrm{Al} 7075$ matrix on sliding wear behavior analyzed by response surface methodology, Metals Mater. Int. (2019) 1-7

25. S. Liu, Y. Wang, T. Muthuramalingam, G. Anbuchezhiyan, Effect of $\mathrm{B}_{4} \mathrm{C}$ and $\mathrm{MoS}_{22}$ reinforcement on micro structure and wear properties of aluminium hybrid composite for automotive applications, Compos. Part B: Eng. 176 (2019) 107329
26. M.K. Sahu, R.K. Sahu, Synthesis, microstructure and hardness of $\mathrm{Al} 7075 / \mathrm{B}_{4} \mathrm{C} / \mathrm{Fly}$-ash composite using stir casting method, Mater. Today: Proc. 27 (2020) 2401-2406

27. K.R. Ramkumar, S. Sivasankaran, F.A. Al-Mufadi, S. Siddharth, R. Raghu, Investigations on microstructure, mechanical, and tribological behaviour of AA7075-x wt.\% TiC composites for aerospace applications, Arch. Civil Mech. Eng. 19 (2019) 428-438

28. T.R. Prabhu, M. Murugan, B.P. Chiranth, R.K. Mishra, N. Rajini, P. Marimuthu, P.D. Babu, G. Suganya, Effects of dual-phase reinforcement particles $\left(\right.$ Flyash $\left.+\mathrm{Al}_{2} \mathrm{O}_{3}\right)$ on the wear and tensile properties of the AA7075 Al alloy based composites, J. Inst. Eng. (India): Ser. D 100 (2019) 29-35

29. S. Suresh, G.H. Gowd, M.D. Kumar, Experimental investigation on mechanical properties of $\mathrm{Al} 7075 / \mathrm{Al}_{2} \mathrm{O}_{3} /$ Mg NMMCs by stir casting method, Sādhanā. 44 (2019) 51

30. S. Suresh, G.H. Gowd, M.D. Kumar, Mechanical and wear behavior of $\mathrm{Al} 7075 / \mathrm{Al}_{2} \mathrm{O}_{3} / \mathrm{SiC} / \mathrm{mg}$ metal matrix nanocomposite by liquid state process, Adv. Compos. Hybrid Mater. 2 (2019) 530-539

31. S. Devaganesh, P.D. Kumar, N. Venkatesh, R. Balaji, Study on the mechanical and tribological performances of hybrid SiC-Al7075 metal matrix composites, J. Mater. Res. Technol. (2020)

32. S. Suresh, D. Sudhakara, B. Vinod, Investigation on mechanical, wear, and machining characteristics of Al7075/MWCNTs using the liquid state method, Adv. Compos. Hybrid Mater. (2020) 243-254

33. R. Manikandan, T.V. Arjunan, Studies on micro structural characteristics, mechanical and tribological behaviours of boron carbide and cow dung ash reinforced aluminium (Al7075) hybrid metal matrix composite, Compos. Part B: Eng. 183 (2020) 107668

34. F. Ficici, Evaluation of surface roughness in drilling particlereinforced composites, Adv. Compos. Lett. 29 (2020) $2633366 \times 20937711$

35. D.R. Smart, J.P. Kumar, C. Periasamy, Microstructural, mechanical and wear characteristics of AA7075/TaC/ $\mathrm{Si}_{3} \mathrm{~N}_{4} / \mathrm{Ti}$ based hybrid metal matrix composite material, Mater. Today: Proc. (2020)

36. K. Hemalatha, R. Ashwin, M. Santhanam, M.M. Riyaz, G. G. Sozhamannan, V.S. Venkatachalapthy. Experimental study on behaviour of $\mathrm{SiC}$ and Graphene on Al7075 hybrid metal matrix composite, Mater. Today: Proc. (2020)

37. S. Rajakumar, C. Muralidharan, V. Balasubramanian, Optimization of the friction-stir-welding process and tool parameters to attain a maximum tensile strength of AA7075- $\mathrm{T}_{6}$ aluminium alloy, Proc. Inst. Mech. Eng. B 224 (2010) 1175-1191

38. M.K. Manoj, V. Gadpale, Synthesis, characterization and dry sliding wear behaviour of $\mathrm{Al} 7075-\mathrm{MoS}_{2} \mathrm{i}_{2}$ composites prepared by stir casting technique, Trans. Indian Inst. Metals 72 (2019) 3153-3169

39. Loganathan P, Gnanavelbabu A, Rajkumar K, Influence of $\mathrm{ZrB}_{2} / \mathrm{hBN}$ particles on the wear behaviour of AA7075 composites fabricated through stir followed by squeeze cast technique, Proc. Inst. Mech. Eng. J (2020) 1350650120929501

40. K. Suganeswaran, R. Parameshwaran, T. Mohanraj, N. Radhika, Influence of secondary phase particles $\mathrm{Al}_{2} \mathrm{O}_{3} / \mathrm{SiC}$ on the microstructure and tribological characteristics of AA7075-based surface hybrid composites tailored using friction stir processing, Proc. Inst. Mech. Eng. C (2020) 0954406220932939 
41. J.M. Mistry, P.P. Gohil, An overview of diversified reinforcement on aluminium metal matrix composites: tribological aspects, Proc. Inst. Mech. Eng. J. 231 (2017) 399-421

42. N. Ramadoss, K. Pazhanivel, G. Anbuchezhiyan, Synthesis of $\mathrm{B}_{4} \mathrm{C}$ and $\mathrm{BN}$ reinforced Al7075 hybrid composites using stir casting method, J. Mater. Res. Technol. (2020)

43. M. Yildirim, D. Özyürek, M. Gürü, The effects of precipitate size on the hardness and wear behaviors of aged 7075 aluminium alloys produced by powder metallurgy route, Arab. J. Sci. Eng. 41 (2016) 4273-4281

44. J. Peng, X. Jin, Z. Xu, J. Zhang, Z. Cai, Z. Luo, M. Zhu, Study on the damage evolution of torsional fretting fatigue in a 7075 aluminium alloy, Wear 402 (2018) 160-168

45. Y. Li, D. Retraint, H. Xue, T. Gao, Z. Sun, Fatigue properties and cracking mechanisms of 7075 aluminium alloy under axial and torsional loadings, Proc. Struct. Integr. 19 (2019) 637-644

46. N. Verma, S.C. Vettivel, Characterization and experimental analysis of boron carbide and rice husk ash reinforced AA7075 aluminium alloy hybrid composite, J. Alloys Comp. $\mathbf{7 4 1}$ (2018) 981-998

47. A. Mazahery, M.O. Shabani, Nano-sized silicon carbide reinforced commercial casting aluminium alloy matrix: experimental and novel modelling evaluation, Powder Technol. 217 (2012) 558-565

48. M. Singh, O.P. Modi, D. Rupa, A.K. Jha, High stress abrasive wear behaviour of aluminium alloy-granite particle composite, Wear 233-235 (1999) 455-461

49. H. Lu, X. Wang, T. Zhang, Z. Cheng, Q. Fang, Design, fabrication, and properties of high damping metal matrix composites - a review, Materials 3 (2009) 958-977

50. B. Karthikeyan, S. Ramanathan, V. Ramakrishnan, A calorimetric study of $7075 \mathrm{Al} / \mathrm{SiC}_{\mathrm{p}}$ composites, Mater. Des. 31 (2010) S92-S95

51. B. Karthikeyan, S. Ramanathan, V. Ramakrishnan, Thermo physical property measurement of metal-matrix composites, Mater. Des. (2010) S82-S86

52. A. Ahmed, A.J. Neely, K. Shankar, P. Nolan, S. Moricca, T. Eddowes, Synthesis, tensile testing, and microstructural characterization of nanometric $\mathrm{SiC}$ particulate-reinforced $\mathrm{Al}$ 7075 matrix composites, Metall. Mater. Trans. A 41 (2010) $1582-1591$

53. R.K. Bhushan, S. Kumar, S. Das, Effect of machining parameters on surface roughness and tool wear for $7075 \mathrm{Al}$ alloy $\mathrm{SiC}$ composite, Int. J. Adv. Manufactur. Technol. 50 (2010) 459-469

54. S.Z. Chavoshi, Tool flank wear prediction in CNC turning of $7075 \mathrm{Al}$ alloy SiC composite, Product. Eng. 5 (2011) 37-47

55. S. Kumar, V. Balasubramanian, Effect of reinforcement size and volume fraction on the abrasive wear behaviour of AA7075 Al/ $\mathrm{SiC}_{\mathrm{p}} \mathrm{P} / \mathrm{M}$ composites - a statistical analysis, Tribol. Int. 43 (2010) 414-422

56. M. Bahrami, M.K. Givi, K. Dehghani, N. Parvin, On the role of pin geometry in microstructure and mechanical properties of AA7075/SiC nano-composite fabricated by friction stir welding technique, Mater. Des. 53 (2014) 519-527

57. M. Bahrami, N. Helmi, K. Dehghani, M.K. Givi, Exploring the effects of $\mathrm{SiC}$ reinforcement incorporation on mechanical properties of friction stir welded 7075 aluminium alloy: fatigue life, impact energy, tensile strength, Mater. Sci. Eng. A 595 (2014) 173-178
58. J. Jiang, Y. Wang, Microstructure and mechanical properties of the semisolid slurries and rheoformed component of nano-sized $\mathrm{SiC} / 7075$ aluminium matrix composite prepared by ultrasonic-assisted semisolid stirring, Mater. Sci. Eng. A 639 (2015) 350-358

59. H.D. Wu, H. Zhang, C.H. Shuang, D.F. Fu, Flow stress behavior and processing map of extruded $7075 \mathrm{Al} / \mathrm{SiC}$ particle reinforced composite prepared by spray deposition during hot compression, Trans. Nonferrous Metals Soc. China 25 (2015) 692-698

60. A. Nieto, H. Yang, L. Jiang, J.M. Schoenung, Reinforcement size effects on the abrasive wear of boron carbide reinforced aluminium composites, Wear 390 (2017) 228-235

61. T.R. Prabhu, Processing and properties evaluation of functionally continuous graded $7075 \mathrm{Al}$ alloy/SiC composites, Arch. Civil Mech. Eng. (2017) 20-31

62. D. Bandhu, A. Thakur, R. Purohit, R.K. Verma, K. Abhishek, Characterization \& evaluation of Al7075 MMCs reinforced with ceramic particulates and influence of age hardening on their tensile behavior, J. Mech. Sci. Technol. 32 (2018) 3123-3128

63. S. Suresh, G.H. Gowd, M.D. Kumar, Wear behaviour of Al $7075 / \mathrm{SiC} / \mathrm{Mg}$ metal matrix nano composite by liquid state process, Adv. Compos. Hybrid Mater. 1 (2018) 819-825

64. S. Suresh, G.H. Gowd, M.D. Kumar, Tribological behavior of $\mathrm{Al} 7075 / \mathrm{SiC}$ metal matrix nano-composite by stir casting method, J. Inst. Eng. (India): Ser. D 100 (2019) 97-103

65. N.M. Ramezani, B. Davoodi, M. Aberoumand, M.R. Hajideh, Assessment of tool wear and mechanical properties of $\mathrm{Al} 7075$ nanocomposite in friction stir processing (FSP), J. Braz. Soc. Mech. Sci. Eng. 41 (2019) 182

66. S. Suresh, D. Sudhakara, Investigations on wire electric discharge machining and mechanical behavior of Al 7075/ nano-SiC composites, J. Inst. Eng. (India): Ser. D 100 (2019) 217-227

67. K.K. Singh, S. Singh, A.K. Shrivastava, Comparison of wear and friction behavior of aluminium matrix alloy (Al 7075) and silicon carbide based aluminium metal matrix composite under dry condition at different sliding distance, Mater. Today: Proc. 4 (2017) 8960-8970

68. R. AM, M. Kaleemulla, S. Doddamani, B. KN, Material characterization of $\mathrm{SiC}$ and $\mathrm{Al}_{2} \mathrm{O}_{3}$-reinforced hybrid aluminium metal matrix composites on wear behavior, Adv. Compos. Lett. 28 (2019) 0963693519856356

69. Y. Liu, W. Chen, C. Yang, D. Zhu, Y. Li, Effects of metallic $\mathrm{Ti}$ particles on the aging behavior and the influenced mechanical properties of squeeze-cast $\left(\mathrm{SiC}_{\mathrm{p}}+\right.$ Ti)/7075Al hybrid composites, Mater. Sci. Eng. A 620 (2015) 190-197

70. U.R. Kanth, P.S. Rao, M.G. Krishna, Mechanical behaviour of flyash/SiC particles reinforced Al-Zn alloy-based metal matrix composites fabricated by stir casting method, J. Mater. Res. Technol. 8 (2019) 737-744

71. M.C. Jo, J.H. Choi, J. Yoo, D. Lee, S. Shin, I. Jo, S.K. Lee, S. Lee, Novel dynamic compressive and ballistic properties in 7075-T6 Al-matrix hybrid composite reinforced with $\mathrm{SiC}$ and $\mathrm{B}_{4} \mathrm{C}$ particulates, Compos. Part B: Eng. 174 (2019) 107041

72. V.B. Nathan, R. Soundararajan, C.B. Abraham, Evaluation of mechanical and metallurgical properties on aluminium hybrid metal matrix composites, Mater. Today: Proc. 18 (2019) 2520-2529 
73. S. Devaganesh, P.D. Kumar, N. Venkatesh, R. Balaji, Study on the mechanical and tribological performances of hybrid SiC-Al7075 metal matrix composites, J. Mater. Res. Technol. (2020)

74. A. Bhowmik, D. Dey, A. Biswas, Comparative study of microstructure, physical and mechanical characterization of $\mathrm{SiC} / \mathrm{TiB}_{2}$ reinforced aluminium matrix composite, Silicon (2020) 1-8

75. R. Flores-Campos, D.C. Mendoza-Ruiz, P. Amézaga-Madrid, I. Estrada-Guel, M. Miki-Yoshida, J.M. Herrera-Ramírez, R. Martínez-Sánchez, Microstructural and mechanical characterization in 7075 aluminium alloy reinforced by silver nanoparticles dispersion, J. Alloys Comp. 495 (2010) 394-398

76. H.B. Zhang, B. Wang, Y.T. Zhang, Y. Li, J.L. He, Y.F. Zhang, Influence of aging treatment on the microstructure and mechanical properties of CNTs/7075 Al composites, J. Alloys Comp. 814 (2020) 152357

77. R. Deaquino-Lara, N. Soltani, A. Bahrami, E. GutiérrezCastañeda, E. García-Sánchez, M.A. Hernandez-Rodríguez, Tribological characterization of Al7075-graphite composites fabricated by mechanical alloying and hot extrusion, Mater. Des. 67 (2015) 224-231

78. M.V. Gorshenkov, S.D. Kaloshkin, V.V. Tcherdyntsev, V.D. Danilov, V.N. Gulbin. Dry sliding friction of Al-based composites reinforced with various boron-containing particles, J. Alloys Comp. 536 (2012) S126-A129

79. I.B. Deshmanya, G.K. Purohit, Development of models for predicting impact strength of $\mathrm{Al} 7075 / \mathrm{Al}_{2} \mathrm{O}_{3}$ composites produced by stir-casting, J. Compos. Mater. 46 (2012) 32473253

80. S. Sabbaghianrad, T.G. Langdon, Developing superplasticity in an aluminium matrix composite processed by highpressure torsion, Mater. Sci. Eng. A 655 (2016) 36-43

81. P.X. Zhang, H. Yan, W. Liu, X.L. Zou, B.B. Tang, Effect of T6 heat treatment on microstructure and hardness of nanosized $\mathrm{Al}_{2} \mathrm{O}_{3}$ reinforced 7075 aluminium matrix composites, Metals 9 (2019) 44

82. R. Muraliraja, R. Arunachalam, I. Al-Fori, M. Al-Maharbi, S. Piya, Development of alumina reinforced aluminium metal matrix composite with enhanced compressive strength through squeeze casting process, Proc. Inst. Mech. Eng. L 233 (2019) 307-314

83. A. Baradeswaran, A.E. Perumal, Study on mechanical and wear properties of $\mathrm{Al} 7075 / \mathrm{Al}_{2} \mathrm{O}_{3}$ /graphite hybrid composites, Compos. Part B: Eng. 56 (2014) 464-471

84. S. Rakshath, B. Suresha, R.S. Kumar, I. Saravanan, Dry sliding and abrasive wear behaviour of Al-7075 reinforced with alumina and boron nitride particulates, Mater. Today: Proc. 22 (2020) 619-626

85. A. Javdani, A.H. Daei-Sorkhabi, Microstructural and mechanical behavior of blended powder semisolid formed $\mathrm{Al} 7075 / \mathrm{B}_{4} \mathrm{C}$ composites under different experimental conditions, Trans. Nonferrous Metals Soc. China 28 (2018) 1298-310

86. C. Wu, R. Shi, G. Luo, J. Zhang, Q. Shen, Z. Gan, J. Liu, L. Zhang, Influence of particulate $\mathrm{B}_{4} \mathrm{C}$ with high weight fraction on microstructure and mechanical behavior of an Al-based metal matrix composite, J. Alloys Comp. 789 (2019) 825-833
87. B. Subramaniam, B. Natarajan, B. Kaliyaperumal, S.J. Chelladurai, Investigation on mechanical properties of aluminium 7075-boron carbide-coconut shell flyash reinforced hybrid metal matrix composites, China Foundry $\mathbf{1 5}$ (2018) 449-456

88. T.P. Reddy, S.J. Kishore, P.C. Theja, P.P. Rao, Development and wear behavior investigation on aluminum-7075/ $\mathrm{B}_{4} \mathrm{C} /$ flyash metal matrix composites, Adv. Compos. Hybrid Mater. (2020) 1-1

89. V.V. Kumar, K. Raja, V.C. Sekar, T. Ramkumar, Thrust force evaluation and microstructure characterization of hybrid composites $\left(\mathrm{Al} 7075 / \mathrm{B}_{4} \mathrm{C} / \mathrm{BN}\right)$ processed by conventional casting technique, J. Braz. Soc. Mech. Sci. Eng. 41 (2019) 228

90. S.E. Hernández-Martinez, J.J. Cruz-Rivera, C.G. GarayReyes, R. Martínez-Sánchez, I. Estrada-Guel, J.L. Hernández-Rivera, Comparative study of synthesis of AA7075- $\mathrm{ZrO}_{2}$ metal matrix composite by different mills, J. Alloys Comp. 643 (2015) S107-S113

91. D. Verdera, P. Rey, F. García, R. Saldaña, manufacturing a surface composite material made of nanoceramic particles of $\mathrm{TiC}$ and aluminium alloy 7075 by means of friction stir processing, InFriction Stir Welding and Processing VIII (2015) 199-206

92. S. Kumar, A. Kumar, C. Vanitha, Corrosion behaviour of Al 7075/ TiC composites processed through friction stir processing, Mater. Today: Proc. 15 (2019) 21-29

93. J.T. Wang, L. Xie, Z.G. Wang, H. Gu, K.Y. Luo, Y.L. Lu, M.T. He, M.Z. Ge, Influence of laser shock peening on the coefficient of thermal expansion of $\mathrm{Al}$ (7075)-based hybrid composites, J. Alloys Comp. 844 (2020) 156088

94. K.S. Sasikumar, K.P. Arulshri, K. Ponappa, M. Uthayakumar, A study on kerf characteristics of hybrid aluminium 7075 metal matrix composites machined using abrasive water jet machining technology, Proc. Inst. Mech. Eng. B 232 (2018) 690-704

95. A. Dhulipalla, B.U. Kumar, V. Akhil, J. Zhang, Z. Lu, H.Y. Park, T.G. Jung, J. Zhang, Synthesis and machining characteristics of novel $\mathrm{TiC}$ ceramic and $\mathrm{MoS}_{22}$ soft particulate reinforced aluminium alloy 7075 matrix composites, Manufactur. Lett. (2020)

96. B. Yang, G. Gan, L. Yang, M. Sun, H. Zhang, Z.Z. Fang, Microstructural characterization and wear behavior of in situ $\mathrm{TiC} / 7075$ composites synthesized by displacement reactions and spray forming, Mater. Sci. Eng. A 528 (2011) 549-555

97. H. Wang, H. Zhang, Z. Cui, Z. Chen, D. Chen, H. Wang, Investigation on the high-temperature ductility and fracture mechanisms of an in-situ particle reinforced $\mathrm{Al}$ matrix composite $7075 \mathrm{Al} / \mathrm{TiB}_{2}$, Mater. Sci. Eng. A 764 (2019) 138263

98. S. Pan, T. Saso, N. Yu, M Sokoluk, G. Yao, N. Umehara, X. $\mathrm{Li}$, New study on tribological performance of AA7075- $\mathrm{TiB}_{2}$ nanocomposites, Tribol. Int. 152 (2020) 106565

99. S. Zhao, H. Zhang, Z. Cui, D. Chen, Z. Chen, Particle dispersion and grain refinement of in-situ $\mathrm{TiB}_{2}$ particle reinforced $7075 \mathrm{Al}$ composite processed by elliptical crosssection torsion extrusion, J. Alloys Comp. (2020) 155136

100. M.I. Haq, A. Anand, Microhardness studies on stir cast AA7075- $\mathrm{Si}_{3} \mathrm{~N}_{4}$ based composites, Mater. Today: Proc. 5 (2018) 19916-19922 
101. J.M. Mistry, P.P. Gohil, Experimental investigations on wear and friction behaviour of $\mathrm{Si}_{3} \mathrm{~N}_{4} \mathrm{p}$ reinforced heattreated aluminium matrix composites produced using electromagnetic stir casting process, Compos. Part B: Eng. 161 (2019) 190-204

102. S.A. Kumar, J.H. Vignesh, S.P. Joshua, Investigating the effect of porosity on aluminium 7075 alloy reinforced with silicon nitride $\left(\mathrm{Si}_{3} \mathrm{~N}_{4}\right)$ metal matrix composites through stir casting process, Mater. Today: Proc. (2020)

103. Y. Bai, M. Liu, J. Li, Y. Guo, Tribofilm formation on the $\mathrm{VN} / 7075$ composite surface under sulfur-containing boundary lubrication, Proc. Inst. Mech. Eng. J. (2020) 1350650120930165

104. H.B. Zhang, B. Wang, Y.T. Zhang, Y. Li, J. He, Y.F. Zhang, Influence of aging treatment on the microstructure and mechanical properties of CNTs/7075 Al composites, J. Alloys Comp. 814 (2020) 152357
105. H. Lee, J.H. Choi, M.C. Jo, D. Lee, S. Shin, I. Jo, S.K. Lee, S. Lee, Effects of $\mathrm{SiC}$ particulate size on dynamic compressive properties in 7075-T6 $\mathrm{Al}_{-} \mathrm{SiC}_{\mathrm{p}}$ composites, Mater. Sci. Eng. A 738 (2018) 412-419

106. R. Liu, C. Wu, J. Zhang, G. Luo, Q. Shen, L. Zhang, Microstructure and mechanical behaviors of the ultrafine grained AA7075 $/ \mathrm{B}_{4} \mathrm{C}$ composites synthesized via one-step consolidation, J. Alloys Comp. 748 (2018) 737-744

107. U.R. Kanth, P.S. Rao, M.G. Krishna, Mechanical behaviour of flyash/SiC particles reinforced Al-Zn alloy-based metal matrix composites fabricated by stir casting method, J. Mater. Res. Technol. 8 (2019) 737-744

108. N. Gangil, S. Maheshwari, A.N. Siddiquee, N.Z. Khan, X. Chen, S. Konovalov, Microstructural characterization and tribological behaviour of surface composites fabricated on AA7050-T7451 alloy via friction stir processing, Proc. Inst. Mech. Eng. J 19 (2020) 1350650120950867

Cite this article as: Sowrabh B.S., Gurumurthy B.M., Shivaprakash Y.M., Sathya Shankara Sharma, Reinforcements, production techniques and property analysis of AA7075 matrix composites - a critical review, Manufacturing Rev. 8, 31 (2021) 